\title{
Leach and EP Toxicity Tests on Grouted Waste From Tank 106-AN
}
R. J. Serne
V. L. LeGore
W. J. Martin
C. W. Lindenmeier
R. O. Lokken
P. F. C. Martin

September 1989

Prepared for the U.S. Department of Energy under Contract DE-AC06-76RLO 1830

Pacific Northwest Laboratory Operated for the U.S. Department of Energy by Battelle Memorial Institute 


\title{
DISCLAIMER
}

This program was prepared as an account of work sponsored by an agency of the United States Government. Neither the United States Government nor any agency thereof, nor Battelle Mernorial Institute, nor any or their employees, makes any warranty, expressed or implied, or assumes any legal liability or responsibility for the accuracy, completeness, or usefulness of any information, apparatus, product, or process disclosed, or represents that its use would not iniringe privalely owned rights. Reference herein to any specific commercial product, process, or service by trade name, trademark, manufacturer, or otherwise, does not necessarily constitute or imply its endorsement, recommendation, or favoring by the United States Government of any agency thereof, or Battelle Memorial Institute. The views and opinions of authors expressed herein do not necessarily state or reflect those of the United States Government or any agency thereof.

\author{
PACIFIC NORTHWEST LABORATORY \\ operated by \\ BATTELLE MEMORIAL INSTITUTE \\ for the \\ UNITED STATES DEPARTMENT OF ENERGY \\ under Contract DE-ACO6-76RLO 1830
}

Printed in the United States of America

Available to DOE and DOE contractors from the

Office of Scientific and Technical Intormation, P.O. Box 62, Oak Ridge, TN 37831; prices available from $(615) 576-8401$. FTS 626-8401.

\begin{tabular}{l} 
Available to the public trom the National Technical In \\
U.S. Department of Commerce, 5285 Port Royal Rd.. Sp \\
NTis Price Codes, Microfiche A01 \\
\multicolumn{2}{c}{ Printed Copy } \\
$\qquad \begin{array}{cc}\text { Pages } & \text { Codes } \\
001-025 & \text { A02 } \\
026-050 & \text { A03 } \\
051-075 & \text { A04 } \\
076-100 & \text { A05 } \\
101-125 & \text { A06 } \\
126-150 & \text { A07 } \\
151-175 & \text { A08 } \\
176-200 & \text { A09 } \\
201-225 & \text { A10 } \\
226-250 & \text { AT1 } \\
251-275 & \text { A12 } \\
276-300 & \text { A1.3 }\end{array}$
\end{tabular}


HANFORD GROUT TECHNOLOGY PROGRAM

LEACH AND EP TOXICITY. TESTS ON GROUTED WASTE FROM TANK 106-AN
R. J. Serne
V. L. LeGore
W. J. Martin
C. W. Lindenmejer
R. 0. Lokken
P. F. C. Martin

September 1989

Prepared for

the U.S. Department of Energy

under Contract DE-AC06-76RLO 1830

Pacific Northwest Laboratory

Richland, Washington 99352 



\section{SUMMARY}

Pacific Northwest Laboratory is conducting laboratory experiments to produce leach rate data for various waste species that will be contained in grout at Hanford. In the work reported here, grout made from Tank 106-AN liquid waste was used to produce empirical leach rate data for several radio-

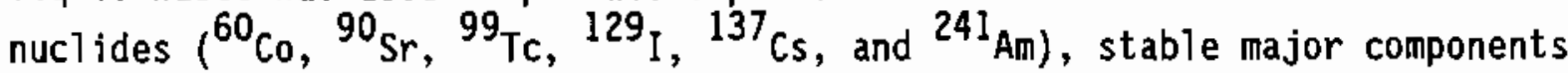
$\left(\mathrm{NO}_{3}^{-}, \mathrm{NO}_{2}^{-}, \mathrm{F}, \mathrm{Cl}\right.$, and $\mathrm{Na}$ ), and trace metals $(\mathrm{Cr}, \mathrm{Mo}$, and $\mathrm{Ni})$. Two types of tests were used to produce leach rate data: an intermittent replacement leach test (ANS 16.1 leach test) and a static leach test. Measured effective diffusivities of key species are as follows: 4 to $6 \times 10^{-8} \mathrm{~cm}^{2} / \mathrm{sec}$ for ${ }^{99} \mathrm{Tc}$, 3 to $7 \times 10^{-8} \mathrm{~cm}^{2} / \mathrm{sec}$ for ${ }^{129} \mathrm{I}, 4$ to $6 \times 10^{-9} \mathrm{~cm}^{2} / \mathrm{sec}$ for nitrate, and 6 to $7 \times 10^{-9}$ $\mathrm{cm}^{2} / \mathrm{sec}$ for nitrite. The leach indices of all species studied are above (more favorable than) the waste form criteria. The leach indices for ${ }^{99}$ Tc and ${ }^{129}{ }_{I}$ are $7.4 \pm 1.2$ and $7.6 \pm 0.4$, respectively, and are being further investigated in continuing studies of double-she11 slurry feed grouts. An Extraction Procedure (EP) toxicity test was a]so conducted and the grouted waste is considered nontoxic per this test protocol. 


\section{ACKNOWLEDGMENTS}

This study was funded by Westinghouse Hanford Company (WHC) as part of the Grout Disposal Program. Completion of the document fulfills Milestone 88-02 (I) of the FY 1988 statement of work. We wish to acknowledge the program direction, support, and peer review efforts of J. M. Allison, T. B. Bergman, W. G. Richmond, and G. F. Williamson from WHC and D. H. Mitche11 from Pacific Northwest Laboratory (PNL).

We wish to thank W. G. Richmond (WHC) for obtaining the Tank 106-AN liquid waste and results of various measurements, and the following PNL staff for analytical support: C. W. Thomas (wet chemical separations and radionuclide counting); and F. T. Hara, D. E. Rinehart, D. L. Widrig and L. M. Padilla (chemical analysis of leachates by ICP and IC). We wish to thank E. A. Fairweather for typing the original manuscript. 



\section{CONTENTS}

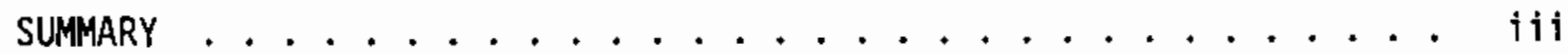

ACKNOWLEDGMENTS ...................

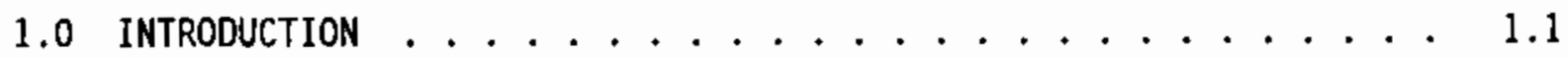

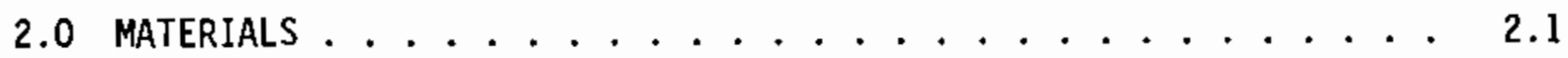

2.1 TANK 106 -AN LIQUID WASTE . . . . . . . . . . . 2.1

2.2 GROUT PRODUCTION . . . . . . . . . . . . . 2.3

2.3 HANFORD GROUND WATER . . . . . . . . . . . . . . 2.6

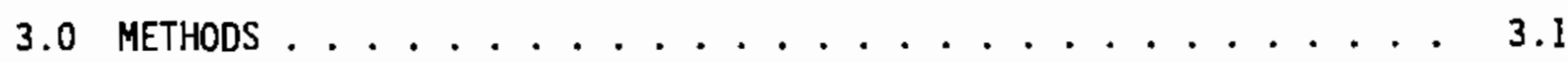

3.1 ANS 16.1 LEACH TESTS . . . . . . . . . . . 3.2

3.2 STATIC LEACh TESTS . . . . . . . . . . . . . . . 3.3

3.3 EXTRACTION PROCEDURE TOXICITY TESTS . . . . . . . . 3.4

4.0 RESULTS AND DISCUSSION . . . . . . . . . . . . . 4.1

4.1 LEACHATE CHEMISTRY FOR ANS 16.1 AND STATIC
LEACH TESTS . . . . . . . . . . . . . . . . 4.1

4.2 LEACH RATES OF SELECTED SPECIES . . . . . . . . . . 4.8

4.3 RESULTS OF EXTRACTION PROCEDURE TOXICITY TEST . . . . . 4.15

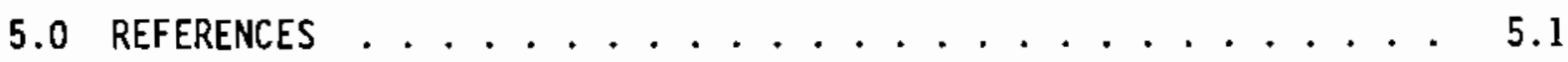

APPENDIX A - CHEMICAL COMPOSITIONS OF LEACHATES . . . . . . A.

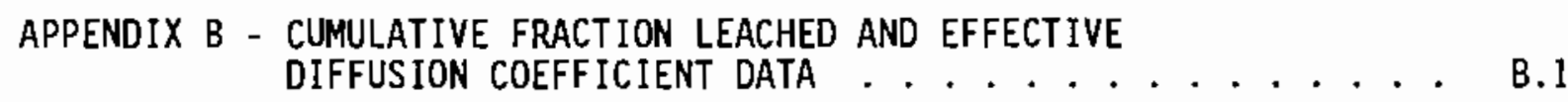

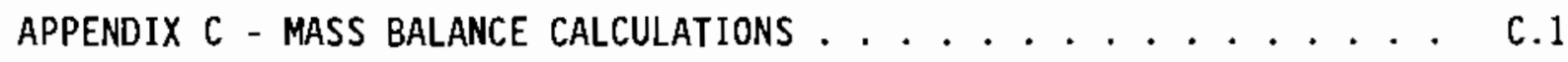

APPENDIX D - RAW DATA FOR RADIONUCLIDE COUNTING . . . . . . D.

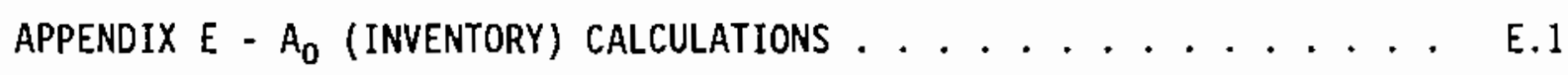





\section{FIGURES}

2.1 System Used to Mix Sma11 Batches of Radioactive Grout . . . . . . 2.4

2.2 Rheogram for Tank 106-AN Grout . . . . . . . . . . . . . 2.6

4.1 $\mathrm{pH}$ Values for ANS 16.1 and Static Leachates from Intact Grout Cylinders . . . . . . . . . . . . . . . 4.1

4.2 Ca Concentration for ANS 16.1 and Static Leachates from Intact Grout Cylinders ................ . 4.2

4.3 Mg Concentration for ANS 16.1 and Static Leachates from Intact Grout Cylinders . . . . . . . . . . . . . . . 4.4

4.4 Na Concentration for ANS 16.1 and Static Leachates from Intact Grout Cylinders . . . . . . . . . . . . . . . 4.4

4.5 $K$ Concentration for ANS 16.1 and Static Leachates from Intact Grout Cylinders . . . . . . . . . . . . . . 4.5

4.6 $\mathrm{NO}_{3}$ Concentration in ANS 16.1 and Static Leachates from Intact Grout Cylinders . . . . . . . . . . . . . 4.8

4.7 $\mathrm{NO}_{2}$ Concentration in ANS 16.1 and Static Leachates from Intact Grout Cylinders . . . . . . . . . . . . 4 4.9 


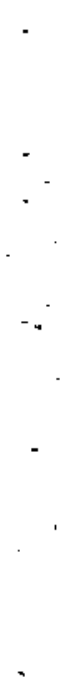

$\checkmark$ 


\section{$\underline{\text { TABLES }}$}

2.1 Comparison Between PNL and WHC Chemical Analyses of

Composite Samples of Tank 106-AN Waste .......... 2.2

2.2 Comparison Between PNL and WHC Radionuclide Analyses of Composite Samples of Tank 106-AN Waste ......... 2.3

2.3 Chemical Composition of Water from a Hanford Well . . . . . 2.8

3.1 Sampling Schedule for ANS 16.1 Leach Test and Static Leach Test . . . . . . . . . . . . . . 3.1

3.2 Tests Conducted on 106-AN Grout Specimens and Dimensions of Right cylinders . . . . . . . . . . . . . 3.2

4.1 Cumulative $D_{\mathrm{e}}$ Values for Species Leaching from Tank

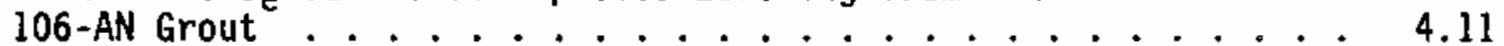

4.2 Comparison of ORNL and PNL Leach Data . . . . . . . . . 4.14

4.3 Extraction Procedure Toxicity Results for Radioactive Tank 106-AN Grout ................. 4.16 


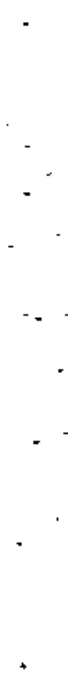




\subsection{INTRODUCTION}

A U.S. Department of Energy (DOE) program is under way to construct and operate a Grout Treatment Facility (GTF) at the Hanford Site near Richland, Washington, for disposing of the low-level fraction of liquid double-shell tank wastes. The wastes will be immobitized and disposed as solidified grout. This program is funded through DOE and is managed by Westinghouse Hanford Company (WHC), with technical support from Dak Ridge National Laboratory (ORNL) and Pacific Northwest Laboratory (PNL). (a) The GTF produced grout containing phosphate-su]fate waste (PSW) during 1988/1989.

At the GTF, low-level liquid wastes are mixed with blends of groutforming solids (Portiand cement, fly ash, clays, and other components) to produce a slurry. This slurry is pumped to near-surface disposal sites (engineered vaults), where the grout will harden and cure to form large, solid monoliths of imnobilized waste. As part of the program to demonstrate the acceptability of grout as a final disposal method, performance assessment studies are being conducted. These studies yield computer-generated predictions that are used to assess the impact of the grout disposal method on long-term public health and safety.

An assessment of the long-term performance of the grout disposal system requires data on the effective diffusivity of species within the grout. This document reports progress on laboratory experiments that are producing empirical diffusion data for a particular grouted waste stream (i.e., grouted waste from Tank 106-AN). Empirical leach rates are being produced for several

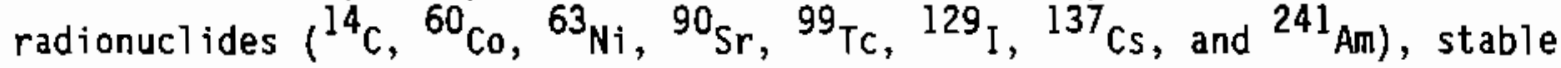
major components ( $\mathrm{NO}_{3}^{-}, \mathrm{NO}_{2}^{-}, \mathrm{F}, \mathrm{Cl}$, and $\mathrm{Na}$ ), and trace metals ( $\mathrm{Cr}$, Mo, and $\mathrm{Ni}$. The effective diffusivities are direct inputs to the performance assessment models used to forecast potential environmental impacts. In addition, the report presents results from an extraction procedure (EP) toxicity test, which is a regulatory test used for waste classification.

(a) Pacific Northwest Laboratory is operated by Battelle Memorial Institute for the U.S. Department of Energy under Contract DE-ACO6-76RLO 1830. 
This report is divided into sections that discuss materials used in leaching tests, test methods, and laboratory test results and conclusions. Appendices $A$ through $E$ contain the raw data used to support the analyses. 


\subsection{MATERIALS}

Details on the Tank 106-AN waste, grout production, and Hanford groundwater chemistry are described in this section.

\subsection{IANK 106-AN LIOUID WASTE}

Westinghouse Hanford Company provided four lead-shielded pigs that contained plastic bottles of liquid waste. To create a composite sample of waste, a beaker was placed on a stirrer/hot plate and the contents of the bottle from one pig were poured into the beaker. Visual inspection showed a yellowish, clear fluid with no suspended solids. No residual precipitate was present in the bottle. Once the solution in the beaker reached $>35^{\circ} \mathrm{C}$, a second pig was opened and the contents of its bottle were added to the beaker. The procedure was repeated for the remaining bottles. At no time did the mixture show signs of precipitation or cloudiness. Because the liquid waste in each bottle was radioactive, contents were added to the beaker without measuring volumes. However, WHC indicated that each bottle contained about the same volume (i.e., $60 \pm 10 \mathrm{~mL}$ ). All sampling of the composite liquid waste sample was performed at temperatures of $50^{\circ} \mathrm{C}$ to $60^{\circ} \mathrm{C}$. Chemical and radionuclide analyses were performed using the same procedures that were used to analyze grout leachates (see Section 3.0). The ion chromatography (IC) measurements were performed on a solution consisting of 1-part waste to 25-parts distilled water on October 29, 1987. The inductively coupled plasma (ICP) measurements were performed on a 1-part waste to 10-parts acid ditution on November 9, 1987. The radionuclide determinations were performed on a 1-part waste to 10-parts acid diTution over the period December 1 to I5, 1987.

Tables 2.1 and 2.2 compare the PNL measurements with results provided by WHC. The PNL and WHC composite samples were prepared separately and do not represent duplicate samples. 
TABLE 2.1. Comparison Between PNL and WHC Chemical Analyses of Composite Samples of Tank 106-AN Waste

\begin{tabular}{|c|c|c|}
\hline \multirow{2}{*}{$\begin{array}{c}\text { Waste } \\
\text { Constituents } \\
\end{array}$} & \multicolumn{2}{|c|}{ Chemical Results (mq/L) } \\
\hline & PNL & WHC \\
\hline A1 & 10,800 & 12,465 \\
\hline B & 28.6 & 18.2 \\
\hline $\mathrm{Ca}$ & 70 & 85 \\
\hline $\mathrm{Cr}$ & 662 & 832 \\
\hline $\mathrm{Cu}$ & -- & 1.5 \\
\hline K & 31 & 32 \\
\hline $\mathrm{Na}$ & 93,800 & 121,600 \\
\hline $\mathrm{Ni}$ & 27 & $(5)^{(a)}$ \\
\hline Si & 55 & 28 \\
\hline $\mathbf{P}$ & 4,400 & 6,260 \\
\hline $\mathrm{F}^{-}$ & 150 to 187 & 34 \\
\hline $\mathrm{Cl}^{-}$ & 2,438 & 3,474 \\
\hline $\mathrm{NO}_{2}^{-}$ & 38,250 & 36,754 \\
\hline $\mathrm{NO}_{3}^{-}$ & 88,500 & 90,024 \\
\hline $\mathrm{PO}_{4}^{3-}$ & 15,225 & 18,430 \\
\hline $\mathrm{SO}_{4}^{2-}$ & 2,650 & 2,592 \\
\hline $\mathrm{CO}_{3}^{2-}$ & --- & 22,920 \\
\hline $\mathrm{OH}^{-}$ & $\cdots$ & 23,000 \\
\hline TOC & $\cdots$ & $0.441^{(b}$ \\
\hline
\end{tabular}
(a) Average of two samples with values reported; not an actual measurement of the composite.
(b) Moiar (not $\mathrm{mg} / \mathrm{L}$ ). 
TABLE 2.2. Comparison Between PNL and WHC Radionuclide Analyses of Composite Samples of Tank 106-AN Waste

\begin{tabular}{|c|c|c|}
\hline \multirow{2}{*}{$\begin{array}{c}\text { Waste } \\
\text { Constituents } \\
\end{array}$} & \multicolumn{2}{|c|}{ Radionuclide Results $(\mu \mathrm{Ci} / \mathrm{L})$} \\
\hline & PNL & WHC \\
\hline${ }^{3} \mathrm{H}$ & 0.57 & 6.85 \\
\hline${ }^{14} \mathrm{C}$ & $<5.41$ & $0.65^{(a)}$ \\
\hline${ }^{55} \mathrm{Fe}$ & 11.90 & $\cdots$ \\
\hline${ }^{59} \mathrm{Ni}$ & 0.60 & $\cdots$ \\
\hline${ }^{63} \mathrm{Ni}$ & 90.5 &.-- \\
\hline${ }^{60} \mathrm{Co}$ & 32.7 & -.- \\
\hline${ }^{79} \mathrm{Se}$ & $\cdots$ & 0.52 \\
\hline${ }^{90} \mathrm{Sr}$ & 4,160 & 4,360 \\
\hline${ }^{99} \mathrm{Tc}$ & 6.94 & $96.25^{(b)}$ \\
\hline${ }^{129} \mathrm{I}$ & 0.03 & $<0.2$ \\
\hline${ }^{137}$ Cs & $2.47 \times 10^{5}$ & $2.58 \times 10^{5}$ \\
\hline${ }^{238} \mathrm{Pu}$ & 0.017 & 0.21 \\
\hline $239,240 \mathrm{Pu}$ & 0.054 & 0.44 \\
\hline${ }^{241} \mathrm{Am}$ & 0.5 & 1.45 \\
\hline${ }^{244} \mathrm{Cm}$ & 0.0143 & -- \\
\hline${ }^{237} \mathrm{~Np}$ & -.. & 0.16 \\
\hline Gross Beta & $3.32 \times 10^{5}$ & $5.19 \times 10^{5}$ \\
\hline Gross Alpha & 0.984 & -- \\
\hline
\end{tabular}

(a) Calculated average, not actual measurement; range of individual samples used to create the composite shown.

(b) Analyses by Westinghouse Hanford Company. Range of WHC values on individual samples used to create the composite shown.

\subsection{GROUT PRODUCTION}

Grout containing waste from Tank 106 -AN was prepared by mixing $1080 \mathrm{~g}$ of dry blend with $1 \mathrm{~L}$ of liquid waste $(9 \mathrm{lb} / \mathrm{gal})$. The dry blend is a mixture of 47.5 wt\% ground blast furnace slag; 47.5 wt\% class F fly ash from Centralia, Washington; and 5 wt\% type I/II Portland cement. 
A smal1-volume mixing apparatus was built using a plastic $250-\mathrm{mL}$ separatory funnel as the mixing chamber. A schematic of the apparatus is shown in Figure 2.1. In this design, a stainless steel ball valve replaces the original stopcock at the bottom of the funnel, which allows more effective discharge of the grout. A paddle was constructed of a 1/4-in. stainless steel shaft and a metal stir bar. The shaft is attached to the stir bar with a hinge pin. The pin allows the bar to fold to the shaft for insertion into the funnel. The bottom portion of the shaft fits into the opening of the ball valve to minimize "dead space" and to prevent wobbling during mixing. The paddle was rotated with a variable speed motor. During mixing, the stir bar
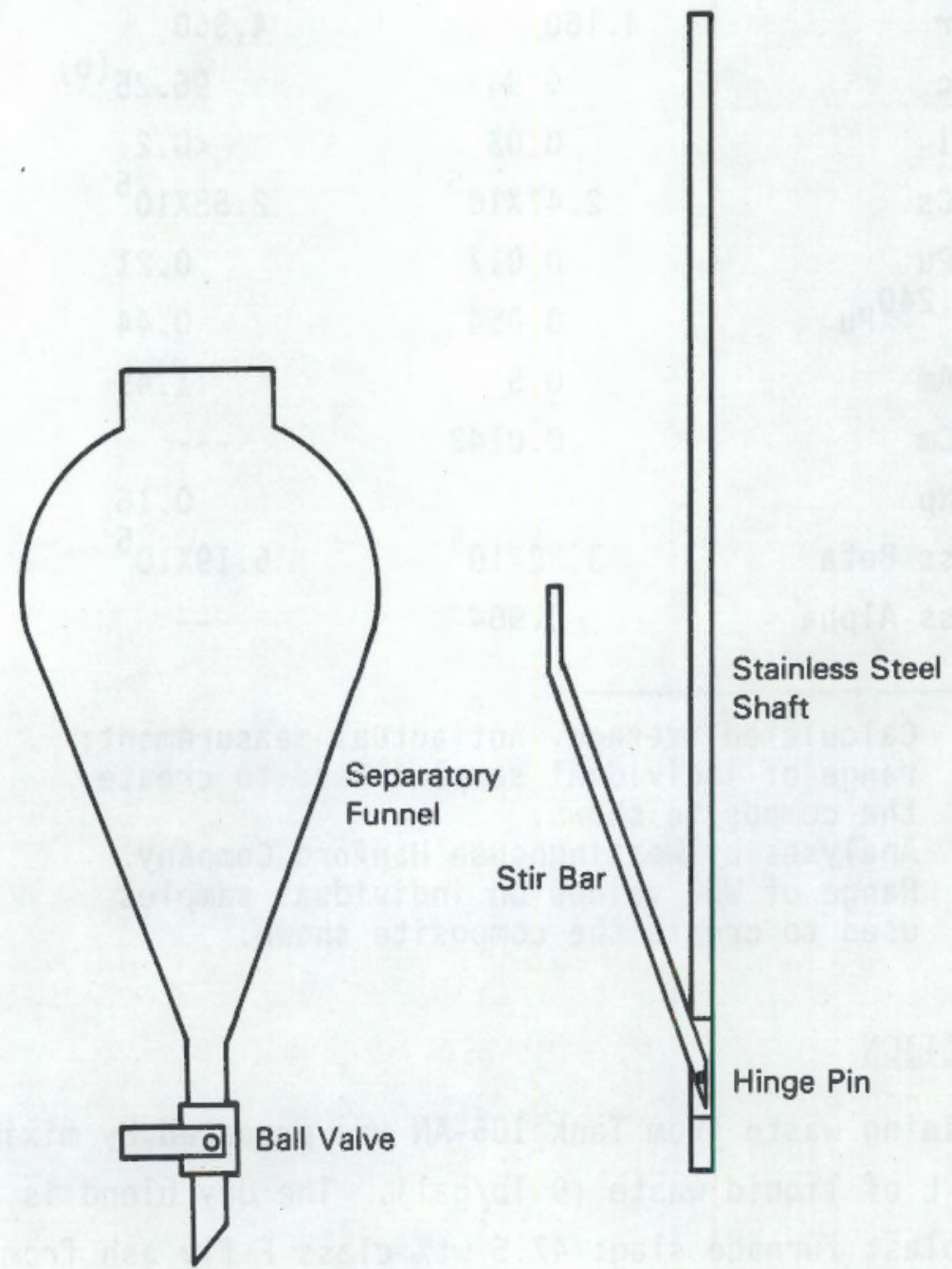

FIGURE 2.1. System Used to Mix Small Batches of Radioactive Grout 
swings out to the walls of the funnel. The mixing shaft extends above the separatory funnel and through a powder funnel used to add grout solids.

This mixing apparatus was previously developed for use in producing grouts made from phosphate/sulfate waste (PSW). This system was chosen to reduce the potential for shearing of the PSW grout during mixing. To test the application of this mixing apparatus in producing grout from Tank 106-AN waste, grouts were prepared in the usual manner in a Hobart mixer. A second batch was prepared in the separatory funnel mixer. Rheological properties of the Hobart-mixed grouts were tested using both Fann and Haake viscometers. The funnel-mixed grouts were tested in the Haake viscometer. Based on the test results, mixing for 2.5 minute at $400 \mathrm{rpm}$ in the separatory funnel mixer produced grouts with rheological properties that were comparable to those of grouts produced by conventional methods in the Hobart mixer.

Several hours prior to making the grout, the composite sample of 106-AN liquid waste was heated above $50^{\circ} \mathrm{C}$ and thoroughly mixed. A $50-\mathrm{mL}$ sample was cooled to $50^{\circ} \mathrm{C}$ during transfer to the separatory funnel mixer. A pre-measured packet of dry solids blend was added over a 15-second period and mixed for 2.5 minutes at $400 \mathrm{rpm}$. The resulting sample of slurry was used for rheological measurements. The process was repeated twice more, the first time using $150 \mathrm{~mL}$ of liquid waste and the second time using $140 \mathrm{~mL}$.

Rheological measurements of the slurry were conducted using a Haake RV-100 viscometer. The slurry was tested to a shear rate of $468 \mathrm{sec}^{-1}$ over a 5-minute period. The critical flow rate (through a 2 -in.-dia. pipe at a Reynolds number of 2100) was $17 \mathrm{gpm}$. The 10 -minute gel strength was measured at $0.7 \mathrm{~Pa}$. Figure 2.2 shows the rheogram in both the increasing and decreasing shear rate direction.

Grouts were placed in polyethylene vials with tight-fitting lids and cured in an oven at $42 \pm 2^{\circ} \mathrm{C}$. Seven $30-\mathrm{mL}$ grout specimens and one $55-\mathrm{mL}$ specimen were prepared on 0ctober 28, 1987. After 40 days of curing, the grouts had $-7 \%$ by volume drainable liquid. The volume of liquid was too small to perform complete radiological or chemical analysis and was not further characterized. On December 7, 1987, four of the 30-mL samples were removed from 


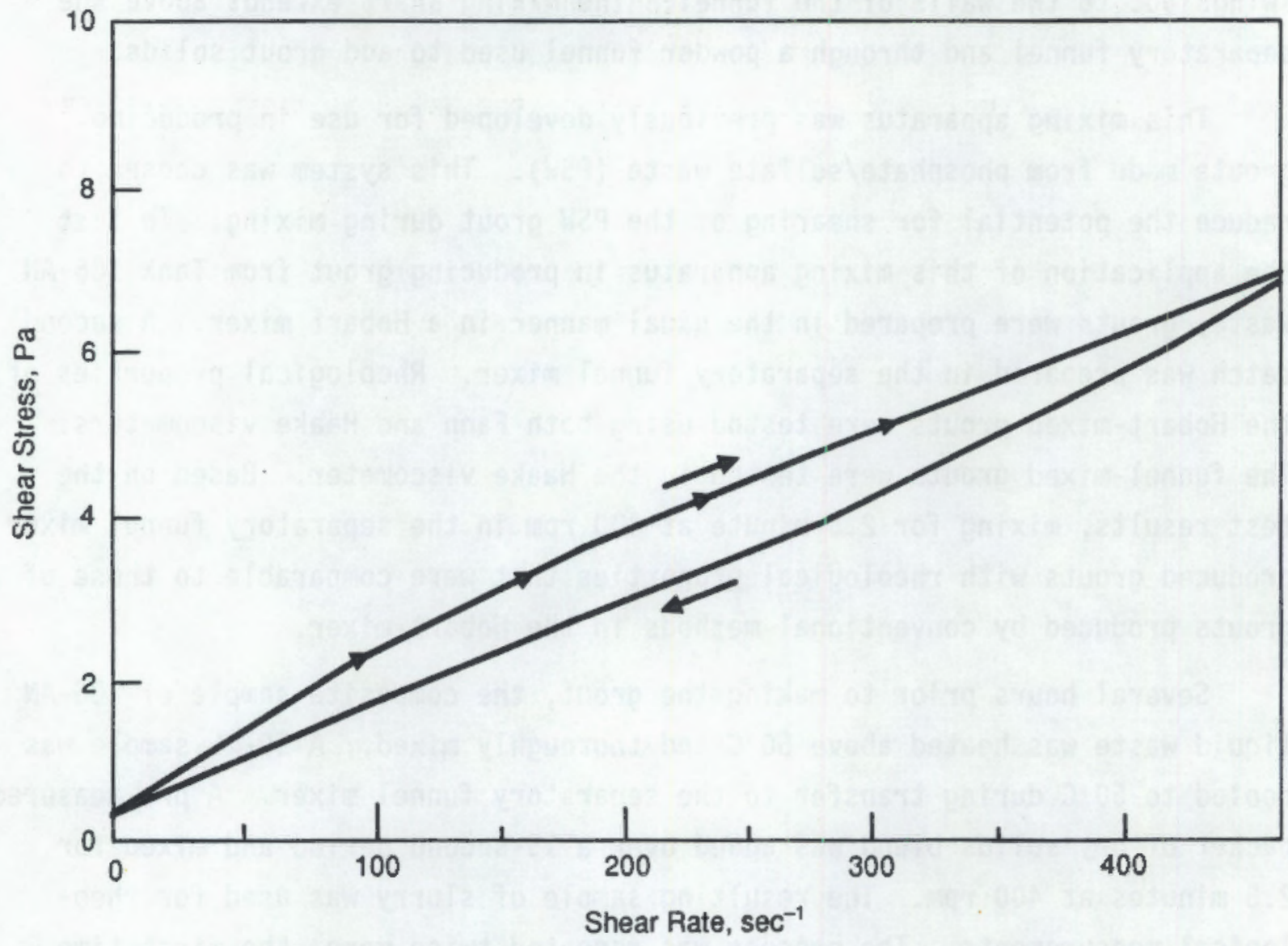

FIGURE 2.2. Rheogram for Tank 106-AN Grout

the oven and the ANS 16.1 and static leach tests were started in duplicate. The four leach tests were conducted on intact right cylinders (see Table 3.2 for the cylinder dimensions).

On December 7, 1987, the 55-mL grout sample was removed from the oven and further cured at room temperature unti1 February 17, 1988, when the EP toxicity test was performed. On February 17, the sample had no drainable liquid.

\subsection{HANFORD GROUND WATER}

Using data from the Hanford Ground-Water Monitoring Program, a well (\#6-\$3-25) has been identified on the Hanford Site that is free of contamination and provides water representative of natural waters in the unconfined aquifer underlying Hanford. Periodically, large volumes of water are pumped 
from the well into prerinsed plastic containers. The well water is then filtered through a $0.22-\mu \mathrm{m}$ membrane and stored for use in various laboratory experiments. A complete chemical analysis of the water is made on each new batch.

No significant changes in the water composition from batch-to-batch and during storage in the laboratory have been observed. The chemical composition of the batch used for the leach tests reported here is shown in Table 2.3. 
TABLE 2.3. Chemical Composition of Water from a Hanford Well(a)

\begin{tabular}{|c|c|c|}
\hline Analys is & $\underline{\text { Units }}$ & Result \\
\hline $\mathrm{pH}$ & $-\cdot-$ & 8.47 \\
\hline Eh & $m V$ & 385 \\
\hline Al & $\mathrm{mg} / \mathrm{L}$ & 0.064 \\
\hline B & $\mathrm{mg} / \mathrm{L}$ & 0.089 \\
\hline as $\mathrm{H}_{3} \mathrm{BO}_{3}$ & $\mathrm{mg} / \mathrm{L}$ & 0.52 \\
\hline $\mathrm{Ba}$ & $\mathrm{mg} / \mathrm{L}$ & 0.043 \\
\hline $\mathrm{Ca}$ & $\mathrm{mg} / \mathrm{L}$ & 58.8 \\
\hline $\mathrm{Cd}$ & $\mathrm{mg} / \mathrm{L}$ & $<0.004$ \\
\hline $\mathrm{Cr}$ & $\mathrm{mg} / \mathrm{L}$ & $<0.02$ \\
\hline $\mathrm{Cu}$ & $\mathrm{mg} / \mathrm{L}$ & $<0.004$ \\
\hline $\mathrm{Fe}$ & $\mathrm{mg} / \mathrm{L}$ & 0.019 \\
\hline K & $\mathrm{mg} / \mathrm{L}$ & 7.4 \\
\hline Mg & $\mathrm{mg} / \mathrm{L}$ & 14.0 \\
\hline Mn & $\mathrm{mg} / \mathrm{L}$ & 0.16 \\
\hline $\mathrm{Na}$ & $\mathrm{mg} / \mathrm{L}$ & 24.8 \\
\hline$P$ & $\mathrm{mg} / \mathrm{L}$ & 0.17 \\
\hline as $\mathrm{PO}_{4}$ & $\mathrm{mg} / \mathrm{L}$ & 0.51 \\
\hline $\mathrm{Pb}$ & $\mathrm{mg} / \mathrm{L}$ & $<0.06$ \\
\hline Si & $\mathrm{mg} / \mathrm{L}$ & 15.5 \\
\hline $\mathrm{Sr}$ & $\mathrm{mg} / \mathrm{L}$ & 0.238 \\
\hline $\mathrm{Zn}$ & $\mathrm{mg} / \mathrm{L}$ & $<0.02$ \\
\hline$F^{-}$ & $\mathrm{mg} / \mathrm{L}$ & 0.57 \\
\hline $\mathrm{Cl}^{-}$ & $\mathrm{mg} / \mathrm{L}$ & 22.5 \\
\hline $\mathrm{NO}_{2}^{-}$ & $\mathrm{mg} / \mathrm{L}$ & $<0.3$ \\
\hline $\mathrm{NO}_{3}^{-}$ & $\mathrm{mg} / \mathrm{L}$ & $<0.5$ \\
\hline $\mathrm{SO}_{4}^{2-}$ & $\mathrm{mg} / \mathrm{L}$ & 70.5 \\
\hline $\mathrm{PO}_{4}^{3-}$ & $\mathrm{mg} / \mathrm{L}$ & $<1.0$ \\
\hline $\mathrm{HCO}_{3}^{-}$ & $\mathrm{mg} / \mathrm{L}$ & 174 \\
\hline $\mathrm{CO}_{3}^{2-}$ & $\mathrm{mg} / \mathrm{L}$ & 0.0 \\
\hline $\begin{array}{l}\text { Total Alk } \\
\text { (as } \cos _{3}^{2} \text { ) }\end{array}$ & $\mathrm{mg} / \mathrm{L}$ & 85.68 \\
\hline $\mathrm{OH}^{-}$ & $\mathrm{mg} / \mathrm{L}$ & 0.0 \\
\hline TOC & $\mathrm{mg} / \mathrm{L}$ & 0.84 \\
\hline $\begin{array}{c}\text { Inorganic } \\
\text { carbon }\end{array}$ & $\mathrm{mg} / \mathrm{L}$ & 33.0 \\
\hline Cations & meq/L & 5.36 \\
\hline Anions & meq $/ \mathrm{L}$ & 5.00 \\
\hline
\end{tabular}

(a) This batch sampled on November 11, 1987. 


\subsection{METHODS}

This section describes the procedures used to leach the 106-AN grout. Two types of leach tests were used: an intermittent replacement leach test (ANS 16.1 leach test) and a static leach test. An EP toxicity test was also conducted on the 106-AN grout. Table 3.1 shows the sampling schedule for the ANS 16.1 leach test and the static leach test.

A11 the leach tests involving 106-AN grout used intact right cylinders. Table 3.2 identifies the tests that were conducted and describes the size of the cylinders that were used. The leach tests were conducted at room temperature. The leachant was Hanford ground water taken from well 6-\$3-25. Prior to use, the ground water was filtered through a $0.22-\mu \mathrm{m}$ membrane. Ground water was used as the leachant rather than distilled water, which is commonly used, because the leach data will be used primarily for performance assessment calculations. These calculations will simulate the release of contaminants from grout buried in unsaturated sediments, and any water reaching the grout will have a chemical nature more like ground water than distilled water. Thus, we believe our data are more representative of actual leach rates.

TABLE 3.1. Sampling Schedule for ANS 16.1 Leach Test and Static Leach Test

\begin{tabular}{cccc} 
Sample \# & $\begin{array}{c}\text { ANS } 16.1 \text { Leach Test } \\
\text { (cumulative time) }\end{array}$ & Sample \# & $\begin{array}{c}\text { Static Leach Test } \\
\text { (cumulative time) }\end{array}$ \\
\cline { 2 - 2 } 1 & 2 hours & 1 & 4 days \\
2 & 7 hours & 2 & 19 days \\
3 & 1 day & 2 & 46 days \\
4 & 2 days & 4 & 92 days \\
5 & 3 days & & \\
6 & 4 days & & \\
7 & 19 days & & \\
8 & 46 days & & \\
9 & 92 days & &
\end{tabular}


TABLE 3.2. Tests Conducted on 106-AN Grout Specimens and Dimensions of Right Cylinders

\begin{tabular}{|c|c|c|c|c|c|c|}
\hline Tests & Specimen & $\begin{array}{l}\text { Diameter } \\
(\mathrm{cm}) \\
\end{array}$ & $\begin{array}{l}\text { Length } \\
(\mathrm{cm}) \\
\end{array}$ & $\begin{array}{l}\text { Surface Area } \\
\left(\mathrm{cm}^{2}\right) \\
\end{array}$ & $\begin{array}{l}\text { Volume } \\
\left(\mathrm{cm}^{3}\right) \\
\end{array}$ & $\begin{array}{c}\text { Wet Weight } \\
\text { (g) }\end{array}$ \\
\hline Static & $S-1$ & 3.2 & 3.7 & 53.3 & 29.8 & 54.29 \\
\hline Static & $s-2$ & 3.2 & 3.9 & 55.3 & 31.4 & 56.95 \\
\hline ANS 16.1 & ANS-3 & 3.1 & 3.3 & 47.2 & 24.9 & 47.97 \\
\hline ANS 16.1 & ANS- 4 & 3.1 & 3.95 & 53.6 & 29.8 & 58.61 \\
\hline EP Tox. & EP-1 & 3.1 & 7.3 & 86.2 & 55.1 & 107.41 \\
\hline
\end{tabular}

\subsection{ANS 16.1 LEACH TESTS}

The ANS 16.1 intermittent replacement leach test consists of a procedure whereby the leachate is sampled and replaced at specific intervals (ANSI/ANS 1986). To initiate the tests, a volume of ground water (in $\mathrm{cm}^{3}$ ) equal to about 10 times the specimen's geometric surface area (in $\mathrm{cm}^{2}$ ) was added to wide-mouth polyethylene jars. Using unwaxed dental floss, the grout specimens were anchored securely to the lids of each jar and then suspended in the leachant. The ANS 16.1 leach tests were performed in duplicate.

At each sampling interval the leachate was removed, filtered through a 0.22- $\mu \mathrm{m}$ Millex-GS Millipore filter, and analyzed. The pH, Eh, and alkalinity were measured as quickly as possible. The $\mathrm{pH}$ was measured using a corning Model $130^{\circ} \mathrm{pH}$ meter and combination electrode. The alkalinity, reported as $\mathrm{mg} / \mathrm{L}$ carbonate, was measured by standard methods using a Mettler DL40 memotitrator and a micro-combination $\mathrm{pH}$ electrode [Method \#403 from American Public Health Association (1981)]. The remaining samples were used for the following analyses:

Millex-GS Millipore Filter is a registered trademark of Millipore Corporation, Bedford, Massachusetts.

- Corning Model $130 \mathrm{pH}$ meter is a registered trademark of Corning Glass Works, Medfield, Massachusetts.

(8) Mettler DL40 memotitrator is a registered trademark of Mettler Instrument Corporation, Highstown, New Jersey. 
1. Approximately $20 \mathrm{~mL}$ were provided for IC anion analyses.

2. Approximately $20 \mathrm{~mL}$ were provided for ICP emission spectrometry. The samples were acidified with U1trex ${ }^{8} \mathrm{HCl}$ to a $\mathrm{pH}$ of $<2$.

3. The remaining volume $(-300 \mathrm{~mL})$ was given to a radiochemist, who performed the wet chemical separations and individual radionuclide counting.

Unlike previous leaching tests performed by PNL, total carbon (TC) and total organic carbon (TOC) analyses were not performed because the leachates contained significant amounts of radioactivity, above allowable limits for analyses on our carbon analyzers. In addition, the radionuclide and chemical plateout on containers at each sampling interval was not monitored.

The cations in solution were measured using an ICP spectrophotometer (Applied Research Laboratories Model \#35800). The instrument can simultaneously measure over 30 elements, although we report data for only the following: $\mathrm{Al}, \mathrm{B}, \mathrm{Ba}, \mathrm{Ca}, \mathrm{Cd}, \mathrm{Cr}, \mathrm{Cu}, \mathrm{Fe}, \mathrm{K}, \mathrm{Li}, \mathrm{Mg}, \mathrm{Mn}$, Mo, $\mathrm{Na}, \mathrm{Ni}, \mathrm{Pb}, \mathrm{Si}$, $\mathrm{Sr}$, and $\mathrm{Zn}$. Most other elements are not present in the grout leachates at measurable concentrations.

The anions in solution were measured using a Dionex mode1 $\# 2310^{\circledR}$ ion chromatograph. The constituents measured were $\mathrm{F}^{-}, \mathrm{Cl}^{-}, \mathrm{NO}_{2}^{-}, \mathrm{NO}_{3}^{-}, \mathrm{SO}_{4}^{2-}$, and $\mathrm{PO}_{4}^{3-}$.

\subsection{STATIC LEACH TESTS}

Two right cylinders of grout were suspended in separate, wide-mouthed polyethylene jars filled with Hanford ground water at a volume (in $\mathrm{cm}^{3}$ ) equal to about 10 times the geometric surface area (in $\mathrm{cm}^{2}$ ) of the grout sample. At the prescribed times, $50 \mathrm{~mL}$ of leachate were removed from the container

(1) U1trex acids are a registered tradename of J. T. Baker Chemical Company, Jackson, Tennessee.

(4) Applied Research Laboratories ICP spectrophotometer (Model \#3580) is a registered trademark of Applied Research Laboratories, Miami, Florida.

- Dionex Model \#2310 ion chromatograph is a registered trademark of Dionex Corporation, Sunnyvale, California. 
and filtered through a $0.22-\mu \mathrm{m}$ membrane. The effluents were analyzed for the same constituents and treated exactly as described for the ANS 16.1 leach tests. To replenish the leachate removed for analysis, $50 \mathrm{~mL}$ of fresh Hanford ground water were added and the experiment was continued. Because only $50 \mathrm{~mL}$ of leachate was removed, radiocounting consumed the available sample. This sample was analyzed for radionuclides after measuring its $\mathrm{pH}$; therefore, chemical analyses were not obtained on this one sample. The duplicate static leach test provided the sample used for chemical analyses.

\subsection{EXTRACTION PROCEDURE TOXICITY TESTS}

The EP toxicity test was performed on an intact grout sample produced with waste from Tank 106-AN. This test is an Environmental Protection Agency test method (U.S. EPA 1982) that is intended to determine whether a waste exhibits the characteristics of EP toxicity. A $107-\mathrm{g}$ sample was placed in a 2-L container, along with distilled water equal to 16 times the sample weight. During the test the sample container was tumbled at $30 \mathrm{rpm}$, and the $\mathrm{pH}$ was measured periodically and adjusted to $5 \pm 0.2$ using a $0.5 \mathrm{~N}$ acetic acid solution. The $\mathrm{pH}$ adjustment continued for 6 hours. After 24 hours, the $\mathrm{pH}$ was measured and additional acid was added to reduce the $\mathrm{pH}$ to 5 . Agitation continued for an additional 4 hours. During the EP toxicity test, the grout sample chipped and several small pieces were present along with the large sample. At the end of the test, distilled water was added to bring the total solution weight equal to 20 times the sample weight. An aliquot of the solution was then filtered through a $0.45-\mu \mathrm{m}$ filter and submitted for ICP analys is of specific metals. The level of mercury in the leachate was determined using a flameless atomic absorption method.

The Structural Integrity Test (SIT) was performed on a simulated Tank 106-AN waste solidified in grout. This grout sample remained intact following the integrity test; therefore, it was assumed that the grouts produced using actual liquid waste would also remain intact. 


\subsection{RESULTS AND DISCUSSION}

The results of the ANS 16.1 leach tests, static leach tests, and EP toxicity leach tests are presented in this section, along with an interpretation of the results. Measured chemical data from the ANS 16.1 and static leach tests are provided in Appendix A. Appendix B lists the radionuclide counting data (corrected for decay to the start of the leach tests) and effective diffusion coefficient $\left(D_{e}\right)$ calculations for all constituents that leached. Appendix $C$ contains mass balance calculations for selected chemicals. Appendix $D$ contains the raw counting data for radionuclides, and Appendix $E$ contains initial inventory $\left(A_{0}\right)$ calculations for selected species.

\subsection{LEACHATE CHEMISTRY FOR ANS 16.1 AND STATIC LEACH TESTS}

For both tests, Figure 4.1 and Tables A.1 through A.4 show an immediate rise in solution $\mathrm{pH}$ from the ambient ground-water value of 8.47 upon contact

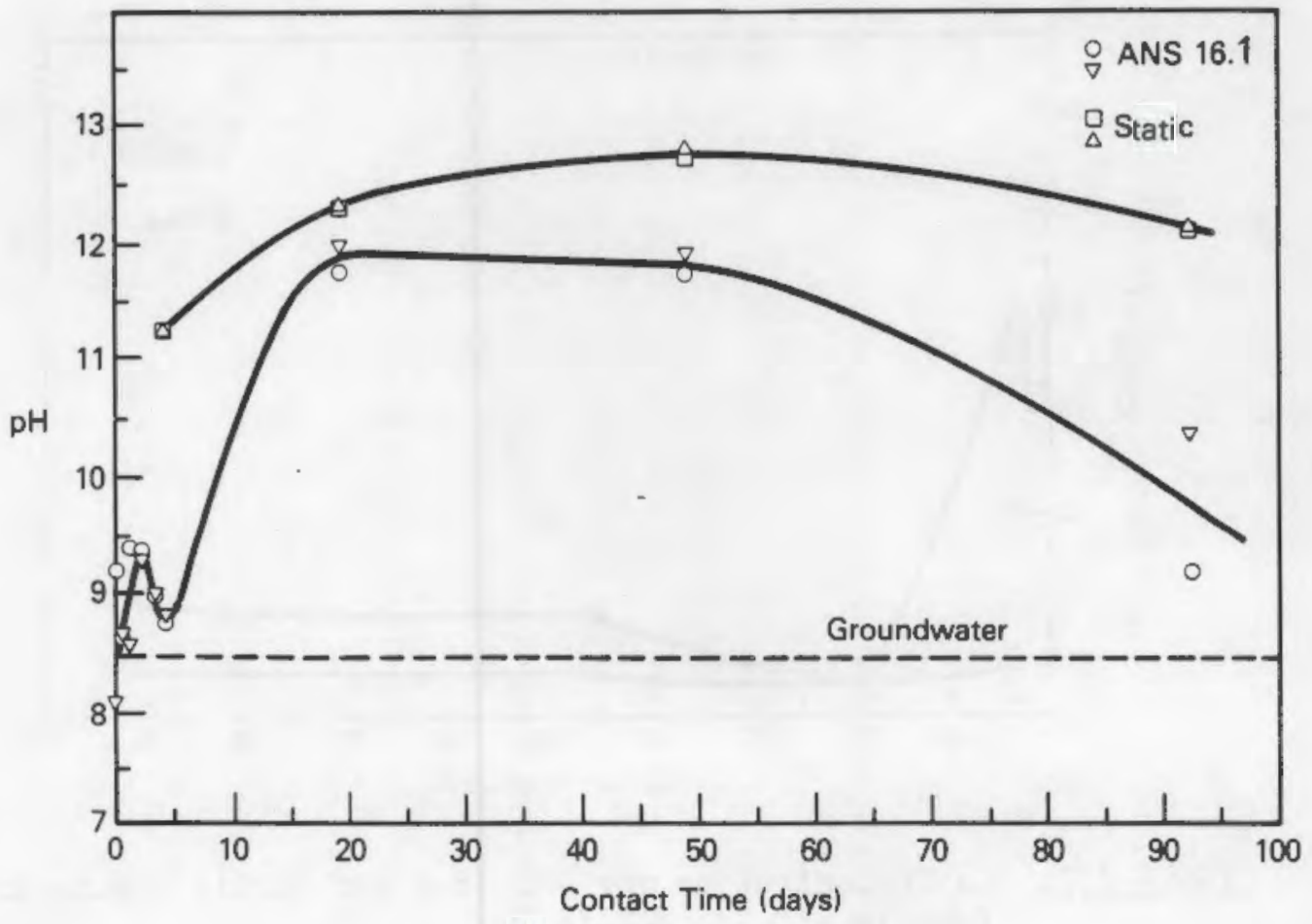

FIGURE 4.1. PH Values for ANS 16.1 and Static Leachates from Intact Grout Cylinders 
with the grout. For the ANS 16.1 test leachates, the $\mathrm{pH}$ values for the 2-hour through 2-day samples were between 8.1 and 9.4. At 19 days and 46 days, the leachate $\mathrm{pH}$ peaked at values of 11.8 to 12.0 , then dropped to about 9.5 at 92 days. In contrast, the $\mathrm{pH}$ values from the static leach tests rose to 11.25 after 4 days, then remained above 12 for the remainder of the test. The difference in $\mathrm{pH}$ values was caused by the intermittent changes of leachant during the ANS 16.1 test, which replenished the bicarbonate $\left(\mathrm{HCO}_{3}^{-}\right)$content of the leach water. Continually replenishing the $\mathrm{HCO}_{3}^{-}$with fresh ground water during the ANS 16.1 test removed hydroxide and calcium ions from the solution through precipitation of calcium carbonate. In the static leach tests, after the $\mathrm{HCO}_{3}^{-}$content was depleted, the $\mathrm{pH}$ continued to rise because no additional bicarbonate was added to neutralize the excess $\mathrm{OH}^{-}$that was released.

Figure 4.2 shows the Ca concentrations measured in the leachates. In each test there was a net decrease in Ca concentrations compared to the

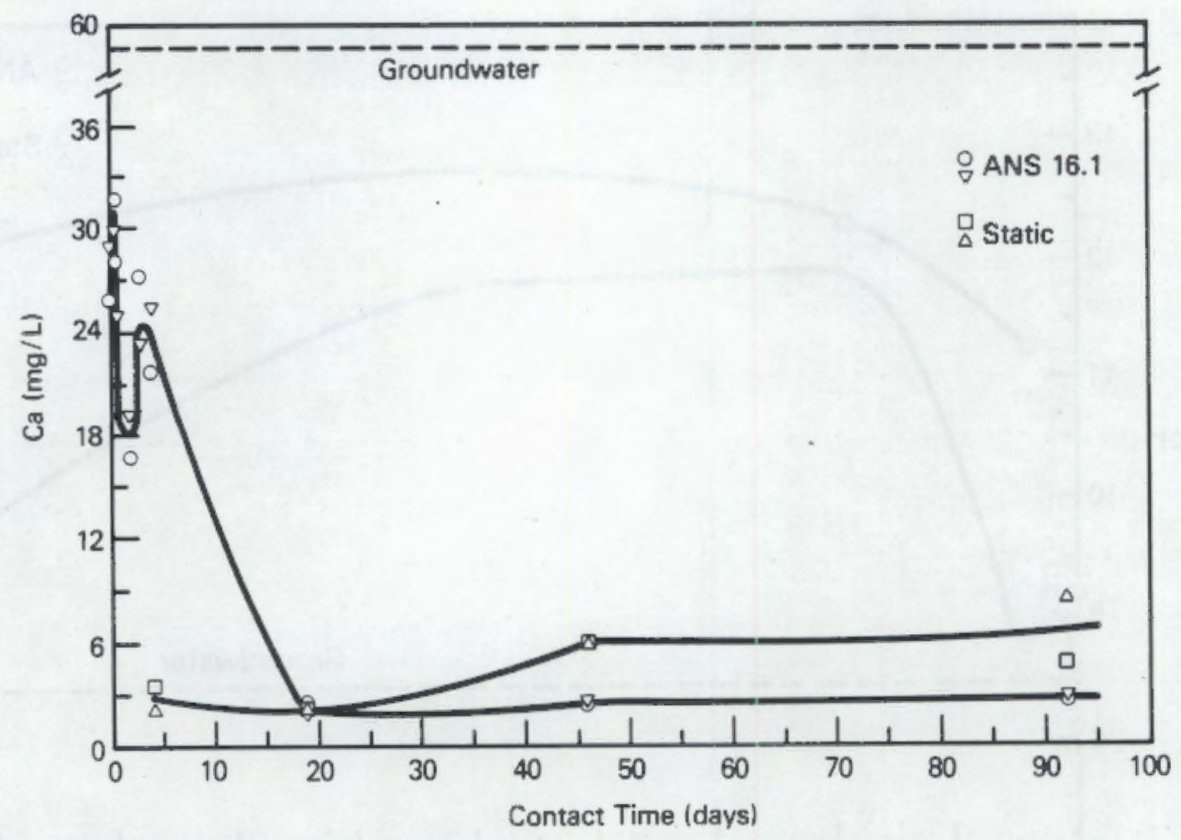

FIGURE 4.2. Ca Concentration for ANS 16.1 and Static Leachates from Intact Grout Cylinders 
ground-water concentrations. The replicate samples of the ANS 16.1 and static leach tests showed good reproducibility. The decrease in $\mathrm{Ca}$ and carbonate concentrations (see Appendix A) suggests that $\mathrm{CaCO}_{3}$ precipitated. Although the ANS 16.1 leachates exhibited higher concentrations of $\mathrm{Ca}$ than the leachates from the static leach tests, the actual mass precipitated was larger. This difference occurred because the entire inventory of ANS 16.1 leachate solution was changed at each sampling time (470 to $540 \mathrm{~mL}$ ), whereas in the static leach test, only $50 \mathrm{~mL}$ of solution was changed in the leach vessels at each sampling time. After 92 days, the ANS 16.1 leach test samples showed a net precipitation of at least $221 \mathrm{mg}$ of calcium, whereas the static leach tests showed a net precipitation of only $39.6 \mathrm{mg}$ of calcium. These calculated precipitation values account only for losses from the original leachant and do not account for the Ca mass that leaches from the grout and reprecipitates.

The chemical compositions of the leachates from the 92-day static leach test and the 2-hour, 7-hour, 19-day, and 92-day ANS 16.1 leach tests were input to the geochemical code MINTEQ (Felmy, Girvin and Jenne 1984 and Peterson et a1. 1987). The solutions were speciated and ion activity products calculated for common minerals. The ion activity products were compared to mineral solubility products to evaluate whether specific minerals were in equilibrium, oversaturated, or undersaturated with respect to the leachate.

The computer analyses suggested that the leachates from the ANS 16.1 and static leach test at 19 through 92 days were in equilibrium with carbonate minerals such as calcite, aragonite, and/or magnesite. The early ANS 16.1 test leachates ( 2 and 7 hour) were oversaturated, suggesting that the carbonates were still forming and had not completely precipitated to a condition of equilibrium. Appendix $C$ contains estimates of the masses of constituents either leached or precipitated in all of the leach tests.

There were also distinct differences in the $\mathrm{Mg}, \mathrm{Na}$, and $\mathrm{K}$ leachate concentrations between the two tests. Figures $4.3,4.4$, and 4.5 show the leachate concentrations for $\mathrm{Mg}, \mathrm{Na}$, and $\mathrm{K}$, respectively. In the ANS 16.1 tests, the $\mathrm{Mg}$ concentrations dipped slightly from 14 to 8 to $11.7 \mathrm{mg} / \mathrm{L}$ between 2 hours and 4 days. At the longer times (19 and 92 days), the $\mathrm{Mg}$ 


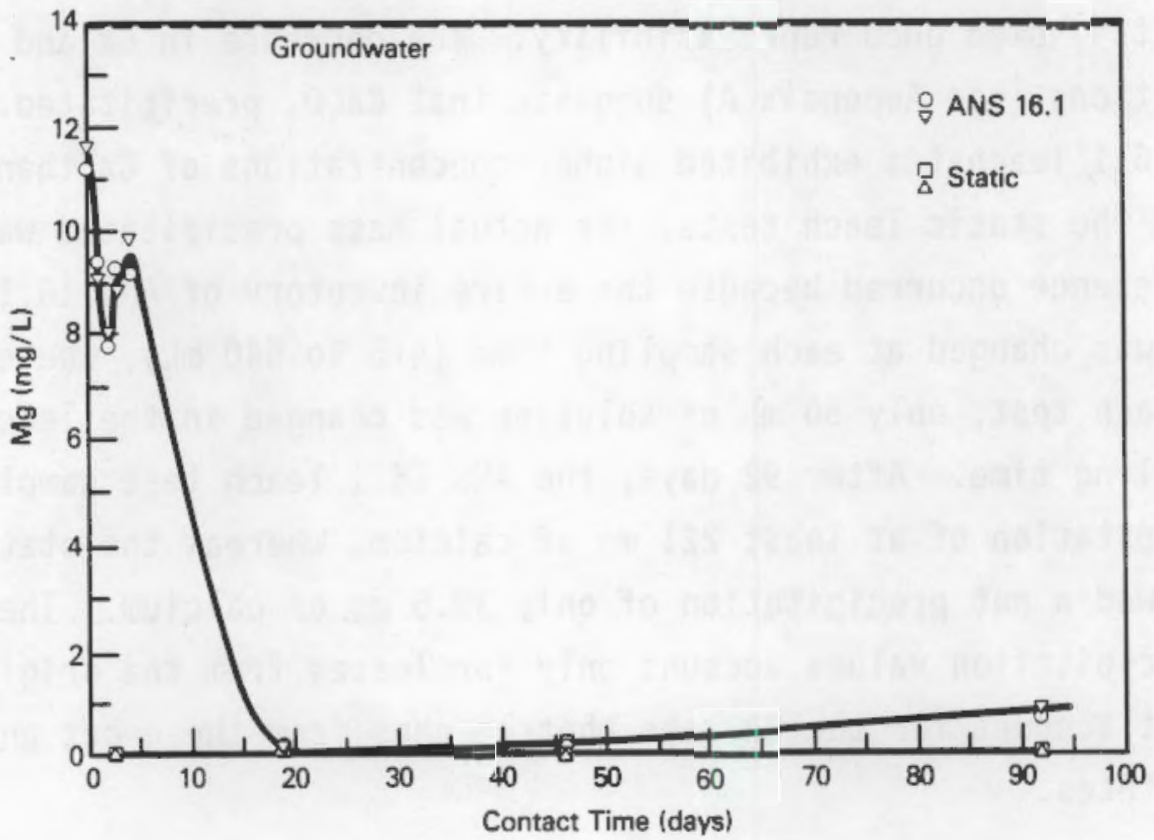

FIGURE 4.3. Mg Concentration for ANS 16.1 and Static Leachates from Intact Grout Cylinders

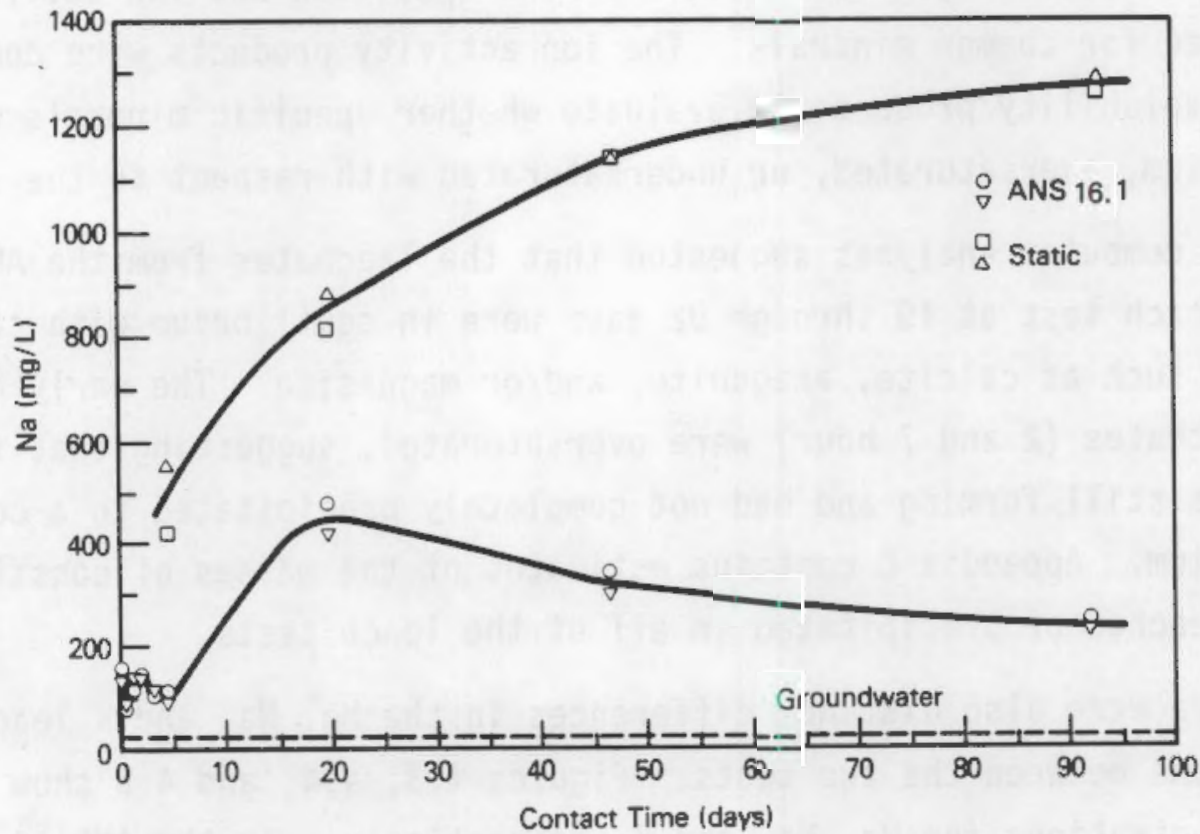

FIGURE 4.4. Na Concentration for ANS 16.1 and Static Leachates from Intact Grout Cylinders 


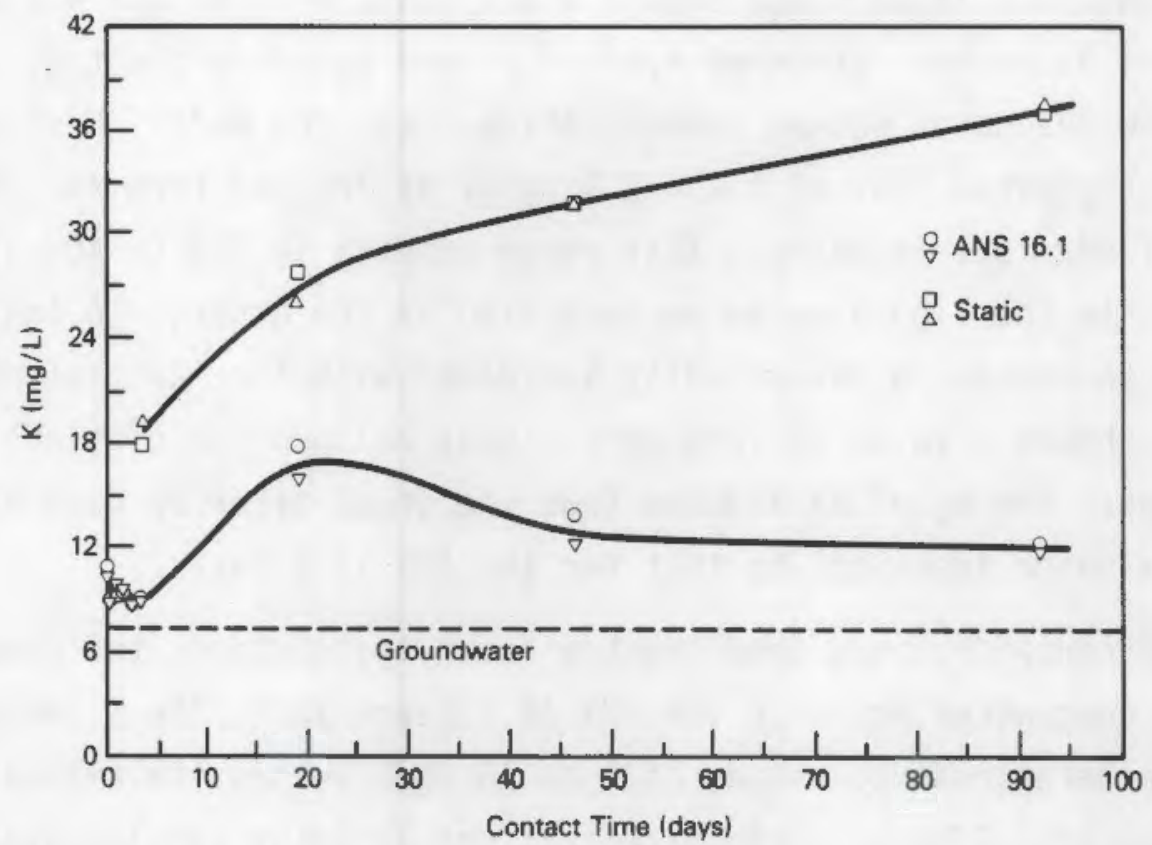

FIGURE 4.5. K Concentration for ANS 16.1 and Static Leachates from Intact Grout Cylinders

concentrations dropped to values below $1 \mathrm{mg} / \mathrm{L}$. In contrast, the $\mathrm{Mg}$ concentration of the leachate from the static leach test rapidly decreased after 4 days of contact and remained below the detection limit. MINTEQ code predictions suggested that the rapid decrease in magnesium concentrations in the static leach tests was caused by the precipitation of brucite $\left[\mathrm{Mg}(\mathrm{OH})_{2}\right]$. MINTEQ predicted that neither brucite nor $\mathrm{MgCO}_{3}$ controlled the observed $\mathrm{Mg}$ solution concentrations in ANS 16.1 test leachates. A mixed $\mathrm{Ca}, \mathrm{Mg}$ carbonate mineral may be the controlling solid.

At a minimum, $40 \mathrm{mg}$ of $\mathrm{Mg}$ precipitated in the ANS 16.1 leach tests and at least $10.5 \mathrm{mg}$ of $\mathrm{Mg}$ has precipitated in the static leach tests. MINTEQ predicts that portlandite dissolving in distilled water with a very $\mathrm{low}^{\mathrm{CO}} \mathrm{C}_{2}$ content would reach a steady-state $\mathrm{pH}$ value of 12.42 . Perhaps other species that are present could lower the $\mathrm{pH}$ to the observed value of 12.1. Whatever the cause, grout contacting Hanford ground water under stagnant flow conditions will generate a leachate with a $\mathrm{pH}$ value of about 12 that is in equilibrium with brucite $\left[\mathrm{Mg}(\mathrm{OH})_{2}\right]$. 
The ANS 16.1 leach tests showed a net release of $\mathrm{Na}$ and $\mathrm{K}$ from the grout. The ambient $\mathrm{Na}$ concentration of Hanford ground water is about $25 \mathrm{mg} / \mathrm{L}$, whereas most of the leachates showed concentrations over $200 \mathrm{mg} / \mathrm{L}$. Mass balance calculations suggested that at least $860 \mathrm{mg}$ of $\mathrm{Na}$ leached from the grout after 92 days of ANS 16.1 leaching. This range amounts to $35 \%$ to $40 \%$ of the total Na present in the liquid waste encapsulated in the grout. In the static leach test, the $\mathrm{Na}$ concentration steadily increased with time and, after 92 days of leaching, showed a value of $1250 \mathrm{mg} / \mathrm{L}$. Mass balance calculations suggested that at least $860 \mathrm{mg}$ of $\mathrm{Na}$ leached from the grout after 92 days of static testing, a value identical to that for the ANS 16.1 tests.

The $K$ concentrations from the two leach tests showed the same patterns as the $\mathrm{Na}$ concentrations. In the ANS 16.1 leach test, the $\mathrm{K}$ concentrations in the leachates rose to values of 9 to $16 \mathrm{mg} / \mathrm{L}$ versus the ambient groundwater value of $7.4 \mathrm{mg} / \mathrm{L}$. The concentrations in later samples stabilized in the range of 12 to $13 \mathrm{mg} / \mathrm{L}$. Mass balance calculations for the ANS 16.1 leach tests showed about 18 to $20 \mathrm{mg}$ of $\mathrm{K}$ released from the grout. In the static leach tests, $K$ concentrations slowly increased and, after 92 days, were near $37 \mathrm{mg} / \mathrm{L}$. Mass balance calculations for the static leach test showed a release of $20.5 \mathrm{mg}$ of $\mathrm{K}$, similar to the mass calculated for the ANS 16.1 leach test. The total $K$ released to date is greater than $70 \%$ of the $K$ in the liquid waste. Much of the $K$ that has leached comes from the materials in the solid blend. Previous leach studies on grouts made with liquids that contained very low concentrations of $K$ show similar masses of $K$ leached.

After $\mathrm{CaO}$, the two largest components of the grout are generally $\mathrm{Al}_{2} \mathrm{O}_{3}$ and $\mathrm{SiO}_{2}$. In the ANS 16.1 leach test, Al concentrations were consistently below $2 \mathrm{mg} / \mathrm{L}$ and Si concentrations were consistently between 12.4 to $19 \mathrm{mg} / \mathrm{L}$, which is very close to the ambient ground-water value of $15 \mathrm{mg} / \mathrm{L}$. In the static leach test, the $\mathrm{Al}$ concentration in the leachates slowly increased to $15 \mathrm{mg} / \mathrm{L}$. The $\mathrm{Si}$ concentrations showed a slight release above the ambient ground-water value of $15 \mathrm{mg} / \mathrm{L}$. The increase in Al concentrations in the leachates from the static leach test can be explained by the rise in $\mathrm{pH}$ to values near 12. Solution concentrations of Al are often larger in natural systems when $\mathrm{pH}$ values exceed 10 . 
MINTEQ predictions suggested that the Al concentrations in the static leach test leachates were slightly oversaturated with respect to diaspore $[\mathrm{AlO}(\mathrm{OH})]$ and undersaturated with respect to gibbsite $\left[\mathrm{Al}(\mathrm{OH})_{3}\right]$ and boehmite $[\gamma-A 10(\mathrm{OH})]$. A11 of the leachates from the ANS 16.1 leach test were in equilibrium with gibbsite or boehmite when $\mathrm{pH}$ values were below 10.5, and with diaspore when $\mathrm{pH}$ values were larger than 10.5. It appears that in high $\mathrm{pH}$ environments diaspore may control the solution concentrations of $\mathrm{A} 7$, while at $\mathrm{pH}$ values less than $\mathbf{1 0 . 5}$ boehmite or gibbsite may control.

The observed $\mathrm{Si}$ concentrations in the leachates with $\mathrm{pH}$ values over 10 were undersaturated with respect to $\mathrm{SiO}_{2}(\mathrm{am})$, chalcedony, or sepiolite, three minerals that have appeared to be controls in other grouts. At lower $\mathrm{pH}$ values, the leachates may be in equilibrium with chalcedony, a cryptocrystalline form of quartz.

The leachates showed moderate levels of sulfate and a trace of phosphate, but no common su?fate- or phosphate-bearing minerals appeared to be in equilibrium. All the sulfate minerals considered (gypsum, calcium monosulfate, and ettringite) were undersaturated, and all the common phosphatebearing minerals would control phosphate concentrations at values below our detection limits.

The 1 iquid waste contained large concentrations of nitrate and nitrite. Figures 4.6 and 4.7 show the effluent concentrations of nitrate and nitrite, respectively. The nitrate and nitrite levels in the ANS 16.1 leach test leachates peaked at 19 days before slowly dropping to values above $200 \mathrm{mg} / \mathrm{L}$ and $80 \mathrm{mg} / \mathrm{L}$, respectively. The total mass leached in 92 days for both tests was similar: $-810 \mathrm{mg}$ of $\mathrm{NO}_{3}^{-}$and $375 \mathrm{mg}$ of $\mathrm{NO}_{2}^{-}$. This amount represents $37 \pm 2 \%$ of the nitrate and nitrite originally present in the liquid waste. Some fluoride, chloride, and sulfate also leached from the grouts, as shown in Appendix A.

Leachates from both tests generally showed no detectable releases of the trace metals $(\mathrm{Cd}, \mathrm{Cr}, \mathrm{Cu}, \mathrm{Mn}, \mathrm{Pb}$, and $\mathrm{Zn})$. However, there appeared to be a measurable release of Mo and Ni. More quantitative discussions appear in the next section, where leach rates from grout are discussed. 


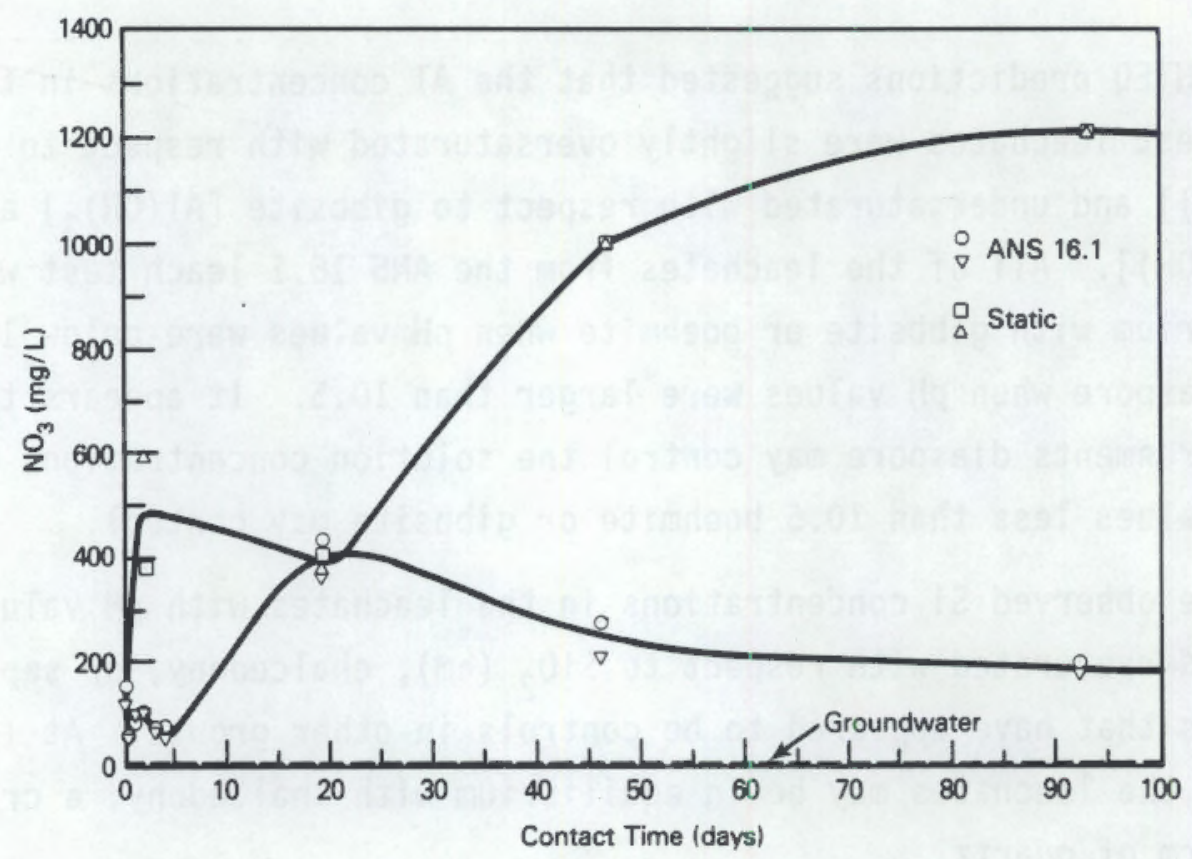

FIGURE 4.6. $\mathrm{NO}_{3}$ Concentration in ANS 16.1 and Static Leachates from Intact Grout Cylinders

\subsection{LEACH RATES OF SELECTED SPECIES}

The leach data for selected trace metals, major chemical species, and radionuclides using the semi-infinite-solid mass transport diffusion model are described here. The data on mass or radioactivity found in the leachates, after correction for radioactive decay to the start of the experiments, are shown in Appendix B. For the ANS 16.1 leach test, the cumulative fraction leached and incremental fraction leached at each sampling interval are also provided in Appendix B.

In previous work (Serne et al. 1987), we concluded that the semiinfinite solid diffusion leach model was appropriate. This type of diffusion model is the most popular release model used to describe the leaching of grouts and other cement waste forms. This model is used by researchers at Brookhaven National Laboratory (Kalb and Columbo 1984; Arora and Dayal 1984; Daya1, Schweitzer and Davis 1984; Dayal, Arora and Morcos 1983); at ORNL (Moore, Godbee and Kibbey 1977; Godbee, Anders and Nielson 1980; Clark 1977); 


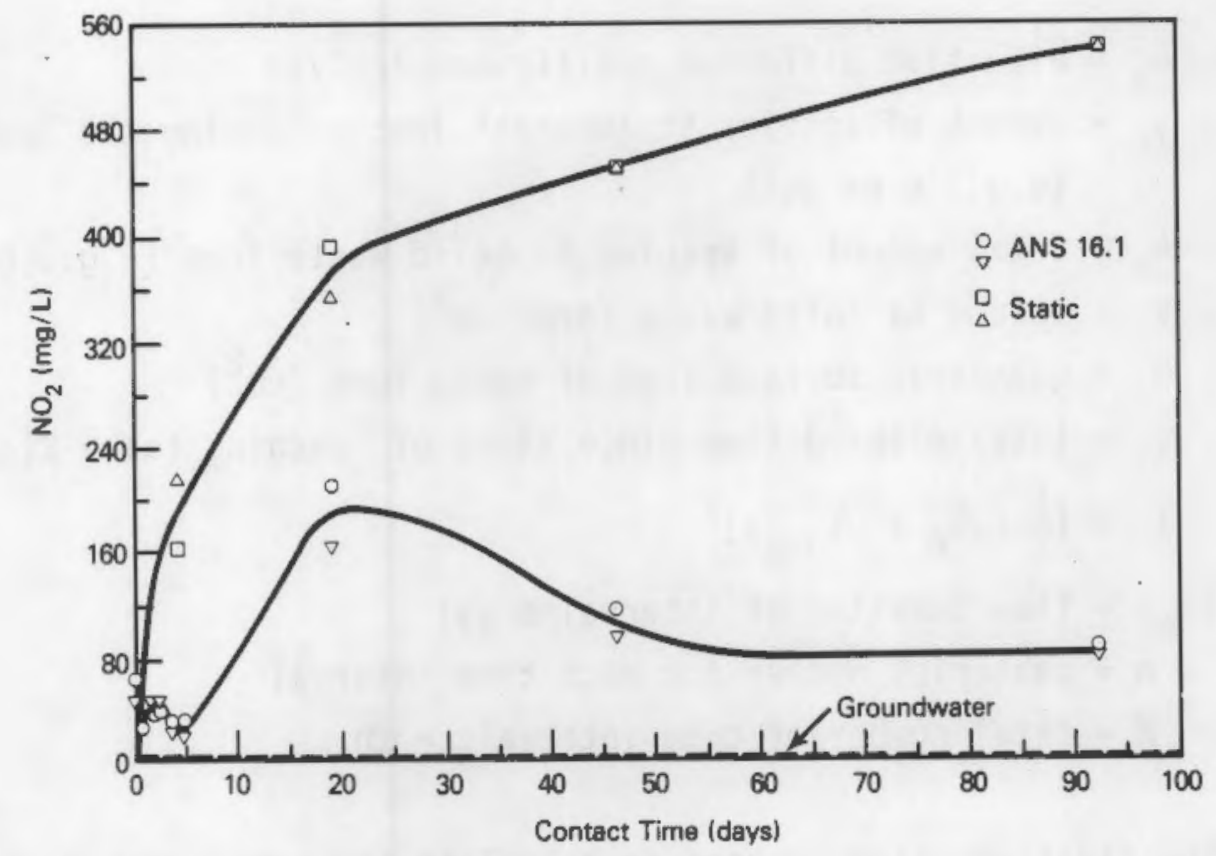

FIGURE 4.7. $\mathrm{NO}_{2}$ Concentration in ANS 16.1 and Static Leachates from Intact Grout cylinders

at the Japan Atomic Energy Research Institute (Matsuzuru and Moriyama 1982; Moriyama, Dojiri and Matsuzuru 1977); and at the United Kingdom Atomic Energy Authority, Harwell (Sambel1, Smitton and Elsden 1982). The model is used to analyze laboratory leach data on cylindrical blocks of cement or grout waste forms in which nuclear wastes are incorporated, and is endorsed by the American Nuclear Society (ANS). In addition, the model is the basis for the recommended leach test ANSI/ANS-16.1, "Measurement of the Leachability of Solidified Low-Level Radioactive Wastes by a Short-Term Test Procedure" (ANSI/ANS 1986).

Equations for the calculation of $D_{e}$ follow:

$$
\begin{gathered}
D_{e}=\frac{\pi}{4}\left(\begin{array}{l}
N \\
\sum \\
\frac{n=1}{A_{0}}
\end{array}\right)^{2}\left(\frac{v}{s}\right)^{2} \frac{1}{t} \\
D_{e}=\pi\left(\frac{a_{n}}{A_{0}}\right)^{2}\left(\frac{v}{s}\right)^{2} \frac{T}{\left(\Delta t_{n}\right)^{2}}
\end{gathered}
$$


where $D_{e}=$ effective diffusion coefficient $\left(\mathrm{cm}^{2} / \mathrm{s}\right)$

$a_{n}=$ amount of species of interest leached during the leach interval (e.g., g or $\mu \mathrm{Ci}$ )

$A_{0}=$ total amount of species in solid waste form (e.g., g or $\mu \mathrm{Ci}$ ) $V=$ volume of solid waste form $\left(\mathrm{cm}^{3}\right)$

$S=$ geometric surface area of waste form $\left(\mathrm{cm}^{2}\right)$

$t=$ total elapsed time since start of leaching $(s)=\Sigma(\Delta t)_{n}=t_{n}$

$T=\left[\frac{1}{2}\left(\sqrt{t_{n}}+\sqrt{t_{n-1}}\right)\right]^{2}$

$\left(\Delta t_{n}\right)=$ time duration of interval $n(s)$

$\mathrm{n}$ = subscript number for each time interval

$\mathrm{N}=$ total number of time intervals $=\Sigma \mathrm{n}$.

The first equation is used to calculate the cumulative diffusion coefficient for species " $i$," and the second equation is used to calculate the instantaneous or incremental diffusion coefficient for species " $i$ " at each leach interval " $n$." The effective cumulative diffusion coefficients, $D_{e}$, are listed in Table 4.1 for the constituents for both the ANS 16.1 and static leach tests in which Hanford ground water was the leachant. Appendix B also lists values of the incremental $\mathrm{D}_{\mathrm{e}}$ obtained by separately evaluating each ANS 16.1 leach test interval. These values are a useful check to see if any one data point is an outlier. The cumulative approach would propagate the effect of the outlier through all further calculations.

If leaching were accurately described by the semi-infinite-solid diffusion model, the $D_{e}$ values should be constant with time. It can be seen in Table 4.1 and Appendix $B$ that the cumulative $D_{e}$ values for the ANS 16.1 data decrease with time. Appendix $B$ also shows that the incremental $D_{e}$ values generally decrease with time, although certain samples show fluctuations.

The species with the highest leach rates $\left(>5 \times 10^{-9} \mathrm{~cm}^{2} / \mathrm{s}\right.$ cumulative effective diffusion coefficients) include ${ }^{99} \mathrm{Tc},{ }^{129} \mathrm{I}_{\mathrm{Cl}^{-}}, \mathrm{NO}_{2}^{-}, \mathrm{NO}_{3}^{-}$and $\mathrm{Na}$. Under static test conditions, Mo showed effective diffusion coefficients above $5 \times 10^{-9} \mathrm{~cm}^{2} / \mathrm{s}$. Nickel and ${ }^{137} \mathrm{Cs}$ showed effective diffusion coefficients in 
TABLE 4.1. Cumulative $D_{e}$ Values for Species Leaching From Tank 106-AN Grout $\left(\mathrm{cm}^{2} / \mathrm{s}\right)$

\begin{tabular}{|c|c|c|c|}
\hline Constituent & (days) & ANS 16.1 Leach Test & Static Leach Test \\
\hline \multirow[t]{4}{*}{$\mathrm{NO}_{3}^{-}$} & 4 & $1.2 \pm 0.1 \times 10^{-8}$ & $1.1 \pm 0.4 \times 10^{-8}$ \\
\hline & 19 & $1.0 \pm 0.1 \times 10^{-8}$ & $2.1 \pm 0.2 \times 10^{-9}$ \\
\hline & 46 & $7.0 \pm 0.4 \times 10^{-9}$ & $7.0 \pm 0.4 \times 10^{-9}$ \\
\hline & 92 & $4.6 \pm 0.7 \times 10^{-9}$ & $6.2 \pm 0.5 \times 10^{-9}$ \\
\hline \multirow[t]{4}{*}{$\mathrm{NO}_{2}^{-}$} & 4 & $1.6 \pm 0.5 \times 10^{-8}$ & $1.1 \pm 0.4 \times 10^{-8}$ \\
\hline & 19 & $1.2 \pm 0.2 \times 10^{-8}$ & $1.1 \pm 0.3 \times 10^{-8}$ \\
\hline & 46 & $8.1 \pm 0.4 \times 10^{-9}$ & $8.1 \pm 0.4 \times 10^{-9}$ \\
\hline & 92 & $5.8 \pm 1.0 \times 10^{-9}$ & $6.9 \pm 0.6 \times 10^{-9}$ \\
\hline \multirow[t]{4}{*}{$\mathrm{Cl}^{-}$} & 4 & $3.5 \pm 1.1 \times 10^{-8}$ & $3.0 \pm 0.7 \times 10^{-9}$ \\
\hline & 19 & $2.3 \pm 0.3 \times 10^{-8}$ & $8.3 \pm 1.1 \times 10^{-9}$ \\
\hline & 46 & $1.4 \pm 0.1 \times 10^{-8}$ & $6.5 \pm 0.3 \times 10^{-9}$ \\
\hline & 92 & $8.9 \pm 1.0 \times 10^{-9}$ & $6.9 \pm 0.6 \times 10^{-9}$ \\
\hline \multirow[t]{4}{*}{$\mathrm{F}^{-}$} & 4 & $6.7 \pm 5.2 \times 10^{-10}$ & $1.1 \pm 0.5 \times 10^{-9}$ \\
\hline & 19 & $1.4 \pm 0.2 \times 10^{-9}$ & $1.3 \pm 0.6 \times 10^{-9}$ \\
\hline & 46 & $1.1 \pm 0.1 \times 10^{-9}$ & $7.2 \pm 0.4 \times 10^{-10}$ \\
\hline & 92 & $4.1 \pm 0.5 \times 10^{-10}$ & $4.9 \pm 0.4 \times 10^{-10}$ \\
\hline \multirow[t]{4}{*}{$\mathrm{Na}$} & 4 & $1.4 \pm 0.5 \times 10^{-8}$ & $1.1 \pm 0.3 \times 10^{-8}$ \\
\hline & 19 & $1.1 \pm 0.3 \times 10^{-9}$ & $9.0 \pm 2.1 \times 10^{-9}$ \\
\hline & 46 & $7.6 \pm 1.1 \times 10^{-9}$ & $7.8 \pm 0.1 \times 10^{-9}$ \\
\hline & 92 & $5.7 \pm 1.2 \times 10^{-9}$ & $6.2 \pm 0.5 \times 10^{-9}$ \\
\hline \multirow[t]{4}{*}{ Mo } & 4 & $<1 \times 10^{-9}$ & $1.3 \pm 0.7 \times 10^{-8}$ \\
\hline & 19 & $<3 \times 10^{-9}$ & $1.0 \pm 0.3 \times 10^{-8}$ \\
\hline & 46 & $<4 \times 10^{-9}$ & $7.6 \pm 1.1 \times 10^{-9}$ \\
\hline & 92 & $<3 \times 10^{-9}$ & $9.4 \pm 1.0 \times 10^{-9}$ \\
\hline \multirow[t]{4}{*}{$\mathrm{Ni}$} & 4 & $<6 \times 10^{-9}$ & $3.6 \pm 3.6 \times 1^{-10}$ \\
\hline & 19 & $<2 \times 10^{-9}$ & $3.3 \pm 1.8 \times 10^{-10}$ \\
\hline & 46 & $<9 \times 10^{-10}$ & $3.7 \pm 0.2 \times 10^{-10}$ \\
\hline & 92 & $<5 \times 10^{-10}$ & $4.3 \pm 0.2 \times 10^{-10}$ \\
\hline
\end{tabular}


TABLE 4.1. (contd)

Constituent (days) ANS 16.1 Leach Test Static Leach Test

$\mathrm{Cr}$

${ }^{241_{A m}}$

${ }^{137} \mathrm{Cs}$

${ }^{129} \mathrm{I}$

${ }^{90} \mathrm{Sr}$

${ }^{99} \mathrm{Tc}$

$\begin{array}{rr} & 19 \\ & 46 \\ & 92 \\ & \\ & 40 \\ & 49 \\ & 46 \\ & 92\end{array}$

4

19

46

92

4

19

46

92

\section{4}

19

46

92

4

19

46

92

4

19

46

92

4

19

46

92

4

19

46

92
$<1.3 \times 10^{-11}$

$<4.5 \times 10^{-12}$

$<2 \times 10^{-12}$

$<1 \times 10^{-12}$

$1.2 \times 10^{-11}$

$3.8 \times 10^{-12}$

$2.1 \times 10^{-12}$

$1.1 \times 10^{-9}$

$5.0 \times 10^{-10}$

$3.0 \times 10^{-10}$

-....

$3.4 \times 10^{-8}$

$4.2 \times 10^{-8}$

$3.1 \times 10^{-8}$

$5.8 \times 10^{-15}$

$3.1 \times 10^{-15}$

$2.1 \times 10^{-15}$

$3.9 \times 10^{-8}$

$2.5 \times 10^{-8}$

$4.3 \times 10^{-8}$

$<8.9 \times 10^{-11}$

$<3.2 \times 10^{-11}$

$<1.7 \times 10^{-11}$

- - . -
$<4 \times 10^{-13}$

$<1 \times 10^{-13}$

$<5 \times 10^{-13}$

$3.0 \pm 0.2 \times 10^{-14}$

9.3 to $12.8 \times 10^{-13}$

2.0 to $2.8 \times 10^{-10}$

4.5 to $7.3 \times 10^{-8}$

3.0 to $4.1 \times 10^{-16}$

4.3 to $6.4 \times 10^{-8}$

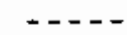

$<2.1$ to $2.9 \times 10^{-12}$ 
the range 1 to $5 \times 10^{-10} \mathrm{~cm}^{2} / \mathrm{s}$, while ${ }^{241} \mathrm{Am}$ and ${ }^{90} \mathrm{Sr}$ showed low diffusion coefficients $\left(<5 \times 10^{-12} \mathrm{~cm}^{2} / \mathrm{s}\right)$. There are very few differences in the leach rates of the anions $\left(\mathrm{TCO}_{4}^{-}, \mathrm{I}^{-}, \mathrm{Cl}^{-}, \mathrm{NO}_{2}^{-}, \mathrm{NO}_{3}^{-}\right.$, and $\left.\mathrm{F}^{-}\right)$and the cation $\mathrm{Na}$ between the two tests. Molybdenum appears to leach faster under static conditions, while Am and $\mathrm{Sr}$ leach slower under static conditions.

As was found for PSW grout (Serne et al. 1987, 1989) and cladding removal waste (CRW) grout (to be reported), iodine, technetium, nitrite, nitrate, and sodium are leached more rapidly than other species. The effective diffusivities for the 106-AN grouts are larger than those measured on PSW and CRW grouts. The cause could be that 106-AN 1iquid waste is chemically more difficult to encapsulate or that the physical structure of the 106-AN grout is more porous to water leaching than previously studied grouts. Also, the 40-day curing time is the shortest used in any of the grout leach tests, and the ending at 92 days of contact is the shortest time studied. Both facts also lead to larger effective diffusivities. That is, for periods of time up to at least 1 year, longer curing times generally result in lower leach rates, and as leach experiments are continued for periods up to 3 years, we find that the cumulative effective diffusivities continue to slowly decrease, especially for the ANS 16.1 tests.

It appears that high $\mathrm{pH}$ leaching environments will reduce the Am and $\mathrm{Sr}$ leaching, probably because of solubility considerations.

Tallent et a1. (1988) at ORNL has performed ANS 16.1 leach tests on simulated 106-AN waste that was grouted with the ratio $81 \mathrm{lb} / \mathrm{gal}$ (versus our 9 1b/gal) solid blend to liquid waste. The ORNL grout dry blend was $47 \%$ ground blast furnace slag, $47 \% \mathrm{Cl}$ ass $\mathrm{F}$ fly ash, and $6 \%$ type I-II Portland cement by weight, which differs slightly from our $47.5 \%: 47.5 \%: 5 \%$ mixture.

Table 4.2 compares average, incremental effective diffusivities calculated at ORNL with the equivalent PNL data and cumulative effective diffusivities from static tests. The leach indices for the ANS 16.1 data are also shown in Table 4.2. 
IABLE 4.2. Comparison of ORNL and PNL Leach Data

\begin{tabular}{|c|c|c|c|}
\hline \multirow[b]{2}{*}{ Species } & \multicolumn{2}{|c|}{$\begin{array}{c}\text { ANS } 16.1 \text { Leach Test } \\
\mathrm{D}_{\mathrm{e}}(\text { incrementa } 1)\end{array}$} & \multirow{2}{*}{$\begin{array}{l}\text { Static Leach Test } \\
D_{\mathrm{e}} \text { (cumulative) } \\
\text { PNL }\end{array}$} \\
\hline & ORNL & PNL & \\
\hline${ }^{99} \mathrm{Tc}$ & $1.3 \times 10^{-9(a)}$ & $4.57 \pm 8.33 \times 10^{-7}$ & 4.3 to $6.4 \times 10^{-8}$ \\
\hline $\mathrm{NO}_{3}$ & $1.3 \times 10^{-8(a)}$ & $1.06 \pm 1.14 \times 10^{-8}$ & $6.2 \pm 0.5 \times 10^{-9}$ \\
\hline $\mathrm{NO}_{2}$ & $1.0 \times 10^{-8(b)}$ & $1.29 \pm 1.27 \times 10^{-8}$ & $6.9 \pm 0.6 \times 10^{-9}$ \\
\hline$I^{2}$ & $1.6 \times 10^{-8(b)}$ & $3.40 \pm 3.80 \times 10^{-8}$ & 4.5 to $7.3 \times 10^{-8}$ \\
\hline $\mathrm{Cl}$ & $2.0 \times 10^{-8(b)}$ & $2.42 \pm 1.82 \times 10^{-8}$ & $6.9 \pm 0.6 \times 10^{-9}$ \\
\hline & Leach Indice: & (ANS 16.1 Test) & \\
\hline${ }^{99} \mathrm{Tc}$ & $9.1 \pm 0.0^{(a)}$ & $7.4 \pm 1.2$ & \\
\hline $\mathrm{NO}_{3}$ & $8.0 \pm 0.1^{(a)}$ & $8.2 \pm 0.5$ & \\
\hline $\mathrm{NO}_{2}$ & $8.0 \pm 0.1^{(b)}$ & $8.1 \pm 0.5$ & \\
\hline I & $7.8 \pm 0.1^{(b)}$ & $7.6 \pm 0.4$ & \\
\hline $\mathrm{Cl}$ & $7.7 \pm 0.2^{(b)}$ & $7.9 \pm 0.6$ & \\
\hline
\end{tabular}

(a) Tallent et a]. 1988

(b) $1988 \mathrm{draft}$ report, Oak Ridge National Laboratory

The agreement between the ORNL and PNL data for nitrate, nitrite, iodine, and chloride is excellent. The leach indices of these four anionic species hover around $8\left(D_{e}=10^{-8} \mathrm{~cm}^{2} / \mathrm{s}\right)$, which is one order-of-magnitude more favorable (leach resistant) than that required by the WHC grout formulation criteria.

There is a distinct difference in the ORNL and PNL data for Tc. The Tc diffusivity is about 350 times greater in the PNL tests. Some of the difference is likely caused by the difficulty in measuring low levels of ${ }^{99} \mathrm{Tc}$ in actual leachate that has $10^{5}$ more activity of such isotopes as ${ }^{137} \mathrm{Cs}$. The original ${ }^{99} \mathrm{Tc}$ inventory in the 106-AN waste stream is relatively small, and ${ }^{99} \mathrm{Tc}$ concentrations in the leachates are within a factor of 10 of the

(a) Riddelle, J. G. 1987. Formulation Criterion for the Hanford Grout Disposal Program. Internal Report SD-WM-SS-004, Westinghouse Hanford Company, Richland, Washington. 
background. On the other hand, ORNL spiked their simulated waste with an adequate amount of ${ }^{99} T_{c}$ to allow adequate counting of leachates. It is not known whether the addition of excess ${ }^{99}$ Tc could influence (bias) leach rate determination. Studies on the effects of varying ${ }^{99} \mathrm{Tc}$ inventories in doubleshell slurry feed grouts are under way. Uncertainty in the Tc inventory has a large effect on the calculated effective diffusivity. If the Tc concentration in the waste samples measured by WHC (Table 2.2) is used in the calculations, the effective diffusivity would decrease by more than two orders of magnitude, and the Tc leach index wouTd increase by two units. Thus, the values would be very near the ORNL values. At any rate, these preliminary studies suggest that ${ }^{99} \mathrm{Tc}$ leach rates may approach the minimum performance requirement and additional attention is warranted.

The static tests also suggest that iodine leach rates are greater under the chemical conditions observed for low flow conditions. Similar results were obtained on other leach tests using PSW (Serne et al. 1989) and CRW grouts (to be reported).

One might expect that the PNL grout at $9 \mathrm{lb} / \mathrm{gal}$ mix ratio would perform better than the ORNL grout at $8 \mathrm{lb} / \mathrm{ga}$. Leach rates for nitrate, nitrite, and chloride do not suggest that the higher solids content in the PNL grout results in increased leach resistance. Perhaps the differences in curing (PNL at room temperature versus $O R N L$ at $60^{\circ} \mathrm{C}$ ) or the use of actual tank waste has confounded the expected improvement with a larger percentage of groutforming solids in the grout mix.

\subsection{RESULTS OF EXTRACTION PROCEDURE TOXICITY TEST}

The results of the analysis of filtered leachate from the EP toxicity test are shown in Table 4.3. In most cases, the metal concentrations are below the analytical detection 1 imit, and in all cases the observed concentrations are below the regulatory limits. Thus, based on testing one sample, it appears that Tank 106-AN grout is not toxic per the EP toxicity test protocol. 
TABLE 4.3. Extraction Procedure Toxicity Results for Radioact ive Tank 106-AN Grout

\begin{tabular}{|c|c|c|}
\hline Element & $\begin{array}{c}\text { Analyzed } \\
\text { Concentration } \\
(\mathrm{mg} / \mathrm{L}) \\
\end{array}$ & $\begin{array}{c}\text { Regulatory } \\
\text { Limit } \\
\text { (mg/L) } \\
\end{array}$ \\
\hline $\mathrm{Ag}$ & $<0.01$ & 5 \\
\hline As & $<0.25$ & 5 \\
\hline $\mathrm{Ba}$ & 0.48 & 100 \\
\hline $\mathrm{Cd}$ & $<0.01$ & 1 \\
\hline $\mathrm{Cr}$ & 0.07 & 5 \\
\hline $\mathrm{Hg}$ & 0.0001 & 0.2 \\
\hline $\mathrm{Pb}$ & $<0.10$ & 5 \\
\hline Se & $<0.25$ & 1 \\
\hline
\end{tabular}

4.16 


\subsection{REFERENCES}

American Public Health Association. 1981. Standard Methods for the Examination of Water and Wastewater, eds. A. E. Greenberg, J. J. Connors, D. Jenkins, and M. H. Franson. Method \#403. American PubTic Health Association, Washington, D.C.

ANSI/ANS. 1986. Measurement of the Leachability of Solidified Low-Level Radioactive Wastes by a Short-Term Test Procedure. ANS 16.1, American Nuclear Society, La Grange Park, Illinois.

Arora, H., and R. Dayal. 1984. Solidification and Leaching of Boric Acid and Resin LWR Wastes. NUREG/CR-3909, Nuclear Regulatory Commission, Washington, D.C.

Clark, W. E. 1977. "The Isolation of Radiojodine with Portland Cement Part 1: Scoping Leach Studies." Nuclear Technology 36:215-221.

Daya1, R., H. Arora and N. Morcos. 1983. Estimation of Cesium-137 Release from Waste/Cement Composites Using Data from Smal1-Scale Specimen.

NUREG/CR-3382, Nuclear Regulatory Commission, Washington, D.C.

Daya1, R., D. C. Schweitzer and R. E. Davis, 1984. "Wet and Dry Cycle Leaching: Aspects of Research in the Unsaturated Zone." In NRC Nuclear Waste Geochemistry '83, eds., D. H. Alexander and G. F. Birchard, pp. 440-453. NUREG/CP-0052, Nuclear Regulatory Comission, Washington, D.C.

Felmy, A. R., D. C. Girvin and E. A. Jenne. 1984. MINTEQ: A Computer Program for Calculating Aqueous Geochemical Equilibria. NTIS PB 84-157148 (EPA-600/3-84-032), National Technical Information Service, Springfield, Virginia.

Godbee, H. W., 0. U. Anders and R. M. Nielson, Jr. 1980. "Application of Mass Transport Theory to the Leaching of Radionuclides from Waste Solids." Nuclear and Chemical Waste Management 1:29-35.

Kalb, P. D., and P. Columbo. 1984. "Full-Scale Leaching Study of Commercial Reactor Waste Forms." In Waste Management '84, Vol. 2, ed. R. G. Post, pp. 189-194. The University of Arizona Press, Tempe, Arizona.

Matsuzuru, H., and N. Moriyama. 1982. "Leaching Radionuclides from a Cement Composite Incorporating Evaporatory Concentrates Generated at a Pressurized Water Reactor Nuclear Power Plant." Nuclear Science and Engineering 80:14-25.

Moore, J. G., H. W. Godbee and A. H. Kibbey. 1977. "Leach Behavior of Hydrofracture Grout Incorporating Radioactive Wastes." Nuclear Technology 32:3959. 
Moriyama, N., S. Dojiri and H. Matsuzuru. 1977. "Leaching of ${ }^{137}$ Cs from the Ion Exchange Resin Incorporated in Polyethylene or Cenent Composite." Health Physics 32:549-552.

Peterson, S. R., C. J. Hostetler, W. J. Deutsch and C. E. Cowan. 1987. MINTEQ User's Manual. NUREG/CR-4808, Nuclear Regulatory Commission, Washington, D.C.

Riddelle, J. G. 1987. Formulation Criteria for the Hanford Grout Disposal Program. SD-WM-SS-004, Westinghouse Hanford Company, Richland, Washington.

Sambe11, R. A. J., C. Smitton and A. Elsden. 1982. "A Contribution Towards a Standard Leach Test for Immobilized Low and Medium Level Waste." Nuclear and Chemical Waste Management 3:125-129.

Serne, R. J., and W. J. Martin, S. B. McLaurine, S. P. Airhart, V. L. LeGore and R. L. Treat. 1987. Laboratory Leach Tests of Phosphate/Sulfate Waste Grout and Leachate Adsorption Tests Using Hanford Sediment. PNL-6019, Pacific Northwest Laboratory, Richland, Washington.

Serne, R. J., W. J. Martin, V. L. LeGore, C. L. Lindenmeier, S. B. McLaurine, P. F. C. Martin, and R. 0. Lokken. 1989. Leach Tests on Grouts Made with Actual and Trace Metal-Spiked Synthetic Phosphate/Sulfate Waste. PNL-7121, Pacific Northwest Laboratory, Richland, Washington.

Tallent, 0. K., E. W. McDanie1, G. D. Del Cul, K. E. Dodson and D. R. Trotter. 1988. "Immobijization of Technetium and Nitrate in Cement-Based Materials." Mat. Res. Soc. Symp. Proc. 12:23-32.

U.S. Environmental Protection Agency, 1982. "Test Methods for the Evaluation of Soljd Waste." Physical and Chemical Properties. SW-846, Environmental Protection Agency, Washington, D.C. 
APPENDIX A

CHEMICAL COMPOSITIONS OF LEACHATES 
IABLE A.1. Chemical Composition of Leachates from Static Leach Test (S-1)

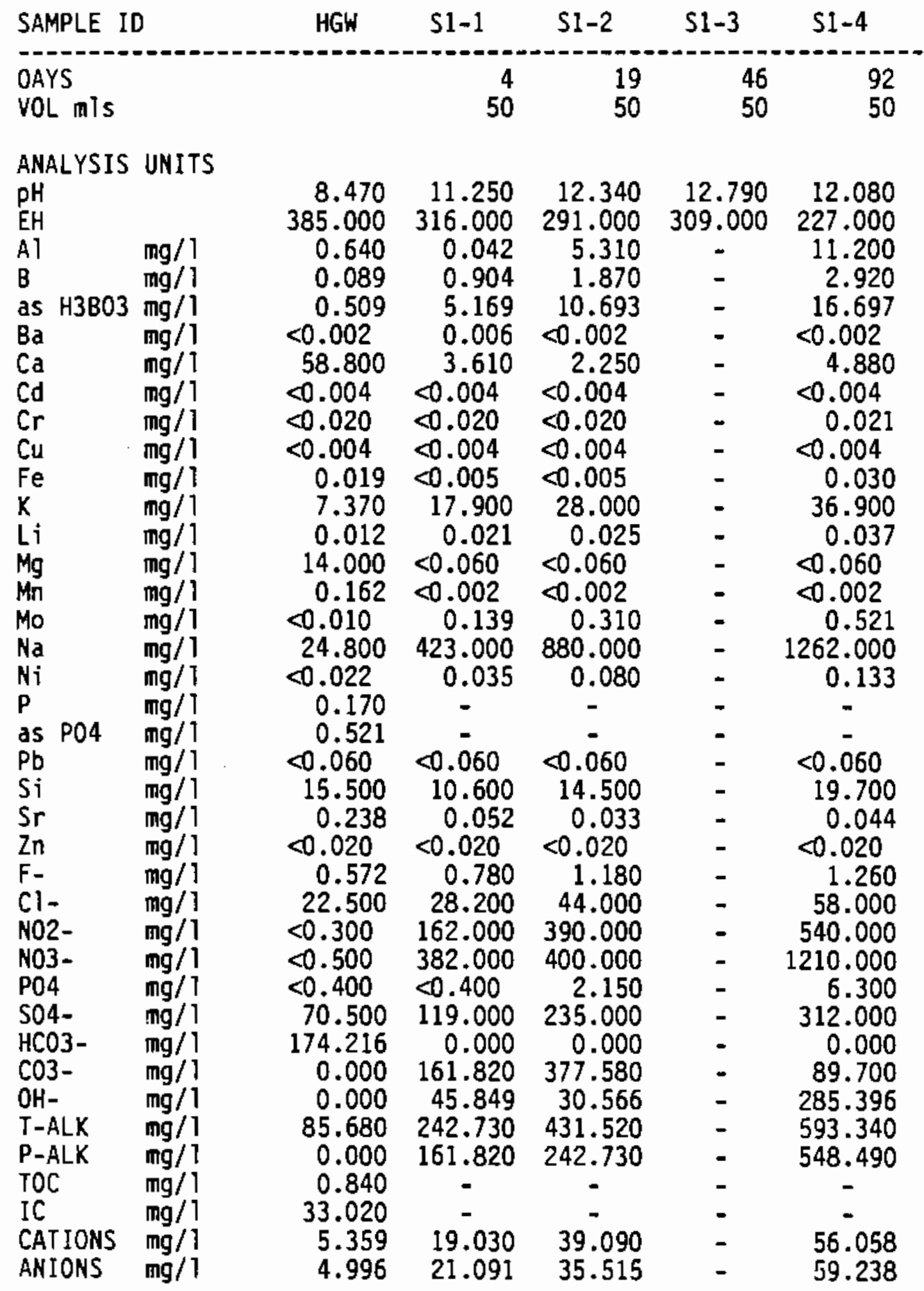


IABLE A.2. Chemical Composition of Leachates from Static Leach Test (S-2)

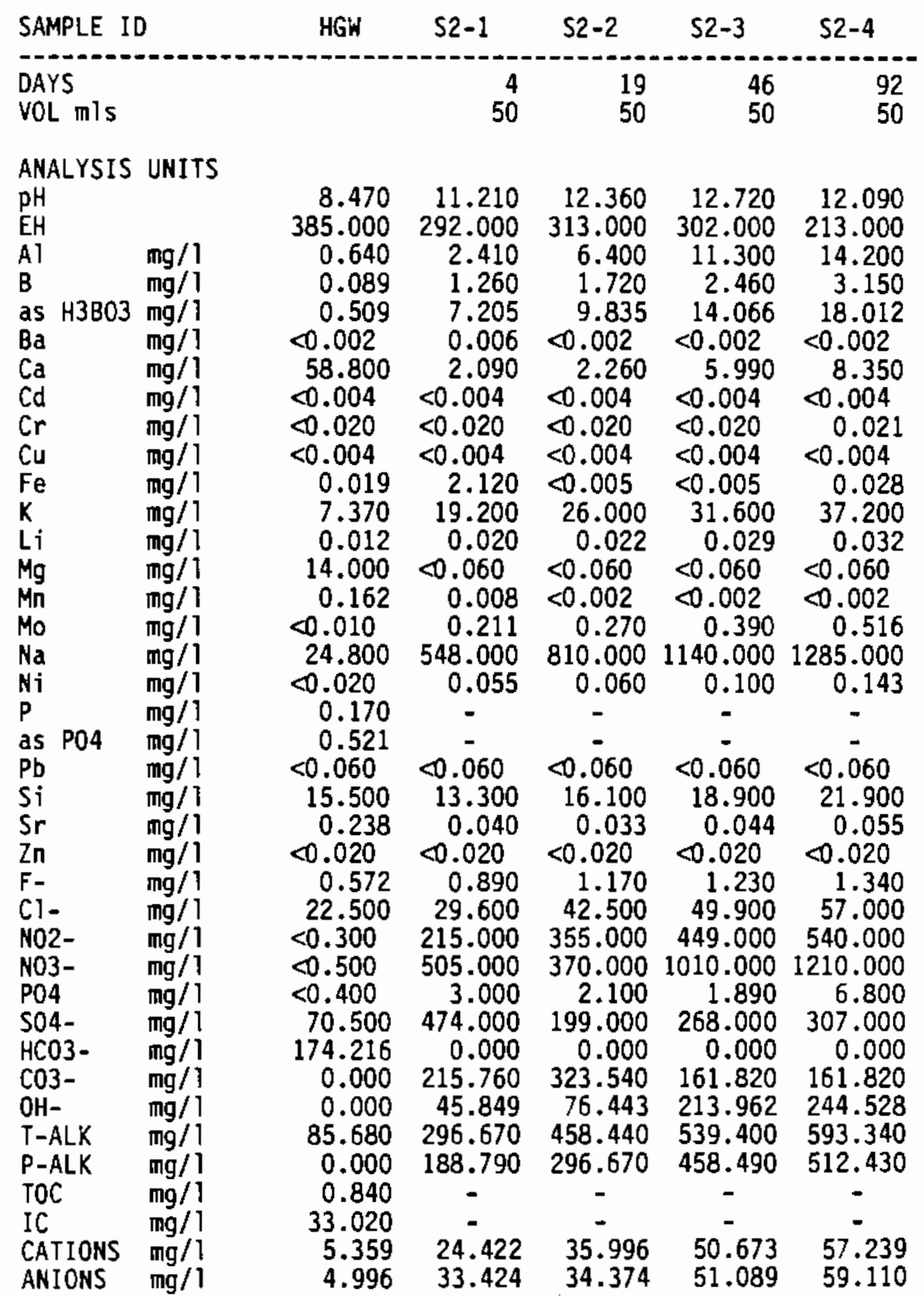


TABLE A.3. Chemical Composition of Leachates from ANS 16.1 Leach Test (A-3)

\begin{tabular}{|c|c|c|c|c|c|c|c|c|c|c|c|}
\hline \multicolumn{2}{|c|}{ SNPLE ID } & HG & A3-1 & $A 3-2$ & $A 3-3$ & $A^{3}-4$ & A3-5 & $13-6$ & $13-7$ & A3-8 & A3-9 \\
\hline \multicolumn{3}{|l|}{ DAYS } & 0.083 & 1.292 & 1.966 & 2.000 & 3.090 & 4.600 & 19.000 & 46.099 & 92.096 \\
\hline \multicolumn{2}{|l|}{ VOL is } & & 470 & 470 & 470 & 470 & 470 & 470 & 478 & 470 & 470 \\
\hline \multicolumn{12}{|c|}{ ANALYSIS LWITS } \\
\hline $\mathrm{pH}$ & & B. 470 & 9.236 & 8.840 & 9.490 & 9.390 & 9.960 & 8.740 & 11.768 & 11.758 & 9.170 \\
\hline EH & & 385.089 & 332. 096 & 337.690 & 328.080 & 333.940 & 338.980 & 388.080 & 324.000 & 319.000 & 284.080 \\
\hline A. & $\mathbf{m g} / 1$ & 0.646 & 0.353 & 0.295 & 0.237 & 8.159 & 6.103 & 9.998 & 1.330 & 6.969 & 0.199 \\
\hline B & $m g / i$ & 0.089 & 0.354 & 0.249 & 0.310 & 6.318 & 0.248 & 8.193 & 0.920 & 6.570 & 9. 476 \\
\hline as $\mathrm{H} 3803$ & $\mathbf{n g} / 1$ & 0.580 & 2.024 & 1.424 & 1.773 & 1.818 & 1.418 & 1.104 & 5.281 & 3.259 & 2.722 \\
\hline $\mathrm{Ba}$ & $m g / l$ & $<0.002$ & 0.638 & 0.037 & 0.030 & 0.025 & 0.028 & 0.031 & $<0.062$ & $\langle 6.002$ & $<6.062$ \\
\hline $\mathrm{Ca}$ & $\operatorname{mg} / 1$ & 58.800 & 29.199 & 30.500 & 25.286 & 19.689 & 23.464 & 25.690 & 1.960 & 2.878 & 2.910 \\
\hline$c d$ & $\lg / /$ & $<0.604$ & <6.064 & (1. .094 & $\langle 0.094$ & <0.084 & $<6.044$ & $\langle 0.904$ & $\langle 0.604$ & $\langle 0.984$ & $<0.004$ \\
\hline $\mathrm{Cr}$ & $\mathrm{mg} / \mathrm{l}$ & $<0.020$ & $\langle 0.02 \theta$ & $\langle 0.020$ & $<0.029$ & $<0.020$ & $\langle 0.020$ & $<0.626$ & $<0.020$ & $<9.828$ & $<0.020$ \\
\hline $\mathrm{Cu}$ & $\bullet / / 1$ & $\langle 0.014$ & $<0.904$ & $<0.094$ & $\langle 0.694$ & $\langle 0.004$ & $(0.604$ & $\langle 0.084$ & $<0.004$ & $<8.684$ & $\langle 8.084$ \\
\hline$F_{0}$ & $\mathbf{m g} / \mathbf{l}$ & 0.019 & e. 017 & 0.018 & 0.018 & 0.610 & ๑. 623 & 0.012 & $<0.065$ & <6.605 & 0.097 \\
\hline$k$ & $\lg / 1$ & 7.370 & 14.460 & B. 898 & 10.680 & 0.889 & 9.2140 & 8.900 & $16.96 \%$ & 12.006 & 11.890 \\
\hline $\mathrm{Li}$ & $n / l$ & 0.912 & $<0.694$ & 0.26 & 0.021 & 0.020 & 0.023 & 0.021 & 0.829 & 0.018 & 0.019 \\
\hline $\mathrm{Ng}$ & $\mathrm{ng} / \mathrm{l}$ & 14.900 & 11.700 & 11.266 & 9.17! & 8.120 & 8.810 & 9.870 & $<0.000$ & 0.260 & 0.909 \\
\hline Mn & $g / /$ & 0.102 & $\langle 0.612$ & $<0.002$ & $<0.002$ & $\langle 0.002$ & $\langle 6.602$ & $\langle 0.082$ & (4. 802 & $<0.942$ & $\langle 0.002$ \\
\hline No & $n g / 1$ & $<0.010$ & $\langle\bullet .11$ & $\langle 0.010$ & $\langle 0.010$ & $\langle 0.010$ & $\langle 6.110$ & $\langle 0.016$ & 0.160 & (9.810 & 6.696 \\
\hline $\mathrm{Na}$ & $\mathrm{ng} / \mathrm{l}$ & 24.860 & 143.080 & 87.890 & 142. & 149.09 & 169.94 & 89.100 & 428.080 & 291.000 & 231.006 \\
\hline $\mathrm{Ni}$ & $9 / /$ & (1. 624 & $\langle 9.024$ & <0.029 & <6. 120 & $<0.020$ & $\langle\theta .02 \theta$ & $<0.829$ & 0.040 & <0.628 & 6.027 \\
\hline$P$ & $m / /$ & 0.170 & - & - & - & - & - & - & - & - & $=$ \\
\hline as $\mathrm{PO} 4$ & $\lg / 1$ & 0.521 & - & - & - & - & - & - & - & - & - \\
\hline $\mathrm{Pb}$ & $\operatorname{gg} / 1$ & $\langle 0.860$ & <0.060 & $<0.080$ & $<6.000$ & (0.68) & $\langle 0.060$ & $\langle 0.060$ & $<0.889$ & (0.068 & $\angle \theta .0 B \theta$ \\
\hline si & $\bullet / / 1$ & 15.504 & 13.100 & 12.890 & 12.680 & 12.896 & 12.594 & 13.00 & 17.606 & 14.806 & 12.606 \\
\hline Sr & $\operatorname{gos} / 1$ & 0.238 & 1.180 & 0.171 & .141 & 6.118 & 1.135 & 6. 155 & 0.693 & 0.628 & 0.634 \\
\hline $\mathrm{Zn}$ & $\mathbf{m g} / 1$ & (4.024 & $\langle\theta .820$ & (10.020 & (0.620 & (0.020 & $\langle 0.020$ & $\langle 6.620$ & $<0.026$ & $\langle 6.020$ & $\langle 8.020$ \\
\hline F- & $\bullet g / 1$ & 0.572 & 0.876 & 0.030 & 0.880 & 6.726 & 0.764 & 0.858 & 0.890 & 0.740 & 0.896 \\
\hline $\mathrm{Cl}=$ & $g / 1$ & 22.500 & 26.284 & 24.809 & 28.400 & 28.486 & 26.800 & 28.680 & 34.500 & 28.900 & 27.606 \\
\hline NO2- & $\mathbf{l g} / 1$ & (8. 390 & 54.600 & 27.990 & 51.696 & 51.080 & 32.960 & 25.960 & 168.689 & 96.600 & 80.900 \\
\hline NOS- & $g / 1$ & $<0.500$ & 121.000 & 56.766 & 194.060 & 184.060 & 65.000 & 55.100 & 387.029 & 210.000 & 176.960 \\
\hline $\mathrm{PO4}$ & $m g / l$ & $\langle 0.490$ & $<0.406$ & $<0.480$ & $<0.486$ & $\langle 6.460$ & $<0.400$ & 10.400 & 2.056 & $\langle 0.460$ & 1.700 \\
\hline SO4- & $\ln / 1$ & 79.500 & 97.096 & 88.291 & 95.060 & 96.680 & 81.986 & 83.680 & 145.446 & 119.900 & 118.060 \\
\hline HCO3- & $\mathrm{mg} / \mathrm{I}$ & 174.216 & 131.818 & 153.537 & 164.517 & 184.517 & 184.517 & 236.318 & 0.600 & 0.000 & 0.661 \\
\hline CO3- & $g / 1$ & 6.000 & 6.006 & 0.090 & 6.089 & 9.006 & 4.000 & 0.600 & 113.268 & 97.100 & B4. 706 \\
\hline OH- & $\operatorname{co} / /$ & 0.060 & ๑. 006 & 6.000 & 9.600 & 0.986 & 6. & 0.906 & $41.27 !$ & 32.098 & 0.600 \\
\hline$T-A L K K$ & $\mathrm{~g} / \mathrm{l}$ & 65.884 & 64.739 & 76.510 & 88.910 & 89.910 & 86.910 & 113.270 & 188.690 & 153.736 & 84.739 \\
\hline$P-A L K$ & $\lg / 1$ & c. .060 & 1.090 & 6.600 & 6.900 & 1. .009 & 1.900 & 0.000 & 129.460 & 196.186 & 32.350 \\
\hline TOC & $\lg / 1$ & 0.840 & - & - & - & - & - & - & $=$ & - & - \\
\hline IC & $\mathbf{n g} / 1$ & 39.820 & - & - & - & - & - & - & - & - & - \\
\hline TIDNS & $\mathbf{m g} / \mathrm{l}$ & 5.350 & 8.962 & B. 481 & B. 445 & 7.987 & B. 888 & 6. 195 & 19.030 & 13.114 & 10.588 \\
\hline IIONS & $n g / /$ & 4.908 & 8. 070 & B. 555 & B. 244 & 8.246 & 8.955 & 7.725 & 19.818 & 13. 933 & 9.964 \\
\hline
\end{tabular}


IABLE A.4. Chemical Composition of Leachates from ANS 16.1 Leach Test (A-4)

\begin{tabular}{|c|c|c|c|c|c|c|c|c|c|c|c|}
\hline SNMLE ID & & HG & A4-1 & k4-2 & $44-3$ & $A 4-4$ & A4-6 & A4-8 & 14-7 & $A 4-8$ & A4-9 \\
\hline DAYS & & & 0.083 & 1.292 & 1.600 & 2.680 & 3.040 & 4.080 & 19.608 & 46.000 & 92.960 \\
\hline YOL 13 & & & 540 & 540 & 540 & 540 & 546 & 540 & 546 & 540 & 540 \\
\hline ALY & WITS & & & & & & & & & & \\
\hline $\mathrm{pH}$ & & 0.476 & 8.689 & 8.570 & 8.810 & 9.331 & 9.010 & 8.798 & 12.010 & 11.900 & 10.389 \\
\hline 터 & & 385.460 & 393.60 & 329. 019 & 336.040 & 332.984 & 349.601 & 366.600 & 299.608 & 315.900 & 279.800 \\
\hline AI & $\operatorname{mg} / 1$ & 0.640 & 0.370 & 0.151 & .105 & 0.203 & 0.181 & 6.689 & 2.290 & 1.480 & 0.206 \\
\hline d & $9 g / 1$ & 1.089 & 0.350 & 0.253 & 0.286 & .352 & .253 & .230 & 1.178 & 9.738 & $0.58:$ \\
\hline H3803 & $\mathrm{ng} / 1$ & 0.560 & 2.053 & 1.161 & 1.487 & 2.013 & 1.447 & 1.315 & 6.699 & 4.174 & 2.885 \\
\hline Ba & $\mathrm{mg} / 1$ & <6.012 & 1. 032 & 1.630 & 6.032 & 0.022 & 0.622 & 0.028 & $<0.002$ & $<0.692$ & $\langle 0.902$ \\
\hline 2 & $\operatorname{ng} / 1$ & 69.86 & 25.901 & 31.718 & 28.201 & 18.606 & 27,394 & 21.720 & 2.630 & 2.810 & 2. 550 \\
\hline Cd & $9 / /$ & <0. 614 & $<0.094$ & <0.004 & <e. 144 & <0.954 & <0.004 & $\langle 0.094$ & $\langle 6.684$ & $\langle 0.804$ & $\langle 8.604$ \\
\hline $\mathrm{Cr}$ & $m / /$ & $<0.620$ & $\langle 0.026$ & $\langle 0.020$ & (0.020) & $\langle 0.020$ & <0.124 & <1.026 & $<0.020$ & $\langle\theta .62 \theta$ & $\langle 0.028$ \\
\hline $\mathrm{Cu}$ & $\lg / 1$ & <t. Biat & SA.AH & $<0.064$ & (0.004 & <6. Bd4 & $\langle 6.614$ & $<0.804$ & $<0.944$ & $<0.064$ & $<8.864$ \\
\hline Fe & $19 / 1$ & 0.19 & 0.617 & 0.114 & 0.014 & 0.120 & 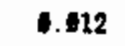 & 6.200 & $\langle 0.605$ & $\langle 0.905$ & 0.047 \\
\hline K & $\mathrm{m} / \mathrm{I}$ & 7.370 & 16.846 & 8.790 & 9.366 & 9.700 & B. 996 & 9.100 & 17.680 & 13.806 & 12.200 \\
\hline $\mathrm{Li}$ & $m g / l$ & 6.012 & 0.028 & 0.018 & 6.619 & 0.018 & 0.018 & 0.018 & 0.020 & 0.020 & 0.618 \\
\hline $\mathbf{H g}$ & $\lg / 1$ & 14.040 & 11.490 & 11.490 & 8.410 & 7.739 & 9.278 & 9.176 & $<0.880$ & .170 & 0.682 \\
\hline Wn & $1 g / 1$ & 1.162 & $<0.012$ & $(0.082$ & $\langle 6.042$ & $<\theta .012$ & $<0.002$ & $\langle 0.002$ & $\langle 6.602$ & $<0.802$ & $\langle 0.002$ \\
\hline Wo & id/l & $<0.010$ & $\langle 0.010$ & <1.016 & $\langle 0.010$ & $\langle 0.01$ & $\langle 0.010$ & $<0.016$ & 0.180 & 0.128 & 0.685 \\
\hline $\mathrm{Na}$ & $\lg / 1$ & 24.895 & 158.091 & 81.000 & 117.698 & 138.060 & 98.049 & 98.686 & 460.000 & 339.600 & 243.006 \\
\hline $\mathrm{Ni}$ & $\mathbf{m g} / 1$ & (6.028 & $<0.020$ & $\langle 6.020$ & <..626 & $<0.020$ & $<0.020$ & $\langle 0.020$ & 6.099 & 6.635 & 0.025 \\
\hline $\mathbf{P}$ & $n g / 1$ & 0.170 & - & - & - & - & - & - & - & - & - \\
\hline 18 PQ4 & $\operatorname{cg} / 1$ & 0.521 & - & - & - & - & - & - & - & - & - \\
\hline$b$ & $m / 1$ & <t.600 & <1. & $\langle 0.060$ & $<0.04$ & $<1.00$ & $<0.080$ & $\langle 0.660$ & $<0.060$ & $\langle 0.06\rangle$ & 49.869 \\
\hline$i$ & $\mathbf{a g} / 1$ & 15.610 & 12.80 & 13.190 & 12.490 & 12.490 & 12.800 & 12.880 & 18.594 & 16.390 & 12.260 \\
\hline$r$ & $m g / l$ & 0.230 & 6.150 & 0.176 & 0.148 & 0.160 & 6.147 & 6.139 & 0.040 & 0.028 & 6.632 \\
\hline $\ln$ & $\operatorname{mg} / 1$ & $<0.020$ & (0.02) & <1.020 & $<0.020$ & <1.820 & (0.020) & $<0.020$ & $<0.02 \theta$ & $<6.028$ & $\langle 0.02 \theta$ \\
\hline- & $9 / 1$ & 0.572 & 0.681 & 6.880 & 0.840 & 0.655 & 0.680 & 0.246 & 1.050 & 0.810 & 0.860 \\
\hline $\mathrm{Cl}-$ & $9 / / 1$ & 22.600 & 26.29 & 25.460 & 27.600 & 28.098 & 26.400 & 25.898 & 37.580 & 30.864 & 27.860 \\
\hline No2- & $m g / 1$ & $<0.300$ & 85.040 & 24.510 & 49.306 & 48. Best & 31.880 & 32.500 & 213.696 & 122.600 & 86.700 \\
\hline t03- & $n g / 1$ & <0.680 & 150. 640 & 54.264 & 9.600 & 185.64 & 89.094 & 72. 019 & 431.000 & 272.089 & 194.600 \\
\hline 204 & $g / 1$ & (1. 498 & $(0.46$ & $<0.400$ & $<0.490$ & $(0.496$ & $\langle 0.460$ & $<0.48$ & 2.280 & 1.070 & 1.800 \\
\hline 504- & $\lg / 1$ & 70.596 & 193.098 & 77.796 & 78.400 & 92.900 & a2. & 98.096 & 191.608 & 138.600 & 120.000 \\
\hline $4 \mathrm{COB}-$ & $=9 / 1$ & 174.210 & 07.730 & 87.738 & 175.477 & 100.078 & 87.738 & 109.678 & 9.600 & 0.090 & 49. 389 \\
\hline co3- & -g// & 0.960 & 1.001 & 6.690 & ๑.801 & 0.000 & 0.068 & 0.909 & 97.690 & 97.100 & 80.968 \\
\hline H- & $\operatorname{mg/1}$ & 0.600 & 1. 801 & 6. Bat & 0.800 & 0.000 & 9.969 & 0.000 & 50.439 & 32.690 & 0.600 \\
\hline$T-A L K$ & $\bullet / / 1$ & $85.8 B 9$ & 43. 150 & 43.150 & 88.380 & 53.948 & 43.150 & 53.940 & 186.890 & 153.738 & 165.180 \\
\hline P-ALK & $n / / 1$ & 0.000 & 0.066 & 0.006 & 0.646 & 0.900 & 6.698 & 6. 608 & 137.550 & 185.180 & 40.460 \\
\hline TOC & $\mathrm{mg} / 1$ & 0.840 & - & - & - & - & - & - & - & - & - \\
\hline IC & $\mathrm{mg} / \mathrm{l}$ & 33.026 & - & - & $=$ & - & $=$ & - & - & - & - \\
\hline CAIIONS & $m g / 1$ & 5.359 & 9.380 & 6.368 & 7.510 & 7.715 & b. 617 & 8.360 & 21.452 & 15.237 & 11.861 \\
\hline KIONS & $\ln / 1$ & 4.996 & 8. 192 & 5. 216 & 7.699 & 7.220 & 5.732 & B. 428 & 22.979 & 15.910 & 11.840 \\
\hline
\end{tabular}




\section{APPENDIX B}

CUMULATIVE FRACTION LEACHED AND

EFFECTIVE DIFFUSION COEFFICIENT DATA 
IABLE B.1-1. Nitrate $\left(\mathrm{NO}_{3}\right)$ Fraction Leached from 106-AN Grout for Static Leach Test (106S-1)

\begin{tabular}{lrrrr} 
SAMRLE & $m g$ LEACHEO & \multicolumn{1}{c}{ cIm. An/AO } & TIME days & D cum. $(<0.2)$ \\
$106 \mathrm{~S}-1$ & $2.29 \mathrm{E}+02$ & $1.10 \mathrm{E}-01$ & $4.00 \mathrm{E}+00$ & $8.58 \mathrm{E}-09$ \\
$106 \mathrm{~S}-2$ & $2.59 \mathrm{E}+02$ & $1.24 \mathrm{E}-01$ & $1.90 \mathrm{E}+01$ & $2.31 \mathrm{E}-09$ \\
$106 \mathrm{~S}-3$ & $6.39 \mathrm{E}+02$ & $3.06 \mathrm{E}-01$ & $4.50 \mathrm{E}+01$ & $7.27 \mathrm{E}-09$ \\
$106 \mathrm{~S}-4$ & $8.15 \mathrm{E}+02$ & $3.91 \mathrm{E}-01$ & $9.20 \mathrm{E}+01$ & $6.52 \mathrm{E}-09$
\end{tabular}

TABLE B.1-2. Nitrite $\left(\mathrm{NO}_{2}\right)$ Fraction Leached from 106-AN Grout for Static Leach Test (106S-1)

\begin{tabular}{rrrrr} 
SAMFL & $m g$ LEACHED & \multicolumn{1}{c}{ cLm. An $/$ AO } & TIME days & D cum. $(<0.2)$ \\
$106 \mathrm{~S}-1$ & $9.70 \mathrm{E}+0 \mathrm{t}$ & $1.0 \mathrm{EE}-01$ & $4.00 \mathrm{E}+00$ & $8.25 \mathrm{E}-09$ \\
$106 \mathrm{~S}-2$ & $2.42 \mathrm{E}+02$ & $2.68 \mathrm{E}-01$ & $1.90 \mathrm{E}+01$ & $1.30 \mathrm{E}-08$ \\
$106 \mathrm{~S}-3$ & $2.97 \mathrm{E}+02$ & $3.30 \mathrm{E}-01$ & $4.60 \mathrm{E}+01$ & $8.37 \mathrm{E}-09$ \\
$106 \mathrm{~S}-4$ & $3.74 \mathrm{EE}+02$ & $4.15 \mathrm{E}-01$ & $9.20 \mathrm{E}+01$ & $7.33 \mathrm{E}-09$
\end{tabular}

TABLE B.1-3. Chloride (C1) Fraction Leached from 106-AN Grout for Static Leach Test (106S-1)

SAMRE
$106 \mathrm{~S}-1$
$106 \mathrm{~S}-2$
$1065-3$
$106 \mathrm{~S}-4$

ing LEACHED

$3.42 \mathrm{E}+00$
$1.32 \mathrm{E}+01$
$1.67 \mathrm{E}+01$

$1.67 E+01$
$2.39 E+01$

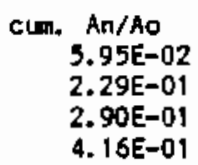

TINE doys

4. $00 \mathrm{E}+00$

$1.90 E+01$

4. $60 \mathrm{E}+0 \mathrm{O}$

9.20E+OI
0 cum. $(<0.2)$

2.52E- 09

$9 . ; 1 E-09$

$6,26 \mathrm{E}-09$

7.33E-09

TABLE B.1-4. Fluoride (F) Fraction Leached from 106-AN Grout for Static Leach Test (106S-1)

SAMRE
$1065-1$
$106 S-2$
$1065-3$
$1065-4$
mg LEACHED
1. 25E-0\%
3. $75 \mathrm{E}-\mathrm{Ot}$
4. 36E-O
4. 86E-01
Cun. An/Ao
3. $14 \mathrm{E}-02$
9. $43 \mathrm{E}-02$
1. 09E-01
1. 22E-01
TIME days
4. $00 \mathrm{E}+00$
1. $90 \mathrm{E}+01$
4. $60 \mathrm{E}+0$
9. $20 \mathrm{E}+0$ :

0 cum. $(<0.2)$

$7.01 \mathrm{E}-10$

1. $33 \mathrm{E}-09$

$7.42 \mathrm{E}-10$

$1065-4$

IABLE B.1-5. Sodium (Na) Fraction Leached from 106-AN Grout for Static Leach Test (106S-1)

SAMRE
$106 S-1$
$106 S-2$
$106 S-3$
$106 S-4$

$\mathrm{mg}$ LEACHED
$2.39 \mathrm{E}+02$
$5.33 \mathrm{E}+02$
$7.0 \mathrm{0E}+02$
$8.59 \mathrm{E}+02$
cum. An/Ao
1. 08E-01
$2.41 \mathrm{E}-01$
$3.20 \mathrm{E}-01$
3. $88 E-01$

TINE
4. DOE+0O
1. $90 \mathrm{E}+01$
4. $60 \mathrm{E}+01$
9.20E+01
0 com. $(<0.2)$
8. 32E-09
$1.05 \mathrm{E}-0 \mathrm{~B}$
$7.83 \mathrm{E}-09$
6. 53E-09


TABLE B.1-6. Molybdenum (Mo) Fraction Leached from 106-AN Grout for Static Leach Test (106S-1)

$\begin{array}{rrrrr}\text { SAMPE } & \text { mg LEADHED } & \text { cum. An/AO } & \text { TIIE days } & \text { D cum. }(<0.2) \\ 1065-1 & 7.74 E-02 & 1.06 E-01 & 4.00 \mathrm{E}+00 & 8.01 \mathrm{E}-09 \\ 1065-2 & 1.86 \mathrm{E}-01 & 2.55 \mathrm{E}-01 & 1.90 \mathrm{E}+01 & 1.19 \mathrm{E}-08 \\ 106 \mathrm{~S}-3 & 2.55 \mathrm{E}-01 & 3.50 \mathrm{E}-01 & 4.60 \mathrm{E}+01 & 6.75 \mathrm{E}-09 \\ 106 \mathrm{~S}-4 & 3.4 \mathrm{BE}-01 & 4.76 \mathrm{E}-01 & 9.20 \mathrm{I}+01 & 1.01 \mathrm{E}-08\end{array}$

TABLE B,1-7. Nicke1 (Ni) Fraction Leached from 106-AN Grout for Stat ic Leach Test (106S-1)

$\begin{array}{lrrrr}\text { SALPL } & m g \text { LEADHED } & \text { cLm. An/Ao } & \text { TIIE days } & \text { D cum. }(<0.2) \\ 1065-1 & 7.80 E-03 & 1.22 \mathrm{E}-02 & 4.00 \mathrm{E}+00 & 1.06 \mathrm{E}-10 \\ 105 \mathrm{~S}-2 & 3.54 \mathrm{E}-02 & 5.54 \mathrm{E}-02 & 1.90 \mathrm{E}+01 & 4.60 \mathrm{E}-10 \\ 1065-3 & 5.03 \mathrm{E}-02 & 7.87 \mathrm{E}-02 & 4.60 \mathrm{E}+01 & 3.84 \mathrm{E}-10 \\ 1065-4 & 7.41 \mathrm{E}-02 & 1.16 \mathrm{E}-01 & 9.20 \mathrm{E}+01 & 4.15 \mathrm{E}-10\end{array}$

TABLE B.1-8. Chromium (Cr) Fraction Leached from 106-AN Grout for Static Leach Test (106S-1)

\begin{tabular}{|c|c|c|c|c|}
\hline 65 & $\begin{array}{l}\mathrm{mg} \text { LEACHED } \\
<\quad 1.20 \mathrm{E}-02 \\
<\quad 1.30 \mathrm{E}-02 \\
<\quad 1.40 \mathrm{E}-02 \\
1.56 \mathrm{E}-02\end{array}$ & $\begin{array}{c}\text { elm. } \mathrm{An} / \mathrm{Ao} \\
7.69 \mathrm{E}-04 \\
8.33 \mathrm{E}-04 \\
8.97 \mathrm{E}-04 \\
9.99 \mathrm{E}-04\end{array}$ & $\begin{array}{r}\text { TIFE dzys } \\
4.0 \mathrm{CE}+00 \\
1.90 \mathrm{E}+01 \\
4.6 \mathrm{CE}+01 \\
9.20 \mathrm{E}+01\end{array}$ & $\begin{array}{rr}0 & \text { cum. }<0.2 \\
< & 4.21 \mathrm{E}-13 \\
< & 1.04 \mathrm{E}-13 \\
<\quad 4.98 \mathrm{E}-14 \\
& 3.09 \mathrm{E}-14\end{array}$ \\
\hline
\end{tabular}


IABLE B.2-1a. Am-241 Fraction Leached for Static Leach Test: Whole Grout in Hanford Ground Water (a11 < 1-3 values)

\begin{tabular}{|c|c|c|c|c|c|}
\hline & SAMPLE ID & uCi LEACHED & TIYE DAYS & cua An/ Ao & $D$ cun $c \backsim 2 / s e c$ \\
\hline GBAN & $1-1$ & 0. BabeE+69 & 4.00 & $0.00 \mathrm{E}+\theta 6$ & $0.00 \mathrm{E}+60$ \\
\hline & $1-2$ & O. 0960E.69 & 19.6 & D. 60E-60 & 1. \\
\hline 88 & $1-3$ & 4.5830E- 05 & 48. 01 & 3. B7E-93 & $9.29 \mathrm{E}-13$ \\
\hline
\end{tabular}

TABLE B.2-1b. Am-241 Fraction Leached for Static Leach Test: Whole Grout in Hanford Ground Water (a11 = 1-3 values)

\begin{tabular}{|c|c|c|c|c|c|}
\hline & SNMFLE ID & UC $\mathrm{i}$ LEACHED & TIUE DAYS & cun $A n / A_{0}$ & $D$ cum cue/sec \\
\hline 68. & $1-1$ & 4. $5630 \mathrm{E}-65$ & 4.89 & 3. $87 \mathrm{E}-83$ & $1.97 \mathrm{E}-11$ \\
\hline 8 & $1-2$ & 4. $9433 E-85$ & 19.60 & 4.19E-83 & $2.64 E-12$ \\
\hline 6BAN & $1-3$ & 5. 3552E-65 & 48.60 & 4. S4E-63 & 1. $28 \mathrm{E}-12$ \\
\hline
\end{tabular}

TABLE B.2-2a, Cs-137 Fraction Leached for Static Leach Test: Whole Grout in Hanford Ground Water (a $11<1-3$ values)

\begin{tabular}{|c|c|c|c|c|c|}
\hline & SNPLE ID & UC $\mathrm{i}$ LEACHED & TIUE DAYS & Cue An/Ao & $D$ cue $\mathrm{ca} 2 / \mathrm{sec}$ \\
\hline Gs & $1-1$ & 1. $8909 E+60$ & 4.60 & $0.00 E+06$ & 0. $89 E+89$ \\
\hline B & $1-2$ & $0.0980 E+60$ & 19.04 & $0.09 \mathrm{E}+16$ & 0. BaE+6S \\
\hline $36 \mathrm{~A}$ & $1-3$ & $3.3486 E+02$ & 48.96 & $5.75 E-62$ & 2. 65E-10 \\
\hline
\end{tabular}

TABLE B.2-2b. Cs-137 Fraction Leached for Static Leach Test: Whote Grout in Hanford Ground Water (a11 = 1-3 values)

\begin{tabular}{|c|c|c|c|c|c|}
\hline & SAMPLE ID & UC $\mathrm{i}$ LEACHED & TIUE DAYS & cun An/Ao & $D$ cun ca2/sec \\
\hline 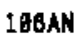 & $1-1$ & $3.3489 E+62$ & 4.00 & 5. $75 E-82$ & 2. 36E-80 \\
\hline $58 \mathrm{~A}$ & $1-2$ & 3. $627 \mathrm{E} \times 02$ & 19.00 & $6.23 E-92$ & 5. $82 E-10$ \\
\hline $6 A$ & $1-3$ & $3.9293 \mathrm{E} \times 1 / 2$ & 46.69 & 8. $75 E-62$ & 2. $82 \mathrm{E}-10$ \\
\hline
\end{tabular}

IABLE B.2-3a. I-129 Fraction Leached for Static Leach Test: Whole Grout in Hanford Ground Water (all < 1-3 values)

\begin{tabular}{|c|c|c|c|c|c|}
\hline & SNMPLE ID & UCi LERCHED & TIUE DAYS & Citu $A n / A 0$ & 0 cun cm2/sec \\
\hline 81 & $1-1$ & 1. 1680E+86 & 4.60 & A. GDE॰AS & 4. BaE 09 \\
\hline & $1-2$ & 0. $0660 E+B 6$ & 19.00 & $6.60 E+60$ & 7. 60E+80 \\
\hline 36A & $1-3$ & $3.9160 \mathrm{E}-94$ & 46. 80 & 6. 51E-81 & 4.51E-68 \\
\hline
\end{tabular}

TABLE B.2-3b. I-129 Fraction Leached for Static Leach Test: Whole Grout in Hanford Ground Water (a11 = 1-3 values)

\begin{tabular}{|c|c|c|c|c|c|}
\hline & SAMPLE ID & UCi LEACHED & TIUE DAYS & cun An/Ao & $D$ cun cas $/ \mathrm{sec}$ \\
\hline gBAN & $1-1$ & 3.9156E-84 & 4.00 & 6. $51 \mathrm{E}-61$ & 5. $19 \mathrm{E}-07$ \\
\hline $16 \mathrm{~A}$ & $1-2$ & $4.2412 E-64$ & 19.60 & 7. $66 \mathrm{E}-61$ & 1. 42E- 97 \\
\hline 36AN & $1-3$ & $4.5947 \mathrm{E}-64$ & 46.00 & $7.84 \mathrm{E}-81$ & $7.27 \mathrm{E}-98$ \\
\hline
\end{tabular}


IABLE B.2-4a. Co-60 Fraction Leached for Static Leach Test: Whole Grout in Hanford Ground Water (all $<1-3$ values)

\begin{tabular}{|c|c|c|c|c|c|}
\hline & SAMPLE ID & UC $\mathrm{i}$ LEACHED & TIUE OAYS & cun $A_{n} / A_{0}$ & $D$ cue can $/ \mathrm{sec}$ \\
\hline 61 & $1-1$ & 6. 1690E+ & 4.66 & D. 69E+60 & 1.60E+80 \\
\hline & $1-2$ & 1. $6040 \mathrm{E}+60$ & 19.80 & 0. $06 E+68$ & $0.00 E-40$ \\
\hline Bh & $1-3$ & 4.0330E-03 & 48.84 & 5. $91 E-83$ & 2.09E-12 \\
\hline
\end{tabular}

TABLE B.2-4b. Co-60 Fraction Leached for Static Leach Test: Whole Grout in Hanford Ground Water (all = 1-3 values)

\begin{tabular}{|c|c|c|c|c|c|}
\hline & SAMPE ID & UC $\mathrm{i}$ LEACHED & TIUE DAYS & cye $A n / A_{0}$ & $D$ cun en2/sec \\
\hline $18 A N$ & $1-1$ & 4.6338E-63 & 4.80 & 5. $81 E-63$ & 2. 40E-11 \\
\hline 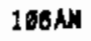 & $1-2$ & 5. 2357E-63 & 19.80 & 6. $20 E-13$ & $6.94 E-12$ \\
\hline BSAN & $1-3$ & $5.0721 E-63$ & 40.00 & 6.82E-93 & 2. BAE-12 \\
\hline
\end{tabular}

TABLE B.2-5a. Sr-90 Fraction Leached for Static Leach Test: Whole Grout in Hanford Ground Water (all < $1-3$ values)

\begin{tabular}{|c|c|c|c|c|c|}
\hline & SANPLE ID & UCi LEACHES & TIME DAYS & eun An/Ao & $0 \mathrm{cul} \mathrm{cn} 2 / \mathrm{sec}$ \\
\hline 381 & $1-1$ & 0. 6069E+60 & 4.00 & 1. 6.9E+01 & $0.60 E+64$ \\
\hline 18. & $1-2$ & 1. 0669E+66 & 19.65 & C. $20 E+90$ & 1. $.04 E+65$ \\
\hline 38 & $1-3$ & B. 7770 -as & 48.80 & 6. 91E-85 & 2.98E-16 \\
\hline
\end{tabular}

IABLE B.2-5b. Sr-90 Fraction Leached for Static Leach Test: Whole Grout in Hanford Ground Water (all = 1-3 values)

\begin{tabular}{|c|c|c|c|c|c|}
\hline & SNPLE ID & UCi LEACHED & TIUE DAYS & cus $A n /$ Ao $_{0}$ & $D$ cue $\mathrm{cm} / \mathrm{sec}$ \\
\hline 361 & $1-1$ & 6. $777 \mathrm{EE}-63$ & 4.60 & 8. $91 \mathrm{E}-65$ & 3. $44 E-16$ \\
\hline $3 \hat{A}$ & $1-2$ & 6. $777 \dot{E}-63$ & 18.00 & 8. 91E-65 & $7.26 E-18$ \\
\hline $68 \mathrm{~A}$ & $1-3$ & 6. $7779 E-63$ & 48.94 & 6. จ1E- & 2. $98 \mathrm{E}-18$ \\
\hline
\end{tabular}

TABLE B.2-6a. TC-99 Fraction Leached for Static Leach Test: Whole Grout in Hanford Ground Water (a11<1-3 values)

\begin{tabular}{|c|c|c|c|c|c|}
\hline & SAMFLE ID & UCi LEACHED & TIME DAYS & cun $\mathrm{An} / \mathrm{AO}_{0}$ & $0 \mathrm{cum} c \mathrm{~cm} / \mathrm{sec}$ \\
\hline BAH & $1-1$ & 0. .6600E+60 & 4.09 & 0. $00 \mathrm{E}+80$ & $0.60 E+00$ \\
\hline & $1-2$ & $1.6009 \mathrm{E}+60$ & 19.80 & 1. $60 E+60$ & $6.60 E+6 \theta$ \\
\hline 6ㅅN & $1-3$ & 1.0206E+60 & 46.89 & B. $24 E+01$ & 4. $28 \mathrm{E}-6 \mathrm{~B}$ \\
\hline
\end{tabular}


TABLE B.2-6b. Tc-99 Fraction Leached for Static Leach Test: Whole Grout in Hanford Ground Water (all = l-3 values)

\begin{tabular}{|c|c|c|c|c|c|}
\hline & SAMPLE ID & UCI LEACHED & TYUE DAYS & Cun $A n / A_{0}$ & $D$ evil $\mathrm{cm} 2 / \mathrm{sec}$ \\
\hline BN" & $1-1$ & 1.8268E+84 & 4.00 & $0.24 E+60$ & $4.92 \mathrm{E}-87$ \\
\hline a & $1-2$ & $1.1968 \mathrm{E}+86$ & 19.60 & $6.70 E+60$ & $1.25 E-87$ \\
\hline 18AK & $1-3$ & 1.1978E-日1 & 48.00 & $7.32 E+40$ & $8.39 E-96$ \\
\hline
\end{tabular}


IABLE B.3-1. Nitrate $\left(\mathrm{NO}_{3}\right)$ Fraction Leached from 106-AN Grout for Static Leach Test (106S-2)

SAMPLE
$10652-1$
$106 \$ 2-2$
$10652-3$
$10652-4$

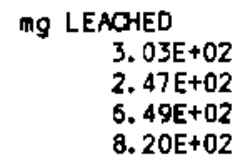

$1.91 \mathrm{E}-09$

6. $75 \mathrm{E}-09$

5. $80 \mathrm{E}-09$

IABLE B.3-2. Nitrite (NO2) Fraction Leached from 106-AN Grout for Static Leach Test (106S-2)

\begin{tabular}{|c|c|c|c|c|}
\hline 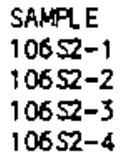 & $\begin{array}{r}\mathrm{mg} \text { LEACHED } \\
1.29 \mathrm{E}+02 \\
2.24 \mathrm{E}+02 \\
2.98 \mathrm{0}+02 \\
3.75 \mathrm{E}+02\end{array}$ & $\begin{array}{l}\text { eum. An/Ao } \\
1.36 \mathrm{E}-01 \\
2.36 \mathrm{E}-01 \\
3.15 \mathrm{E}-01 \\
3.96 \mathrm{E}-01\end{array}$ & $\begin{array}{r}\text { TIIE days } \\
4.00 E+00 \\
1.90 E+01 \\
4.60 E+01 \\
9.20 E+01\end{array}$ & $\begin{array}{r}\text { D em. }\{<0.2\} \\
\text { ?. } 32 \mathrm{E}-08 \\
9.11 \mathrm{E}-09 \\
7.85 \mathrm{E}-09 \\
6.52 \mathrm{E}-09\end{array}$ \\
\hline
\end{tabular}

TABLE B.3-3. Chloride (C1) Fraction Leached from 106-AN Grout for Static Leach Test (106S-2)

SALPE
$10652-1$
$10652-2$
$10652-3$
$10652-4$

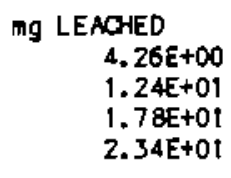

9.20E+01

6.53E-09

IABLE B.3-4. Fluoride (F) Fraction Leached from 106-AN Grout for Static Leach Test (106S-2)
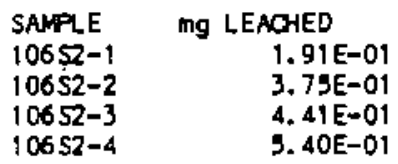
cum. An/AO 4. $56 \mathrm{E}-02$
8. $96 \mathrm{E}-02$
$1.05 \mathrm{E}-01$
$1.29 \mathrm{E}-01$
TIME days
4. $00 E+00$
$\therefore$.90E+01
4. $60 \mathrm{E}+01$
9. $20 \mathrm{E}+01$

D cum. $\{<0.2\}$

$1.48 \mathrm{E}-09$

$1.48 E-09$
$1.21 \varepsilon-09$

6. $B 9 E-10$

$10652-4$

S. $40 \mathrm{E}-\mathrm{OI}$

TABLE B.3-5. Sodium (Na) Fraction Leached from 106-AN Grout for Static Leach Test (106S-2)

\begin{tabular}{|c|c|c|c|c|}
\hline $\begin{array}{l}\text { SAPPLE } \\
106 S 2-1 \\
106 S 2-2 \\
106 \$ 2-3 \\
106 \$ 2-4\end{array}$ & $\begin{array}{r}\mathrm{mg} \mathrm{LEACHEO} \\
3.14 \mathrm{E}+02 \\
4.97 \mathrm{E}+02 \\
7.35 \mathrm{E}+02 \\
8.77 \mathrm{E}+02\end{array}$ & $\begin{array}{l}\text { cuns An/Ao } \\
1.35 \mathrm{E}-01 \\
2.14 \mathrm{E}-01 \\
3.17 \mathrm{E}-01 \\
3.78 \mathrm{E}-01\end{array}$ & $\begin{array}{r}\text { TIME days } \\
4.00 E+00 \\
1.90 E+01 \\
4.60 E+01 \\
9.20 E+01\end{array}$ & $\begin{array}{r}\text { D cum: }(<0.2) \\
1.31 \mathrm{E}-08 \\
7.49 \mathrm{E}-09 \\
7.83 \mathrm{E}-09 \\
5.80 \mathrm{E}-09\end{array}$ \\
\hline
\end{tabular}


TABLE B.3-6. Molybdenum (Mo) Fraction Leached from 106-AN Grout for Static Leach Test (106S-2)

$\begin{array}{lrrrr}\text { SAMPLE } & \mathrm{mg} L E A C H E D & \text { cum. An/AO } & \text { TIME days } & \text { D cum. }(<0.2) \\ 10652-1 & 1.21 \mathrm{E}-01 & 1.57 \mathrm{E}-01 & 4.00 \mathrm{E}+00 & 1.75 \mathrm{E}-0 \mathrm{0} \\ 10652-2 & 1.66 \mathrm{E}-01 & 2.16 \mathrm{E}-01 & 1.90 \mathrm{0}+01 & 8.30 \mathrm{E}-09 \\ 10652-3 & 2.31 \mathrm{E}-01 & 3.26 \mathrm{E}-01 & 4.60 \mathrm{E}+01 & 8.37 \mathrm{E}-09 \\ 10652-4 & 3.46 \mathrm{E}-01 & 4.49 \mathrm{E}-01 & 9.20 \mathrm{E}+01 & 8.66 \mathrm{E}-09\end{array}$

TABLE B.3-7. Nickel (Ni) Fraction Leached from 106-AN Grout for Static Leach Test (106S-2)

$\begin{array}{lrrrr}\text { SAMPLE } & \text { mg LEACHED } & \text { cum. An/AO } & \text { TIME days } & \text { D cum. }(<0.2) \\ 10652-1 & 1.98 E-02 & 2.96 \mathrm{E}-02 & 4.00 \mathrm{E}+00 & 6.22 \mathrm{E}-10 \\ 105 \mathrm{SZ}-2 & 2.44 \mathrm{E}-02 & 3.55 \mathrm{E}-02 & 1.90 \mathrm{2}+01 & 2.00 \mathrm{E}-10 \\ 10652-3 & 5.03 \mathrm{E}-02 & 7.51 \mathrm{E}-02 & 4.60 \mathrm{E}+01 & 3.50 \mathrm{E}-10 \\ 10652-4 & 8.00 \mathrm{E}-02 & 1.19 \mathrm{E}-01 & 9.20 \mathrm{E}+01 & 4.42 \mathrm{E}-10\end{array}$

TABLE B.3-8. Chromium (Cr) Fraction Leached from 106-AN Grout for Static Leach Test (106S-2)

$\begin{array}{lrrrr}\text { SAMPE } & \text { mg LEACHED } & \text { cum. An/AO } & \text { TIME days } & \text { D cum. }<0.2 \\ 106 S 2-1 & <1.20 \mathrm{E}-02 & 7.33 \mathrm{E}-04 & 4.00 \mathrm{E}+00< & 3.83 \mathrm{E}-13 \\ 10652-2 & <1.30 \mathrm{E}-02 & 7.94 \mathrm{E}-04 & 1.90 \mathrm{E}+01< & 9.46 \mathrm{E}-14 \\ 106 \mathrm{S2}-3 & <1.40 \mathrm{E}-02 & 8.55 \mathrm{E}-04 & 4.60 \mathrm{E}+01< & 4.53 \mathrm{E}-14 \\ 106 \mathrm{S2}-4 & 1.56 \mathrm{E}-02 & 9.53 \mathrm{E}-04 & 9.20 \mathrm{E}+01 & 2.81 \mathrm{E}-14\end{array}$


TABLE B.4-1. Nitrate $\left(\mathrm{NO}_{3}\right)$ Fraction Leached from 106-AN Grout for ANS 16.1 Leach Test (106AN-3)

\begin{tabular}{|c|c|c|}
\hline 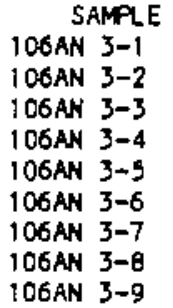 & $\begin{array}{c}\text { mg LEACHED } \\
6.51 E+01 \\
3.03 E+0: \\
5.59 E+01 \\
5.59 E+01 \\
3.48 E+01 \\
2.94 E+01 \\
1.98 E+02 \\
1.13 E+02 \\
9.48 E+01\end{array}$ & $\begin{array}{l}\text { An } / A O \\
3.53 E-02 \\
1.65 E-02 \\
3.03 E-02 \\
3.03 E-02 \\
1.89 E-02 \\
1.60 E-02 \\
1.07 E-01 \\
6.14 E-02 \\
5.14 E-02\end{array}$ \\
\hline
\end{tabular}

$\begin{array}{lr}\text { cutr. An } / \text { Ao } & \text { TiNE days } \\ 3.53 \mathrm{E}-02 & 8.33 \mathrm{E}-02 \\ 5.1 \text { EE-02 } & 2.90 \mathrm{E}-01 \\ 6.21 \mathrm{E}-02 & 1.00 \mathrm{E}+00 \\ 1.12 \mathrm{E}-01 & 2.00 \mathrm{E}+00 \\ 1.31 \mathrm{E}-01 & 3.00 \mathrm{E}+00 \\ 1.47 \mathrm{E}-01 & 4.00 \mathrm{E}+00 \\ 2.55 \mathrm{E}-01 & 1.90 \mathrm{E}+01 \\ 3.16 \mathrm{E}-01 & 4.60 \mathrm{E}+01 \\ 3.67 \mathrm{E}-01 & 9.20 \mathrm{E}+01\end{array}$

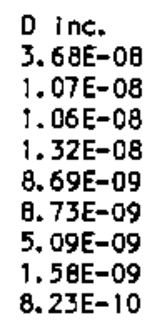
D cum $<0.2$
3. $6 \mathrm{aE}-08$
2. 27 E-08
1. $66 \mathrm{E}-08$
1. 55E-08
1. $4 \div E-O B$
$1.33 \mathrm{E}-0 \mathrm{~B}$
$1.09 \mathrm{E}-08$
$7.27 E-09$
5. $11 E-09$

TABLE B.4-2. Nitrite (NO2) Fraction Leached from 106-AN Grout for ANS 16.1 Leach Test (106AN-3)

\begin{tabular}{|c|c|c|c|c|c|c|}
\hline \begin{tabular}{ll}
\multicolumn{2}{r}{ SAMPLE } \\
$106 \mathrm{AN}$ & $3-1$ \\
$106 \mathrm{AN}$ & $3-2$ \\
$106 \mathrm{AN}$ & $3-3$ \\
$106 \mathrm{AN}$ & $3-4$ \\
$106 \mathrm{AN}$ & $3-5$ \\
$106 \mathrm{AN}$ & $3-6$ \\
$106 \mathrm{AN}$ & $3-7$ \\
$106 \mathrm{AN}$ & $3-8$ \\
$106 \mathrm{AN}$ & $3-9$
\end{tabular} & $\begin{array}{c}\text { mg LEACHED } \\
2.90 \mathrm{E}+01 \\
1.46 \mathrm{E}+01 \\
2.74 \mathrm{E}+01 \\
2.74 \mathrm{E}+01 \\
1.76 \mathrm{E}+01 \\
1.3 \mathrm{EE}+01 \\
9.06 \mathrm{E}+01 \\
5.17 \mathrm{E}+01 \\
4.35 \mathrm{E}+01\end{array}$ & $\begin{array}{l}\mathrm{An} / \mathrm{AO} \\
3.64 \mathrm{E}-02 \\
1.63 \mathrm{E}-02 \\
3.44 \mathrm{E}-02 \\
3.44 \mathrm{E}-02 \\
2.21 \mathrm{E}-02 \\
1.74 \mathrm{E}-02 \\
1.14 \mathrm{E}-01 \\
6.49 \mathrm{E}-02 \\
5.46 \mathrm{E}-02\end{array}$ & $\begin{array}{c}\text { Eum. An } / \text { AO } \\
3.64 \mathrm{E}-02 \\
5.47 \mathrm{E}-02 \\
8.91 \mathrm{E}-02 \\
1.23 \mathrm{E}-01 \\
1.46 \mathrm{E}-01 \\
1.63 \mathrm{E}-01 \\
2.77 \mathrm{E}-0 ! \\
3.41 \mathrm{E}-0 ! \\
3.96 \mathrm{E}-01\end{array}$ & $\begin{array}{l}\text { TiEe days } \\
\text { 8. 33E-02 } \\
2.90 \mathrm{E}-01 \\
1.00 \mathrm{E}+00 \\
2.00 \mathrm{E}+00 \\
3.00 \mathrm{E}+00 \\
4.00 \mathrm{E}+00 \\
1.90 \mathrm{E}+01 \\
4.60 \mathrm{E}+01 \\
9.20 \mathrm{E}+01\end{array}$ & $\begin{array}{l}0 \text { inc. } \\
4.53 \mathrm{E}-08 \\
1.53 \mathrm{E}-08 \\
1.58 \mathrm{E}-08 \\
1.96 \mathrm{E}-08 \\
1.38 \mathrm{E}-08 \\
1.20 \mathrm{E}-08 \\
6.62 \mathrm{E}-09 \\
2.04 \mathrm{E}-09 \\
1.08 \mathrm{E}-09\end{array}$ & $\begin{array}{r}0 \text { cum }<0.2 \\
4.53 \mathrm{E}-08 \\
2.94 \mathrm{E}-08 \\
2.26 \mathrm{E}-08 \\
2.17 \mathrm{E}-08 \\
2.01 \mathrm{E}-08 \\
1.69 \mathrm{E}-08 \\
1.40 \mathrm{E}-08 \\
8.37 \mathrm{E}-09 \\
6.52 \mathrm{E}-09\end{array}$ \\
\hline
\end{tabular}

TABLE B.4-3. Chloride (C7) Fraction Leached from 106-AN Grout for ANS 16.I Leach Test (106AN-3)

\begin{tabular}{|c|c|c|c|c|c|c|c|}
\hline \begin{tabular}{ll}
\multicolumn{2}{c}{ SAMPLE } \\
106AN $3-1$ \\
106AN $3-2$ \\
106AN $3-3$ \\
106 AN $3-4$ \\
106 AN $3-5$ \\
106 AN $3-6$ \\
106 AN $3-7$ \\
106AN $3-8$ \\
106 AN $3-9$
\end{tabular} & $\begin{array}{c}\text { mg LEACHED } \\
2.00 \mathrm{E}+00 \\
1.24 \mathrm{E}+00 \\
2.11 \mathrm{E}+00 \\
2.11 \mathrm{E}+00 \\
2.21 \mathrm{E}+00 \\
1.99 \mathrm{E}+00 \\
6.46 \mathrm{E}+00 \\
3.46 \mathrm{E}+00 \\
2.43 \mathrm{E}+00\end{array}$ & $\begin{array}{l}\text { An/Ao } \\
3.93 \mathrm{E}-02 \\
2.45 \mathrm{E}-02 \\
4.15 \mathrm{E}-02 \\
4.15 \mathrm{E}-02 \\
4.36 \mathrm{E}-02 \\
3.72 \mathrm{E}-02 \\
1.28 \mathrm{E}-01 \\
6.81 \mathrm{E}-02 \\
4.79 \mathrm{E}-02\end{array}$ & cusm. & $\begin{array}{l}\text { An/Ao } \\
3.93 \mathrm{E}-02 \\
6.38 \mathrm{E}-02 \\
1.05 \mathrm{E}-01 \\
1.47 \mathrm{E}-01 \\
1.90 \mathrm{E}-01 \\
2.28 \mathrm{E}-01 \\
3.55 \mathrm{E}-01 \\
4.23 \mathrm{E}-01 \\
4.71 \mathrm{E}-01\end{array}$ & $\begin{array}{r}\text { TIME days } \\
8.33 E-02 \\
2.90 E-01 \\
1.00 E+00 \\
2.00 E+00 \\
3.00 E+00 \\
4.00 E+00 \\
1.90 E+01 \\
4.60 E+01 \\
9.20 E+01\end{array}$ & $\begin{array}{l}0 \text { Inc. } \\
5.30 \mathrm{E}-08 \\
2.73 \mathrm{E}-08 \\
2.30 \mathrm{E}-08 \\
2.86 \mathrm{E}-08 \\
5.36 \mathrm{E}-08 \\
5.50 \mathrm{E}-08 \\
8.34 \mathrm{E}-09 \\
2.25 \mathrm{E}-09 \\
8.27 \mathrm{E}-10\end{array}$ & $\begin{array}{r}\text { D cum }<0.2 \\
5.30 \mathrm{E}-08 \\
4.00 \mathrm{E}-08 \\
3.16 \mathrm{E}-08 \\
3.07 \mathrm{E}-08 \\
3.44 \mathrm{E}-08 \\
4.33 \mathrm{E}-08 \\
2.4 \mathrm{BE}-00 \\
1.47 \mathrm{E}-08 \\
9.62 \mathrm{E}-09\end{array}$ \\
\hline
\end{tabular}

TABLE B.4-4. Fluoride (F) Fraction Leached from 106-AN Grout for ANS 16.1 Leach Test (106AN-3)

\begin{tabular}{|c|c|c|c|c|c|c|c|}
\hline \begin{tabular}{ll}
\multicolumn{2}{c}{ SANLE } \\
106AN & $3-1$ \\
106AN & $3-2$ \\
$106 A N$ & $3-3$ \\
$106 A N$ & $3-4$ \\
$106 A N$ & $3-5$ \\
$106 A N$ & $3-6$ \\
$106 A N$ & $3-7$ \\
$106 A N$ & $3-8$ \\
106AN $3-9$
\end{tabular} & $\begin{array}{c}\text { Mg LEACHEO } \\
5.29 \mathrm{E}-02 \\
3.13 \mathrm{E}-02 \\
5.83 \mathrm{E}-02 \\
7.99 \mathrm{E}-02 \\
6.91 \mathrm{E}-02 \\
4.21 \mathrm{E}-02 \\
1.93 \mathrm{E}-01 \\
9.07 \mathrm{E}-02 \\
1.51 \mathrm{E}-02\end{array}$ & $\begin{array}{l}\text { An/Ao } \\
1.50 \mathrm{E}-02 \\
8.90 \mathrm{E}-03 \\
1.66 \mathrm{E}-02 \\
2.27 \mathrm{E}-02 \\
1.96 \mathrm{E}-02 \\
1.20 \mathrm{E}-02 \\
5.49 \mathrm{E}-02 \\
2.5 \mathrm{EE}-02 \\
4.30 \mathrm{E}-03\end{array}$ & cum. & $\begin{array}{l}A n / A O \\
1.50 \mathrm{E}-02 \\
2.39 \mathrm{E}-02 \\
4.05 \mathrm{E}-02 \\
6.32 \mathrm{E}-02 \\
8.2 \mathrm{EE}-02 \\
9.48 \mathrm{E}-02 \\
1.50 \mathrm{E}-01 \\
1.76 \mathrm{E}-01 \\
1.00 \mathrm{E}-01\end{array}$ & $\begin{array}{r}\text { TIME days } \\
8.33 E-02 \\
2.90 \mathrm{E}-01 \\
1.00 \mathrm{E}+00 \\
2.00 \mathrm{E}+00 \\
3.00 \mathrm{E}+00 \\
4.00 \mathrm{E}+00 \\
1.90 \mathrm{E}+01 \\
4.50 \mathrm{E}+01 \\
9.20 \mathrm{E}+01\end{array}$ & $\begin{array}{l}D \text { Inc. } \\
6.67 \mathrm{E}-09 \\
3.12 \mathrm{E}-09 \\
3.17 \mathrm{E}-09 \\
7.39 \mathrm{E}-09 \\
9.38 \mathrm{E}-09 \\
4.90 \mathrm{E}-09 \\
1.33 \mathrm{E}-09 \\
2.78 \mathrm{E}-10 \\
5.75 \mathrm{E}-12\end{array}$ & $\begin{array}{l}0 \text { cum }<0.2 \\
6.67 \mathrm{E}-09 \\
4.65 \mathrm{E}-09 \\
4.03 \mathrm{E}-09 \\
4.91 \mathrm{E}-09 \\
5.62 \mathrm{E}-09 \\
5.52 \mathrm{E}-09 \\
2.90 \mathrm{E}-09 \\
1.65 \mathrm{E}-09 \\
8.64 \mathrm{E}-10\end{array}$ \\
\hline
\end{tabular}




\section{TABLE B.4-5. Sodium (Na) Fraction Leached from 106-AN Grout for ANS 16.1 Leach Test (106AN-3)}

\begin{tabular}{|c|c|c|c|c|c|c|}
\hline $\begin{array}{l}\text { SAMPLE } \\
\text { 106AN } 3-1 \\
106 \text { AN } 3-2 \\
106 \text { AN } 3-3 \\
106 \text { AN } 3-4 \\
106 \text { AN } 3-5 \\
106 \text { AN } 3-6 \\
106 \text { AN } 3-7 \\
106 \text { AN } 3-8 \\
106 \text { AN } 3-9\end{array}$ & $\begin{array}{c}\mathrm{mg} \text { LEACHED } \\
6.3 \mathrm{BE}+01 \\
3.39 \mathrm{E}+01 \\
6.33 \mathrm{E}+01 \\
6.22 \mathrm{E}+01 \\
4.55 \mathrm{E}+01 \\
3.47 \mathrm{E}+01 \\
2.17 \mathrm{E}+02 \\
1.44 \mathrm{E}+02 \\
1.11 \mathrm{E}+02\end{array}$ & $\begin{array}{l}\mathrm{An} / \mathrm{AO} \\
3.27 \mathrm{E}-02 \\
1.74 \mathrm{E}-02 \\
3.24 \mathrm{E}-02 \\
3.18 \mathrm{E}-02 \\
2.33 \mathrm{E}-02 \\
1.78 \mathrm{E}-02 \\
1.11 \mathrm{E}-01 \\
7.36 \mathrm{E}-02 \\
5.70 \mathrm{E}-02\end{array}$ & $\begin{aligned} \text { cun. } A n / A O \\
3.27 \mathrm{E}-02 \\
5.00 \mathrm{E}-02 \\
8.24 \mathrm{E}-02 \\
1.14 \mathrm{E}-01 \\
1.38 \mathrm{E}-01 \\
i .55 \mathrm{E}-01 \\
2.56 \mathrm{E}-01 \\
3.40 \mathrm{E}-01 \\
3.97 \mathrm{E}-01\end{aligned}$ & $\begin{array}{c}\text { TIME days } \\
\text { a. } 33 E-02 \\
2.90 E-0: \\
1.00 E+00 \\
2.00 E+00 \\
3.00 E+00 \\
4.00 E+00 \\
1.90 E+0 ! \\
4.60 E+01 \\
9.20 E+01\end{array}$ & $\begin{array}{l}0 \text { Inc. } \\
3.65 \mathrm{E}-08 \\
1.38 \mathrm{E}-08 \\
1.40 \mathrm{E}-08 \\
1.68 \mathrm{E}-08 \\
1.53 \mathrm{E}-08 \\
1.25 \mathrm{E}-08 \\
6.30 \mathrm{E}-09 \\
2.63 \mathrm{E}-09 \\
1.17 \mathrm{E}-09\end{array}$ & $\begin{array}{r}\text { D cum }<0.2 \\
3.65 E-08 \\
2.46 E-08 \\
1.94 \mathrm{E}-08 \\
1.86 \mathrm{E}-08 \\
1.80 \mathrm{E}-08 \\
1.72 \mathrm{E}-08 \\
1.30 \mathrm{E}-08 \\
8.37 \mathrm{E}-09 \\
6.52 \mathrm{E}-09\end{array}$ \\
\hline
\end{tabular}

TABLE B.4-6. Molybdenum (Mo) Fraction Leached from 106-AN Grout for ANS 16.1 Leach Test (106AN-3)

\begin{tabular}{|c|c|c|c|c|c|c|c|c|c|c|}
\hline $\begin{array}{l}\text { SAMPLE } \\
\text { 106AN } 3-1 \\
\text { 106AN } 3-2 \\
106 \text { AN } 3-3 \\
106 \text { AN } 3-4 \\
106 \text { AN } 3-5 \\
106 \text { AN } 3-6 \\
\text { 106AN } 3-7 \\
\text { 106AN } 3-8 \\
\text { IO6AN } 3-9\end{array}$ & $\begin{array}{l}-< \\
< \\
< \\
< \\
<\end{array}$ & $\begin{array}{l}\text { mg LEACHED } \\
5.40 E-03 \\
5.40 E-03 \\
5.40 E-03 \\
5.40 E-03 \\
5.40 E-03 \\
5.40 E-03 \\
8.10 E-02 \\
5.40 E-03 \\
4.32 E-02\end{array}$ & $\begin{array}{l}\text { An } / A O \\
8.31 E-03 \\
8.31 E-03 \\
8.31 E-03 \\
8.31 E-03 \\
8.31 E-03 \\
8.31 E-03 \\
1.25 E-01 \\
8.31 E-03 \\
6.65 E-02\end{array}$ & cum. & $\begin{array}{l}\text { An/Ao } \\
8.31 \mathrm{E}-03 \\
1.66 \mathrm{E}-02 \\
2.49 \mathrm{E}-02 \\
3.32 \mathrm{E}-02 \\
4.15 \mathrm{E}-02 \\
4.98 \mathrm{E}-02 \\
1.74 \mathrm{E}-01 \\
1.83 \mathrm{E}-01 \\
2.49 \mathrm{E}-01\end{array}$ & $\begin{array}{r}\text { TIME days } \\
\text { 8.33E-02 } \\
2.90 \mathrm{E}-01 \\
1.00 \mathrm{E}+00 \\
2.00 \mathrm{E}+00 \\
3.00 \mathrm{E}+00 \\
4.00 \mathrm{E}+00 \\
1.90 \mathrm{E}+01 \\
4.60 \mathrm{E}+01 \\
9.20 \mathrm{E}+01\end{array}$ & $\begin{array}{l}< \\
< \\
< \\
< \\
< \\
<\end{array}$ & $\begin{array}{l}\text { D } 1 \mathrm{nc} . \\
2.04 \mathrm{E}-09 \\
2.72 \mathrm{E}-09 \\
7.97 \mathrm{E}-10 \\
9.89 \mathrm{E}-10 \\
1.68 \mathrm{E}-09 \\
2.36 \mathrm{E}-09 \\
6.86 \mathrm{E}-09 \\
2.89 \mathrm{E}-11 \\
1.38 \mathrm{E}-09\end{array}$ & $\begin{array}{l}< \\
< \\
< \\
< \\
< \\
< \\
<\end{array}$ & $\begin{array}{r}0 \text { cum }<0.2 \\
2.04 E-09 \\
2.34 E-09\end{array}$ \\
\hline
\end{tabular}

\section{IABLE B.4-7. Nicke1 (Ni) Fraction Leached from 106-AN Grout for} ANS 16.1 Leach Test (106AN-3)

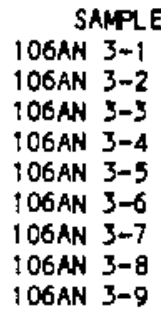

SARPLE

106AN 3-1

106 AN 3-2

106 AN 3-4

106 AN 3-5

106 AN 3-7

106AN 3-9

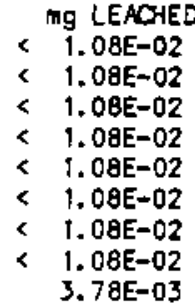

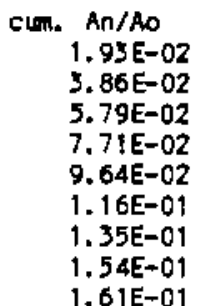

TIME day 5
$8.33 E-02$
$2.90 E-01$
$1.00 E+00$
$2.00 E+00$
$3.00 E+00$
$4.00 E+00$
$1.90 E+01$
$4.60 E+01$
$9.20 E+01$

$1.93 E-02$

1. $93 \mathrm{E}-02$

$1.93 E-02$

1. 93E-02

$1.93 \mathrm{E}-02$

1. 93 E-02

$6.75 \mathrm{E}-03$
D Inc.

0 cin $<0.2$

\begin{tabular}{|c|c|c|}
\hline $\begin{array}{l}\text { I ne. } \\
.27 \mathrm{E}-08 \\
.70 \mathrm{E}-08 \\
.98 \mathrm{E}-09 \\
.18 \mathrm{E}-09 \\
.05 \mathrm{E}-08 \\
.48 \mathrm{E}-08 \\
.91 \mathrm{E}-10\end{array}$ & $\begin{array}{l}< \\
< \\
<\end{array}$ & $\begin{array}{l}c u<0 \\
1.27 E-0 \\
1.46 E-0 \\
9.54 E-0\end{array}$ \\
\hline
\end{tabular}

TABLE B.4-8. Chromium (Cr) Fraction Leached from 106-AN Grout for ANS 16.1 Leach Test (106AN-3)

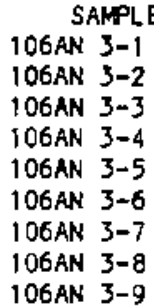

An/Ao

7. $83 \mathrm{E}-04$

7. $83 \mathrm{E}-04$

7. $83 \mathrm{E}-04$

7. 83E-04

7. $83 \mathrm{E}-04$

7. $83 \mathrm{E}-04$

7. $63 E-04$

$7.83 E-04$

7. $83 \mathrm{E}-04$

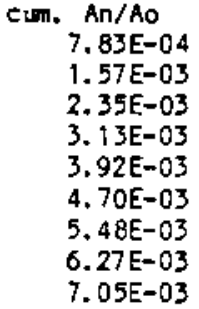

TINE days
$8.33 E-02$
$2.90 E-01$
$1.00 E+00$
$2.00 E+00$
$3.00 E+00$
$4.00 E+00$
$1.90 E+01$
$4.60 E+01$
$9.20 E+01$

0 inc.

cum $<0.2$

2. $10 \mathrm{E}-11<2.10 \mathrm{E}-11$

2. $80 E-11<2.41 E-11$

$8.21 \mathrm{E}-12<1.57 \mathrm{E}-11$

$1.02 \mathrm{E}-11<1.40 \mathrm{E}-11$

$1.73 \mathrm{E}-11<1.46 \mathrm{E}-11$

2. $44 \mathrm{E}-11<1.57 \mathrm{E}-11$

$3.14 \mathrm{E}-13<4.51 \mathrm{E}-12$

$2.98 \mathrm{BE}-13<2.43 \mathrm{E}-12$

$2.22 \mathrm{E}-13<1.54 \mathrm{E}-12$ 
IABLE B.5-1. Nitrate $\left(\mathrm{NO}_{3}\right)$ Fraction Leached from 106-AN Grout for ANS 16.1 Leach Test (106AN-4)

SAMPLE
106AN $4-1$
106 AN $4-2$
$106 A N 4-3$
106 AN $4-4$
$106 A N 4-5$
$106 A N 4-6$
$106 A N 4-7$
$106 A N 4-8$
$106 A N 4-9$

mg LEACHED
$8.07 E+01$
$2.90 E+01$
$4.83 E+01$
$5.64 E+01$
$3.70 E+01$
$3.86 E+01$
$2.32 E+02$
$1.47 E+02$
$1.04 E+02$

An $/ A O$
3.5 BE-02
$1.29 E-02$
$2.15 E-02$
$2.51 E-02$
$1.64 E-02$
$1.71 E-02$
$1.03 E-01$
$6.51 E-02$
$4.64 E-02$

cun. An/AO
$3.58 \mathrm{E}-02$
$4.87 \mathrm{E}-02$
$7.02 \mathrm{E}-02$
$9.52 \mathrm{E}-02$
$1.12 \mathrm{E}-01$
$1.29 \mathrm{E}-01$
$2.32 \mathrm{E}-01$
$2.97 \mathrm{E}-01$
$3.43 \mathrm{E}-01$
TIME days
8. 33E-02
2. $90 \mathrm{E}-01$
1. $00 E+00$
2. $00 E+00$
3. $00 E+00$
4. $00 E+00$
1. 90E+01
4. $60 E+01$

0 inc.

4. 34E-08

$7.48 \mathrm{E}-09$

6. $09 E-09$

$1.03 \mathrm{E}-08$

$7.52 \mathrm{E}-09$

1. 15E-08

5. 39E-09

2. $03 E-09$

9. $20 \mathrm{E}+01 \quad 7.68 \mathrm{E}-10$
0 cum. $(<0.2)$
4. 34E-08
2. $30 \mathrm{E}-08$
$1.39 \mathrm{E}-08$
$1.28 E-08$
$1.17 \mathrm{E}-08$
1. $17 \mathrm{E}-08$
$9.11 \mathrm{E}-09$
$6.75 \mathrm{E}-09$
4. $19 \mathrm{E}-09$

\section{IABLE B.5-2. Nitrite $\left(\mathrm{NO}_{2}\right)$ Fraction Leached from 106-AN Grout for} ANS 16.1 Leach Test (106AN-4)

SAMPE
106AN $4-1$
106AN 4-2
106AN $4-3$
106AN $4-4$
106AN $4-5$
106AN $4-6$
106AN $4-7$
106AN $4-8$
106AN $4-9$

mg LEACHED
$3.49 \mathrm{E}+0: 1$
$1.31 \mathrm{E}+01$
$2.16 \mathrm{E}+01$
$2.36 \mathrm{E}+01$
$1.70 \mathrm{E}+01$
$1.74 \mathrm{E}+01$
$1.15 \mathrm{E}+02$
$0.57 \mathrm{E}+01$
$4.67 \mathrm{E}+01$

$\begin{array}{lr}\text { An/Ao } & \text { cum. } \begin{array}{l}\text { An/AO } \\ 3.59 \mathrm{E}-02\end{array} \\ 3.59 \mathrm{E}-02 \\ 1.34 \mathrm{E}-02 & 4.93 \mathrm{E}-02 \\ 2.22 \mathrm{E}-02 . & 7.15 \mathrm{E}-02 \\ 2.65 \mathrm{E}-02 & 9.80 \mathrm{E}-02 \\ 1.75 \mathrm{E}-02 & 1.15 \mathrm{E}-01 \\ 1.79 \mathrm{E}-02 & 1.33 \mathrm{E}-01 \\ 1.18 \mathrm{E}-01 & 2.51 \mathrm{E}-01 \\ 6.75 \mathrm{E}-02 & 3.19 \mathrm{E}-01 \\ 4.79 \mathrm{E}-02 & 3.67 \mathrm{E}-01\end{array}$

TIE days
$8.33 E-02$
$2.90 \mathrm{E}-01$
$1.00 \mathrm{E}+00$
$2.00 \mathrm{E}+00$
$3.00 \mathrm{E}+00$
$4.00 \mathrm{E}+00$
$1.90 \mathrm{E}+01$
$4.60 \mathrm{E}+01$
$9.20 \mathrm{E}+01$
D lne.
4. 35E-00
8. $13 E-09$
$0.51 E-09$
$1.15 E-08$
0.51E-09
$1.25 \mathrm{E}-08$
7. $05 \mathrm{E}-09$
2. $19 \mathrm{E}-09$
8. $20 \mathrm{E} \rightarrow 10$
0 cum. $(<0.2)$
$4.35 \mathrm{E}-08$
2.36E-08
1. 44E-08
1. $35 \mathrm{E}-08$
$1.25 \mathrm{E}-08$
$1.25 \mathrm{E}-08$
$1.09 \mathrm{E}-08$
7. $83 \mathrm{E}-09$
5. $11 E-09$

\section{IABLE B.5-3. Chloride (C1) Fraction Leached from 106-AN Grout for ANS 16.1 Leach Test (106AN-4)}

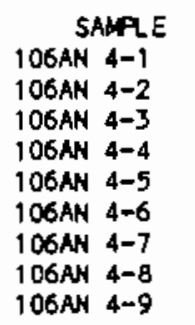

mg 2 EACHED
$2.00 \mathrm{E}+00$
$1.57 \mathrm{E}+00$
$2.75 \mathrm{E}+00$
$1.89 \mathrm{E}+00$
$2.11 \mathrm{E}+00$
$1.78 \mathrm{E}+00$
$8.10 \mathrm{E}+00$
$4.48 \mathrm{E}+00$
$2.86 \mathrm{E}+00$

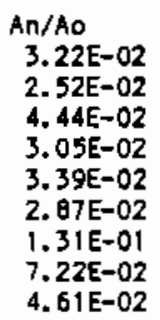
cum. $A n / A_{0}$
3. 22E-02
$5.74 E-02$
1.02E-01
$1.32 \mathrm{E}-01$
$1.66 \mathrm{E}-01$
$1.95 \mathrm{E}-01$
3. $25 E-01$
3. $98 \mathrm{E}-01$
4. 44E-O1

TIME doys
a. $33 \mathrm{E}-02$
2. $90 \mathrm{E}-01$
$1.00 E+00$
2. $00 E+\infty O$
3. $00 \mathrm{E}+00$
4. $00 \mathrm{E}+00$
1. $90 \mathrm{E}+01$
4. $60 \mathrm{E}+01$
9. $20 \mathrm{E}+01$

D Ine.

3. $55 \mathrm{E}-08$

2. $91 \mathrm{E}-08$

2. $64 \mathrm{E}-08$

$1.54 \mathrm{E}=08$

3. $25 \mathrm{E}-08$

$3.27 \mathrm{E}-08$

0.73E-09

2. 53E-09

7. $68 \mathrm{E}-10$
0 cum. $(<0.2)$

3. 55E-08

3. $24 \mathrm{E}-0 \mathrm{O}$

2. $96 \mathrm{E}-08$

2. $49 \mathrm{E}-08$

2. 63E-08

2. $71 \mathrm{E}-08$

2. $03 \mathrm{E}-08$

$1.30 \mathrm{E}-08$

a. $19 \mathrm{E}-09$

TABLE B.5-4. Fluoride (F) Fraction Leached from 106-AN Grout for ANS 16.1 Leach Test (106AN-4)

\begin{tabular}{|c|c|c|c|c|c|c|}
\hline $\begin{array}{l}\text { SANIZE } \\
106 A N 4-1 \\
106 A N 4-2 \\
106 A N 4-3 \\
106 A N 4-4 \\
106 A N 4-5 \\
106 A N 4-6 \\
106 A N 4-7 \\
106 A N 4-8 \\
106 A N 4-9\end{array}$ & $\begin{array}{c}\mathrm{mg} \text { LEACHED } \\
5.83 E-02 \\
4.75 \mathrm{E}-02 \\
3.67 \mathrm{E}-02 \\
4.21 \mathrm{E}-02 \\
5.83 \mathrm{E}-02 \\
3.67 \mathrm{E}-02 \\
2.58 \mathrm{E}-01 \\
1.29 \mathrm{E}-01 \\
4.75 \mathrm{E}-02\end{array}$ & $\begin{array}{l}\text { An/Ao } \\
1.36 E-02 \\
1.11 E-02 \\
8.54 E-03 \\
9.80 E-03 \\
1.36 E-02 \\
8.54 E-03 \\
6.00 E-02 \\
2.99 E-02 \\
1.11 E-02\end{array}$ & $\begin{array}{c}\text { eum. An/AO } \\
1.36 \mathrm{E}-02 \\
2.46 \mathrm{E}-02 \\
3.32 \mathrm{E}-02 \\
4.29 \mathrm{E}-02 \\
5.65 \mathrm{E}-02 \\
6.51 \mathrm{E}-02 \\
1.25 \mathrm{E}-01 \\
1.55 \mathrm{E}-01 \\
1.66 \mathrm{E}-01\end{array}$ & $\begin{array}{r}\text { TIME doys } \\
\text { 8. 33E-02 } \\
2.90 \mathrm{E}-01 \\
1.00 \mathrm{E}+00 \\
\text { 2. } 00 \mathrm{E}+00 \\
3.00 \mathrm{E}+00 \\
\text { 4. } 00 \mathrm{E}+00 \\
1.90 \mathrm{E}+01 \\
4.60 \mathrm{E}+01 \\
9.20 \mathrm{E}+01\end{array}$ & $\begin{array}{l}0 \text { iле. } \\
5.43 \mathrm{E}-09 \\
4.81 \mathrm{E}-09 \\
8.42 \mathrm{E}-10 \\
1.37 \mathrm{E}-09 \\
4.48 \mathrm{E}-09 \\
2.50 \mathrm{E}-09 \\
1.59 \mathrm{E}-09 \\
3.74 \mathrm{E}-10 \\
3.80 \mathrm{E}-11\end{array}$ & $\begin{array}{l}D \text { cum }<0.2 \\
5.43 E-09 \\
5.14 E-09 \\
2.70 E-09 \\
2.27 E-09 \\
2.62 E-09 \\
2.60 E-09 \\
2.02 E-09 \\
1.28 E-09 \\
7.36 E-10\end{array}$ \\
\hline
\end{tabular}




\section{IABLE B.5-5. Sodium (Na) Fraction Leached from 106-AN Grout for ANS 16.1 Leach Test (106AN-4)}

\begin{tabular}{|c|c|c|c|c|c|c|}
\hline $\begin{array}{l}\text { SAMFLE } \\
\text { 106AN } 4-1 \\
\text { 106AN } 4-2 \\
\text { 106AN } 4-3 \\
\text { IO6AN } 4-4 \\
\text { 106AN } 4-5 \\
\text { 106AN } 4-6 \\
\text { 106AN } 4-7 \\
\text { 106AN } 4-8 \\
\text { 106AN } 4-9\end{array}$ & $\begin{array}{c}\text { mg LEACHED } \\
7.19 \mathrm{E}+01 \\
3.0 \mathrm{E}+01 \\
4.98 \mathrm{9}+01 \\
6.11 \mathrm{E}+01 \\
3.95 \mathrm{E}+01 \\
3.99 \mathrm{E}+0 ! \\
2.46 \mathrm{E}+02 \\
1.70 \mathrm{E}+02 \\
1.3 \mathrm{BE}+02\end{array}$ & $\begin{array}{l}\mathrm{An} / \mathrm{AO} \\
3.01 \mathrm{E}-02 \\
1.29 \mathrm{E}-02 \\
2.09 \mathrm{E}-02 \\
2.56 \mathrm{E}-02 \\
1.66 \mathrm{E}-02 \\
1.67 \mathrm{E}-02 \\
1.03 \mathrm{E}-02 \\
7.11 \mathrm{E}-02 \\
4.94 \mathrm{E}-02\end{array}$ & $\begin{array}{c}\text { cun. Ano } \\
3.01 \mathrm{E}-02 \\
4.30 \mathrm{E}-02 \\
6.39 \mathrm{E}-02 \\
\text { 8.95E-02 } \\
1.06 \mathrm{E}-01 \\
1.23 \mathrm{E}-01 \\
2.26 \mathrm{E}-01 \\
2.97 \mathrm{E}-01 \\
3.46 \mathrm{E}-01\end{array}$ & $\begin{array}{r}\text { TIVE days } \\
8.33 \mathrm{E}-02 \\
2.90 \mathrm{E}-01 \\
1.00 \mathrm{E}+00 \\
2.00 \mathrm{E}+00 \\
3.00 \mathrm{E}+00 \\
4.00 \mathrm{E}+00 \\
1.90 \mathrm{E}+01 \\
4.60 \mathrm{E}+01 \\
9.20 \mathrm{E}+01\end{array}$ & $\begin{array}{l}0 \text { ine. } \\
3.11 \mathrm{E}-08 \\
7.62 \mathrm{E}-09 \\
5.82 \mathrm{E}-09 \\
1.09 \mathrm{E}-08 \\
7.74 \mathrm{E}-09 \\
1.11 \mathrm{E}-08 \\
5.43 \mathrm{E}-09 \\
2.45 \mathrm{E}-09 \\
8.80 \mathrm{E}-10\end{array}$ & $\begin{array}{l}D_{\text {c cum }}<0.2 \\
3.11 \mathrm{E}-08 \\
1.82 \mathrm{E}-08 \\
1.16 \mathrm{E}-08 \\
1.14 \mathrm{E}-08 \\
1.07 \mathrm{E}-08 \\
1.07 \mathrm{E}-08 \\
9.11 \mathrm{E}-09 \\
6.75 \mathrm{E}-09 \\
4.79 \mathrm{E}-09\end{array}$ \\
\hline
\end{tabular}

TABLE B.5-6. Molybdenum (Mo) Fraction Leached from 106-AN Grout for ANS 16.1 Leach Test (106AN-4)

\begin{tabular}{|c|c|c|c|c|c|c|c|}
\hline 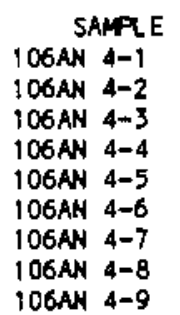 & $\begin{array}{l}< \\
< \\
< \\
< \\
<\end{array}$ & $\begin{array}{l}\text { mg LEACHEO } \\
5.40 \mathrm{E}-03 \\
5.40 \mathrm{E}-03 \\
5.40 \mathrm{E}-03 \\
5.40 \mathrm{E}-03 \\
5.40 \mathrm{E}-03 \\
5.40 \mathrm{E}-03 \\
9.18 \mathrm{E}-02 \\
5.94 \mathrm{E}-02 \\
4.05 \mathrm{E}-02\end{array}$ & $\begin{array}{l}\text { An/AO } \\
6.84 E-03 \\
6.84 \mathrm{E}-03 \\
6.84 \mathrm{E}-03 \\
6.84 \mathrm{E}-03 \\
6.84 \mathrm{E}-03 \\
6.84 \mathrm{E}-03 \\
1.16 \mathrm{E}-01 \\
7.52 \mathrm{E}-02 \\
5.13 \mathrm{E}-02\end{array}$ & $\begin{array}{r}\text { eum. An/Ao } \\
6.84 \mathrm{E}-03 \\
1.37 \mathrm{E}-02 \\
2.05 \mathrm{E}-02 \\
2.73 \mathrm{E}-02 \\
3.42 \mathrm{E}-02 \\
4.10 \mathrm{E}-02 \\
1.57 \mathrm{E}-01 \\
2.32 \mathrm{E}-01 \\
2.84 \mathrm{E}-01\end{array}$ & $\begin{array}{r}\text { TILE days } \\
8.33 E-02 \\
2.90 E-01 \\
1.00 E+00 \\
2.00 E+00 \\
3.00 E+00 \\
4.00 E+00 \\
1.90 E+01 \\
4.60 E+01 \\
9.20 E+01\end{array}$ & $\begin{aligned} & \text { D inc. } \\
< & 1.38 \mathrm{EE}-09 \\
< & 1.64 \mathrm{E}-09 \\
< & 5.39 \mathrm{E}-10 \\
< & 6.69 \mathrm{E}-10 \\
< & 1.14 \mathrm{E}-09 \\
< & 1.60 \mathrm{E}-09 \\
& 5.96 \mathrm{E}-09 \\
& 2.37 \mathrm{E}-09 \\
& 8.19 \mathrm{E}-10\end{aligned}$ & $\begin{aligned} & D \text { cum }<0.2 \\
< & 1.38 \mathrm{E}-09 \\
< & 1.58 \mathrm{E}-09 \\
< & 1.03 \mathrm{E}-09 \\
< & 9.19 \mathrm{E}-10 \\
< & 9.57 \mathrm{E}-10 \\
< & 1.03 \mathrm{E}-09 \\
< & 3.20 \mathrm{E}-09 \\
< & 3.76 \mathrm{E}-09 \\
< & 2.90 \mathrm{E}-09\end{aligned}$ \\
\hline
\end{tabular}

IABLE B.5-7. Nickel (Ni) Fraction Leached from 106-AN Grout for ANS 16.I Leach Test (106AN-4)

\begin{tabular}{|c|c|c|c|c|c|c|c|}
\hline 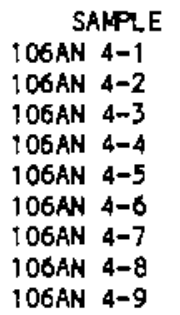 & $\begin{array}{l}< \\
< \\
< \\
< \\
<\end{array}$ & $\begin{array}{l}\text { mg LEACHED } \\
1.08 E-02 \\
1.08 \mathrm{E}-02 \\
1.08 \mathrm{E}-02 \\
1.08 \mathrm{~B}-02 \\
1.08 \mathrm{E}-02 \\
1.08 \mathrm{E}-02 \\
1.03 \mathrm{E}-02 \\
8.10 \mathrm{E}-03 \\
2.70 \mathrm{E}-03\end{array}$ & $\begin{array}{l}\text { An/Ao } \\
1.57 \mathrm{E}-02 \\
1.57 \mathrm{E}-02 \\
1.57 \mathrm{E}-02 \\
1.57 \mathrm{E}-02 \\
1.57 \mathrm{E}-02 \\
1.57 \mathrm{E}-02 \\
1.49 \mathrm{E}-02 \\
1.17 \mathrm{E}-02 \\
3.91 \mathrm{E}-03\end{array}$ & $\begin{array}{c}\text { cum. An } \\
1.57 \mathrm{E}-02 \\
3.13 \mathrm{E}-02 \\
4.70 \mathrm{E}-02 \\
6.26 \mathrm{E}-02 \\
7.03 \mathrm{E}-02 \\
9.39 \mathrm{E}-02 \\
1.09 \mathrm{E}-01 \\
1.21 \mathrm{E}-01 \\
1.24 \mathrm{E}-01\end{array}$ & $\begin{array}{l}\text { TINE days } \\
\text { 8.33E-02 } \\
2.90 E-01 \\
1.00 E+00 \\
2.00 E+00 \\
3.00 E+00 \\
4.00 E+00 \\
1.90 E+01 \\
4.60 E+01 \\
9.20 E+01\end{array}$ & $\begin{aligned} & \text { D inc. } \\
< & 8.38 \mathrm{EE}-09 \\
< & 1.12 \mathrm{E}-08 \\
< & 3.28 \mathrm{E}-09 \\
< & 4.07 \mathrm{E}-09 \\
< & 0.91 \mathrm{E}-09 \\
< & 9.73 \mathrm{E}-09 \\
& 1.73 \mathrm{E}-10 \\
& 6.69 \mathrm{E}-11 \\
& 5.53 \mathrm{E}-12\end{aligned}$ & $\begin{aligned} & D \text { cum }<0.2 \\
< & 8.38 \mathrm{E}-09 \\
< & 9.63 \mathrm{E}-09 \\
< & 6.29 \mathrm{E}-09 \\
< & 5.59 \mathrm{E}-09 \\
< & 5.82 \mathrm{E}-09 \\
< & 6.29 \mathrm{E}-09 \\
< & 1.78 \mathrm{E}-09 \\
< & 9.00 \mathrm{E}-10 \\
< & 4.80 \mathrm{E}-10\end{aligned}$ \\
\hline
\end{tabular}

IABLE B.5-8. Chromium (Cr) Fraction Leached from 106-AN Grout for ANS 16.1 Leach Test (106AN-4)

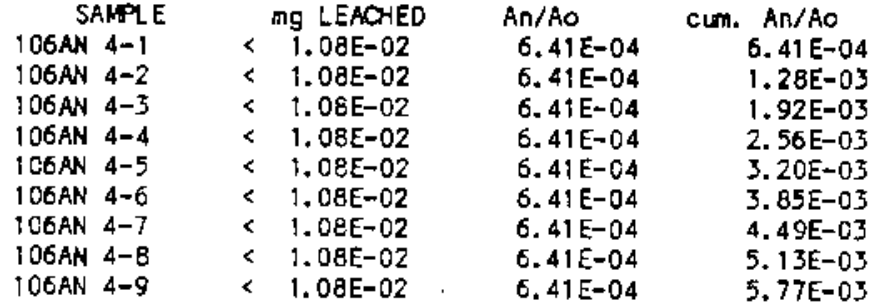

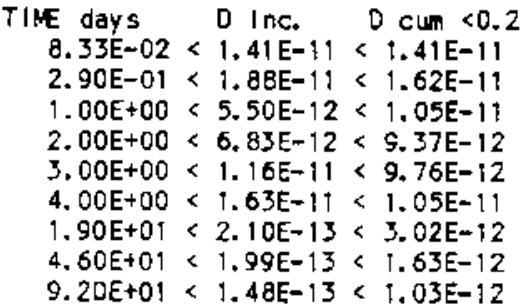


TABLE B.6-1. CS-137 Fraction Leached for ANS 16.1 Leach Test: Whole Grout In Hanford Ground Water (I06AN 4-1)

\begin{tabular}{|c|c|c|c|c|c|c|c|c|}
\hline & SAMPLE ID & TOT. LEACH (Mn) & CUI. LEACH & TINE DAYS & An/ ho & evan An/tho & 0 ine. $\cos 2 / \operatorname{soc}$ & $D$ cus en2/sec \\
\hline $106 \mathrm{AN}$ & $4-1$ & 89.18 & 89.18 & 0. 18 & $1.42 \mathrm{E}-82$ & $1.42 E-82$ & 6. $90 \mathrm{E}-69$ & $8.98 \mathrm{E}-69$ \\
\hline $106 \mathrm{AN}$ & $4-2$ & 27.85 & 117.13 & .29 & $4.4 E-85$ & $1.88 \mathrm{E}-62$ & $8.97 \mathrm{E}-10$ & $3.41 \mathrm{E}-99$ \\
\hline $166 \mathrm{AN}$ & $4-3$ & 40.17 & 183.30 & 1.60 & $7.34 \mathrm{E}-03$ & $2.86 E-42$ & $7.21 E-10$ & $1.92 \mathrm{E}-69$ \\
\hline $166 \mathrm{AN}$ & $4-4$ & 34.20 & 197.68 & 2.60 & $5.45 E-03$ & $3.14 E-12$ & 4. $93 \mathrm{E}-10$ & $1.41 \mathrm{E}-6 \mathrm{~g}$ \\
\hline $166 \mathrm{AN}$ & $4-5$ & 22.79 & 220.20 & 3.6 & $3.81 E-63$ & $3.5 \% E-62$ & $3.67 \mathrm{E}-10$ & $1.17 \mathrm{E}-99$ \\
\hline $10 B A N$ & $4-8$ & 23.40 & 243.86 & 4.60 & $3.72 \mathrm{E}-\mathbf{6 3}$ & $3.87 \mathrm{E}-62$ & $5.50 E-10$ & $1.07 \mathrm{E}-69$ \\
\hline $106 \mathrm{AN}$ & $4-7$ & 118.34 & 362.60 & 19.60 & $1.88 E-62$ & $5.78 E-62$ & $1.81 E-10$ & $4.97 \mathrm{E}-18$ \\
\hline $106 \mathrm{AN}$ & $4-8$ & 74.84 & 438.84 & 48.66 & $1.19 E-92$ & 6. $95 E-62$ & 8. $87 E-11$ & $2.99 \mathrm{E}-10$ \\
\hline
\end{tabular}

IABLE B.6-2. Co-60 Fraction Leached for ANS 16.1 Leach Test: Whole Grout In Hanford Ground Water (106AN 4-1)

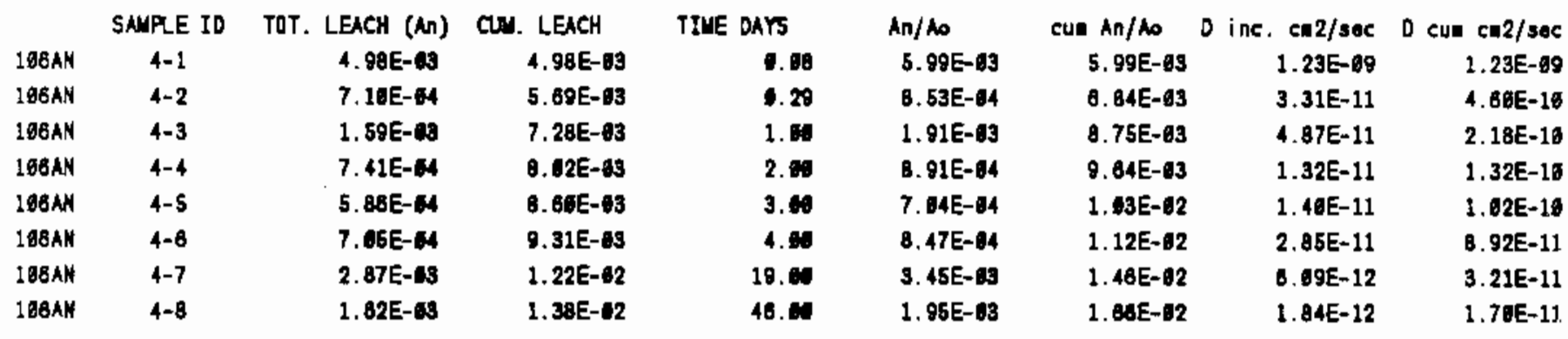

IABLE B.6-3. Sr-90 Fraction Leached for ANS 16.1 Leach Test: Whole Grout In Hanford Ground Water (106AN 4-1)

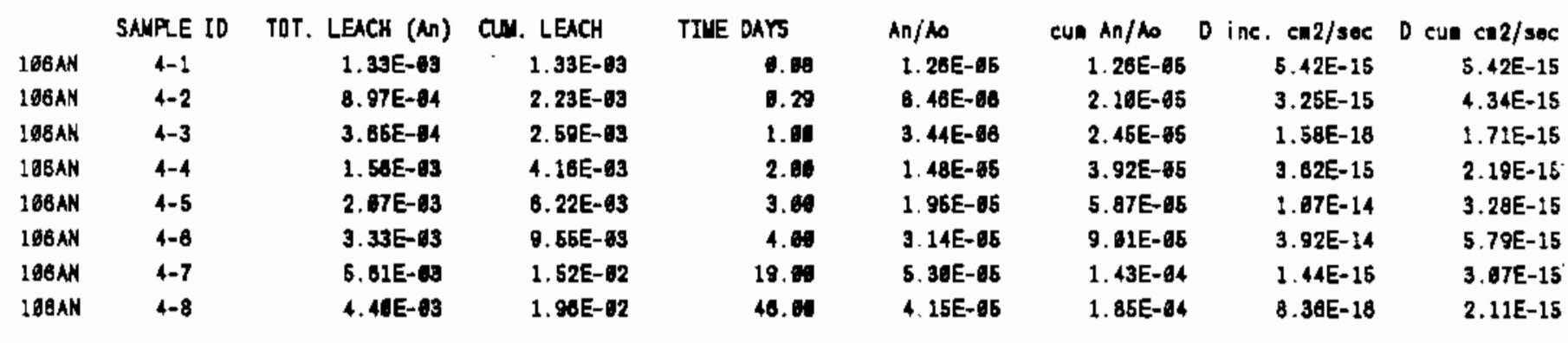


TABLE B.6-4. I-129 Fraction Leached for ANS 16.1 Leach Test:

Whole Grout In Hanford Ground Water (106AN 4-1)

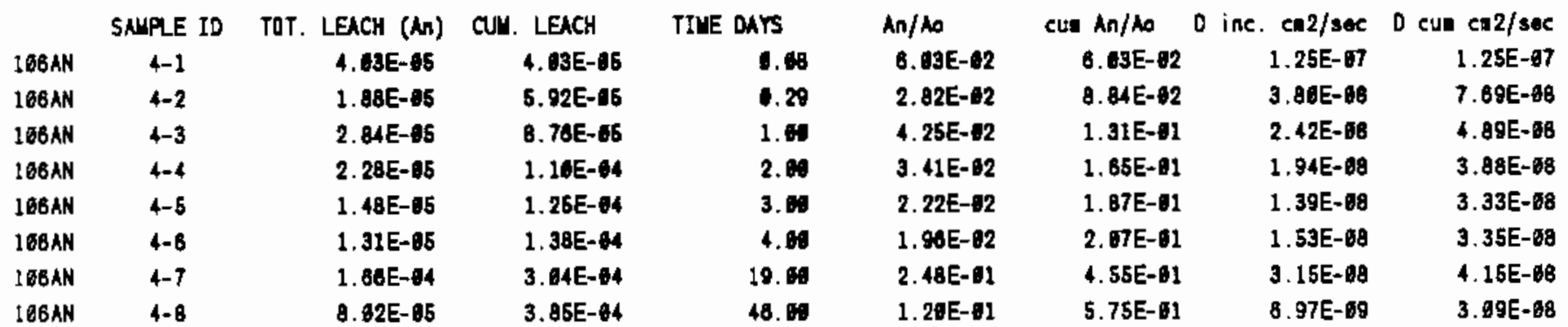

TABLE B.6-5. TC-99 Fraction Leached for ANS 16.1 Leach Test: Whole Grout In Hanford Ground Water (106AN 4-1)

$\begin{array}{lc} & \text { SAMPE I0 } \\ \text { 168AN } & 4-1 \\ \text { 166AN } & 4-2 \\ 1 \text { 16BAN } & 4-3 \\ 166 A N & 4-4 \\ 166 A N & 4-5 \\ 166 A N & 4-B \\ 166 A N & 4-7 \\ 166 A N & 4-8\end{array}$

\begin{tabular}{|c|c|}
\hline $\begin{array}{c}\text { LEACH (An) } \\
2.44 E-13\end{array}$ & $\begin{array}{l}\text { CUY. LEACH } \\
\text { 2.04E-63 }\end{array}$ \\
\hline $1.16 \mathrm{E}-63$ & 3.19E-03 \\
\hline 2. $37 E-63$ & 5. $58 \mathrm{AE}-03$ \\
\hline B. 56E- 82 & 7. $19 E-12$ \\
\hline 3. $58 E-62$ & 1. $07 E-41$ \\
\hline $1.14 E-92$ & t. 18E- 1 \\
\hline 2. 39E- 92 & $1.42 \mathrm{E}-\mathrm{-11}$ \\
\hline 5. $68 \mathrm{~B}-92$ & 1.93E-01 \\
\hline
\end{tabular}

TIME OAYS
0.69
0.29
1.00
2.06
3.60
4.60
19.60
46.09

An/Ao
$1.15 \mathrm{E}-62$
B. $49 \mathrm{E}-03$
$1.34 \mathrm{E}-92$
$3.70 \mathrm{E}-11$
$2.02 \mathrm{E}-01$
6. $45 \mathrm{E}-12$
$1.35 \mathrm{E}-11$
$2.97 \mathrm{E}-61$

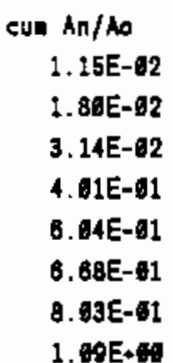

0 inc.

$\mathrm{ct} 2 / \mathrm{sec}$

D eua en2/sec

6.68 1.15E-62

4. $58 \mathrm{E}-69$

$4.58 \mathrm{E}-69$

6.29 B.49E-63

$1.92 \mathrm{E}-99$

$3.20 \mathrm{E}-69$

$1.06 \quad 1.34 \mathrm{E}-62$

2. 48E-99

2.82E-69

.66

2. $27 \mathrm{E}-86$

2.39E-07

3. $48 E-97$

4.69

$1.16 E-86$

3. $18 \mathrm{E}-97$

46. 69

1.65E-87

B. BAE- $9 B$

$7.37 E-98$

TABLE B.6-6. Am-241 Fraction Leached for ANS 16.1 Leach Test: Whole Grout In Hanford Ground Water (106AN 4-1)

$\begin{array}{lc} & \text { SAMPLE ID } \\ \text { JBBAN } & 4-1 \\ 1 \text { 16BAN } & 4-2 \\ 1 \text { 168AN } & 4-3 \\ 1 \text { 198AN } & 4-4 \\ 196 A N & 4-6 \\ 198 A N & 4-6 \\ 166 A N & 4-7 \\ 196 A N & 4-8\end{array}$

\begin{tabular}{|c|c|}
\hline TOT. LEACH $\left(\boldsymbol{N}_{n}\right)$ & CUI. LEACH \\
\hline $0.71 E-88$ & $6.71 \mathrm{E}-18$ \\
\hline $3.55 \mathrm{E}-86$ & 1. 03E- $\$ 5$ \\
\hline $3.47 \mathrm{E}-0.5$ & $4.56 E-86$ \\
\hline 4.13E-86 & 4.91E-95 \\
\hline $1.22 E-68$ & $5.03 E-65$ \\
\hline 2. $67 \mathrm{E}-66$ & 5. 39E-A5 \\
\hline 1. $09 \mathrm{E}-65$ & 6. 40E-85 \\
\hline $1.07 \mathrm{E}-05$ & $7.46 \mathrm{E}-85$ \\
\hline
\end{tabular}

TINE OAYS
0.06
0.29
1.68
2.09
3.80
4.00
19.06
48.06

$A n / 40$
$5.28 E-94$
$2.79 E-94$
$2.74 E-93$
$3.25 E-94$
$9.57 E-95$
$2.11 E-94$
6. $81 E-94$
B. $42 E-94$

Cun An/ho
$5.28 \mathrm{E}-64$
8. $67 \mathrm{E}-64$
$3.54 \mathrm{E}-83$
$3.87 \mathrm{E}-63$
$3.98 \mathrm{E}-89$
$4.19 \mathrm{E}-63$
$5.04 \mathrm{E}-93$
$5.88 \mathrm{E}-83$

D i

enc. $2 /$ sec
3.58E-12
$1.55 \mathrm{E}-12$
$1.60 \mathrm{E}-19$
$1.78 \mathrm{E}-12$
$2.58 \mathrm{E}-13$
$1.78 \mathrm{E}-12$
$3.86 \mathrm{E}-13$
3. $44 \mathrm{E}-13$

D cum ear/sec

9. $58 \mathrm{E}-12$

6. $41 \mathrm{E}-12$

3. $58 \mathrm{E}-11$

2.13E-12

1. 49E-11

1.24E-11

3. $81 \mathrm{E}-12$

2. 14E-12 
.

.

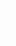


APPENDIX C

MASS BALANCE CALCULATIONS 
TABLE C.1. Mass Balance Calculations for Aluminum (AT)

STATIC LEACH TEST

\begin{tabular}{|c|c|c|c|c|}
\hline SALPLE NQ. & $\begin{array}{c}\text { EFLUENT } \\
\text { ppin Al }\end{array}$ & $\begin{array}{c}\text { HoW CoNC. } \\
\text { ppD Al }\end{array}$ & $\begin{array}{l}\text { EUTE } \\
\text { a } A \text { | }\end{array}$ & $\begin{array}{c}\text { TOTAL CHANGE } \\
\text { og A! }\end{array}$ \\
\hline $51-1$ & 0.84 & 6.84 & -4.38 & -6.36 \\
\hline $51-2$ & 5.31 & 0.4 & 3.12 & 2.77 \\
\hline $51-3$ & B. 25 & 9.64 & 2.00 & 4.77 \\
\hline $51-4$ & 11.20 & 0.84 & 2.15 & 6.92 \\
\hline
\end{tabular}

\begin{tabular}{|c|c|c|c|c|}
\hline SNIPLE NO. & $\begin{array}{l}\text { EFLUET } \\
\text { PPa AI }\end{array}$ & $\begin{array}{c}\text { HG CDMC. } \\
\text { ppI Al }\end{array}$ & $\begin{array}{l}\text { EUTED } \\
\operatorname{lng} \text { Al }\end{array}$ & $\begin{array}{c}\text { TOTNL CHANCE } \\
\text { og Al }\end{array}$ \\
\hline $52-1$ & 2.40 & 0.84 & 1.66 & 1.86 \\
\hline S2-2 & 6.40 & 0.24 & 2.49 & 3.54 \\
\hline S2-3 & 11.36 & 0.24 & 3.23 & 8.77 \\
\hline $52-4$ & 14.20 & 0.64 & 2.27 & 9.04 \\
\hline
\end{tabular}

ANS 16.1 LECH TEST

\begin{tabular}{|c|c|c|c|c|}
\hline SAPPLE NO. & $\begin{array}{c}\text { EFLLENT } \\
\text { PP AI }\end{array}$ & $\begin{array}{l}\text { HOI casc. } \\
\text { ppo Al }\end{array}$ & $\begin{array}{l}\text { EUTED } \\
\text { E } A 1\end{array}$ & $\begin{array}{l}\text { SLU EUTED } \\
\text { Al }\end{array}$ \\
\hline A3-1 & 0.35 & 0.84 & -6.17 & -0.17 \\
\hline$A 3-2$ & 0.21 & 0.64 & -0.26 & -8.43 \\
\hline $13-3$ & .24 & 1.64 & -9.24 & -6.88 \\
\hline $13-4$ & 0.16 & 0.4 & -8.29 & -9.98 \\
\hline A3-6 & 0.10 & 1. 64 & -6.32 & -1.29 \\
\hline$A 3-B$ & 0.10 & 0.64 & -0.33 & -1.81 \\
\hline A3-7 & 1.33 & 0.84 & 0.41 & -1.26 \\
\hline A3-8 & 0.97 & 6.64 & 0.29 & -1.60 \\
\hline A3-9 & .20 & 0.84 & -0.26 & -1.27 \\
\hline
\end{tabular}

SAILE NO. EFLUENT HGI CONC. ELUTE SLI ELUTED

\begin{tabular}{|c|c|c|c|c|}
\hline $14-1$ & $\$ .37$ & 0.84 & -6.18 & -0.18 \\
\hline A4-2 & 6.15 & 6.84 & -0.29 & -8.48 \\
\hline$A 4-3$ & 0.17 & 0.64 & -0.29 & -0.74 \\
\hline 14-4 & 0.26 & 6.84 & -8.28 & -1.06 \\
\hline A4-6 & a. 16 & 0.84 & -8.29 & -1.29 \\
\hline A4-8 & 0.09 & 0.64 & -9.33 & -1.62 \\
\hline $14-7$ & 2.29 & 6.84 & 0.99 & -8.83 \\
\hline$A 4-8$ & 1.48 & 6.84 & 0.59 & -0.13 \\
\hline A4-9 & 6.21 & 0.64 & -0.28 & -8.39 \\
\hline
\end{tabular}

C. 1 
TABLE C.2. Mass Balance Calculations for Boron (B) STATIC LEACH TEST

\begin{tabular}{|c|c|c|c|c|}
\hline SAIPLE NU. & $\begin{array}{l}\text { EFLUENT } \\
\text { Pp: B }\end{array}$ & $\begin{array}{c}\text { Hor CONC. } \\
\text { ppa } \mathrm{B}\end{array}$ & 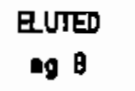 & $\begin{array}{c}\text { TOTAL CHAKCE } \\
\text { og } \mathrm{B}\end{array}$ \\
\hline $51-1$ & 5.17 & I. 61 & 2.86 & 2.80 \\
\hline s1-2 & 10.80 & 0.51 & 3.55 & 8.34 \\
\hline $51-3$ & 13.70 & 1. 51 & 2.31 & 8.65 \\
\hline $51-4$ & 16.70 & 51 & 2.48 & 11.11 \\
\hline
\end{tabular}

\begin{tabular}{|c|c|c|c|c|}
\hline SAIPLE RO. & $\begin{array}{c}\text { EFLUET } \\
\text { Pp } 1\end{array}$ & $\begin{array}{c}\text { HOT CONC. } \\
\text { Ppe } B\end{array}$ & $\begin{array}{c}\text { EUTED } \\
\text { og } \mathrm{B}\end{array}$ & $\begin{array}{c}\text { TOTAL CHANCE } \\
\text { on } \mathrm{B}\end{array}$ \\
\hline 52-1 & 7.21 & 0.51 & 4.12 & 4.82 \\
\hline S2-2 & 9.84 & 0.51 & 1.91 & 5.93 \\
\hline $52-3$ & 14.81 & 0.51 & 2.97 & 8.90 \\
\hline $52-4$ & 18.81 & t.51 & 3. 00 & 11.98 \\
\hline
\end{tabular}

NSS 16.1 LEACH TEST

\begin{tabular}{|c|c|c|c|c|}
\hline SAUPLE NO. & $\begin{array}{l}\text { EFLLEXT } \\
\text { ppa B }\end{array}$ & $\begin{array}{l}\text { Hot colc. } \\
\text { ppm 日 }\end{array}$ & $\begin{array}{c}\text { EUTED } \\
\text { Ig } \mathrm{B}\end{array}$ & $\begin{array}{c}\text { SW EUTED } \\
\text { ng B }\end{array}$ \\
\hline$A^{3}-1$ & 2.62 & I. 51 & 0.91 & 8. 91 \\
\hline $13-2$ & 1.42 & 6.51 & 0.55 & 1.48 \\
\hline A3-3 & 1.77 & t. 51 & 6.70 & 2.22 \\
\hline$A^{3}-4$ & 1.82 & I. 51 & 0.79 & 3.00 \\
\hline A3-5 & 1.42 & 0.51 & 0. 55 & 3.55 \\
\hline A3-6 & 1.10 & 6.51 & 1.36 & 3.90 \\
\hline $13-7$ & 5.28 & 0.51 & 2.85 & 6.70 \\
\hline$A 3-8$ & 3.28 & U. 61 & 1.85 & B. 41 \\
\hline A3-O & 2.72 & t. 51 & 1.33 & 9.73 \\
\hline
\end{tabular}

\begin{tabular}{|c|c|c|c|c|}
\hline SAUPPE KO. & $\begin{array}{l}\text { EFLLEIT } \\
\text { PPI B }\end{array}$ & $\begin{array}{c}\text { HGT COMC. } \\
\text { Ppm B }\end{array}$ & $\begin{array}{c}\text { RUTED } \\
\text { ag } \mathrm{B}\end{array}$ & $\begin{array}{c}\text { SW EUTED } \\
\text { ng } \theta\end{array}$ \\
\hline A4-1 & 2.05 & 0.51 & 0.93 & 0.93 \\
\hline $14-2$ & 1.18 & 0.51 & 0.39 & 1.32 \\
\hline $14-3$ & 1.49 & 0.51 & 1. 50 & 1.80 \\
\hline A4-4 & 2.01 & 6. 51 & .90 & 2.81 \\
\hline A4-5 & 1.45 & 6.51 & 1.58 & 3.37 \\
\hline A4-8 & 1.32 & 9.51 & 0.48 & 3.95 \\
\hline A4-7 & 6.68 & 6. 51 & 3.71 & 7.56 \\
\hline 14-8 & 4.17 & G. 51 & 2.20 & 9.78 \\
\hline $14-9$ & 2.97 & - .51 & 1.41 & 11.17 \\
\hline
\end{tabular}


TABLE C.3. Mass Balance Calculations for Calcium (Ca)

STATIC LEACH TEST

\begin{tabular}{|c|c|c|c|c|}
\hline SAMPE NO. & $\begin{array}{l}\text { EFLlENT } \\
\text { ppa Ca }\end{array}$ & $\begin{array}{l}\text { HOW cOKC. } \\
\text { ppm Ca }\end{array}$ & $\begin{array}{l}\text { BUTED } \\
\text { ag Ca }\end{array}$ & $\begin{array}{c}\text { TOTAL CHANGE } \\
\text { mg Ca }\end{array}$ \\
\hline S1-1 & 3.61 & 58.89 & -33.11 & -33.11 \\
\hline $51-2$ & 2.25 & 58.69 & -3.58 & -38.89 \\
\hline S1-3 & 3.57 & 58.80 & -2.04 & -38.73 \\
\hline $51-4$ & 4.88 & 58.80 & -1.97 & -40.70 \\
\hline
\end{tabular}

\begin{tabular}{|c|c|c|c|c|}
\hline SAUPLE NO. & $\begin{array}{l}\text { EFLUET } \\
\text { ppu Ca }\end{array}$ & $\begin{array}{l}\text { HAT CONC. } \\
\text { ppm Ca }\end{array}$ & $\begin{array}{l}\text { EUTED } \\
\text { mg Ca }\end{array}$ & $\begin{array}{c}\text { TOTAL CHANGE } \\
\text { ig Ca }\end{array}$ \\
\hline $52-1$ & 2.89 & 58.80 & -34.63 & -34.93 \\
\hline S2-2 & 2.26 & 58.89 & -2.73 & -38.76 \\
\hline S2-3 & 6.90 & 58.81 & -9.59 & -37.35 \\
\hline $52-4$ & 8.35 & 58.88 & -1.22 & -38.57 \\
\hline
\end{tabular}

ANS 16.1 LEACH TEST

\begin{tabular}{|c|c|c|c|c|}
\hline SAUPLE NO. & $\begin{array}{c}\text { ERLUET } \\
\text { ppa 6a }\end{array}$ & $\begin{array}{l}\text { HG CONC. } \\
\text { ppa Ca }\end{array}$ & $\begin{array}{l}\text { 日UTED } \\
\text { ng Ca }\end{array}$ & $\begin{array}{c}\text { SU EUTED } \\
\text { ig } \mathrm{Ca}\end{array}$ \\
\hline$A^{3}-1$ & 20.10 & 58.80 & -17.82 & $-\$ 7.82$ \\
\hline$A 3-2$ & 30.58 & 58.80 & -16.98 & -34.88 \\
\hline A3-3 & 25.20 & 58.80 & -28.18 & -54.98 \\
\hline 13-4 & 19.80 & 58.80 & -23.52 & -78.48 \\
\hline A3-5 & 23.40 & 58.80 & -21.24 & -99.72 \\
\hline A3-8 & 25.60 & 58.89 & -19.92 & -118.64 \\
\hline A3-7 & 1.90 & 58.80 & -34.10 & -153.74 \\
\hline A3-8 & 2.67 & 68.80 & -33.68 & -187.42 \\
\hline A3-8 & 2.91 & 68.80 & -33.53 & -225.96 \\
\hline
\end{tabular}

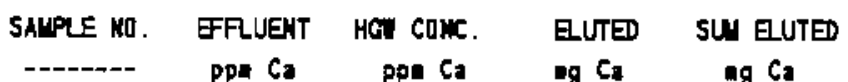

\begin{tabular}{|c|c|c|c|c|}
\hline 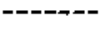 & $\mathrm{pp}$ Ca & pon Ca & $\lg \mathrm{Ca}$ & $\operatorname{mg} \mathrm{Ca}$ \\
\hline $14-1$ & 25.99 & 58.89 & -19.74 & -19.74 \\
\hline A4-2 & 31.79 & 58.89 & -18.28 & -38.80 \\
\hline$A 4-3$ & 28.28 & 58.89 & -18.36 & -54.36 \\
\hline $14-4$ & 18.80 & 58.89 & -25.32 & -79.88 \\
\hline $14-5$ & 27.31 & 58.89 & -18.90 & -96.58 \\
\hline A4-6 & 21.70 & 58.86 & -22.26 & -120.84 \\
\hline A4-7 & 2.63 & 58.80 & -33.79 & -154.54 \\
\hline A4-8 & 2.81 & 58.89 & -33.71 & -188.28 \\
\hline 14-9 & 2.55 & 58.80 & -33.78 & -222.01 \\
\hline
\end{tabular}


TABLE C.4. Mass Balance Calculations for Potassium (K) STATIC LEACH TEST

\begin{tabular}{|c|c|c|c|c|}
\hline SALPLE NO. & $\begin{array}{l}\text { EFLLENT } \\
\text { Ppa K }\end{array}$ & $\begin{array}{l}\text { HG CONC. } \\
\text { Pp: } x\end{array}$ & $\begin{array}{l}\text { EUTED } \\
\text { wg } K\end{array}$ & $\begin{array}{c}\text { TOTAL CHANCE } \\
\text { ag } k\end{array}$ \\
\hline $51-1$ & 17.90 & 7.37 & 6.32 & 6.32 \\
\hline$\$ 1-2$ & 28.00 & 7.37 & 6.50 & 12.90 \\
\hline $51-3$ & 32,45 & 7.37 & 3.76 & 16.81 \\
\hline $51-4$ & 38.90 & 7.37 & 3.92 & 20.53 \\
\hline
\end{tabular}

\begin{tabular}{|c|c|c|c|c|}
\hline SALPLE NO. & $\begin{array}{l}\text { GFLUET } \\
\text { Ppa } K\end{array}$ & $\begin{array}{l}\text { HAT CONC. } \\
\text { ppe } K\end{array}$ & $\begin{array}{l}\text { EUTED } \\
\text { ng } k\end{array}$ & $\begin{array}{c}\text { TOTAL CHANCE } \\
\text { ag } k\end{array}$ \\
\hline \$2-1 & 18.20 & 7.37 & 7.10 & 7.10 \\
\hline $52-2$ & 20.00 & 7.37 & 4.67 & 11.77 \\
\hline $52-3$ & 31.80 & 7.37 & 4.29 & 18.96 \\
\hline $52-4$ & 37.20 & 7.37 & 4.67 & 26.83 \\
\hline
\end{tabular}

NS 16.1 IENCH TEST

\begin{tabular}{|c|c|c|c|c|}
\hline SAPPLE NO. & $\begin{array}{l}\text { EFLUET } \\
\text { ppe } K\end{array}$ & $\begin{array}{l}\text { HOS CDNC. } \\
\text { opn } K\end{array}$ & $\begin{array}{l}\text { EUTED } \\
\text {-g } x\end{array}$ & $\begin{array}{c}\text { SU EUTED } \\
\lg k\end{array}$ \\
\hline A3-1 & 10.40 & 7.37 & 1.82 & 1.82 \\
\hline A3-2 & 8.86 & 7.37 & 6.86 & 2.68 \\
\hline A3-3 & 10.00 & 7.37 & 1.58 & 4.25 \\
\hline AS-4 & 0.80 & 7.37 & 1.48 & 5.71 \\
\hline AS-5 & 9.10 & 7.37 & 1.04 & 0.75 \\
\hline A3-6 & B.90 & 7.37 & 1.82 & 7.87 \\
\hline A3-7 & 18.01 & 7.37 & 6.18 & 12.85 \\
\hline AS-8 & 12.64 & 7.37 & 2.78 & 15.62 \\
\hline AS-O & 11.80 & 7.37 & 2.66 & 18.28 \\
\hline
\end{tabular}

\begin{tabular}{|c|c|c|c|c|}
\hline SALPRLE NO. & $\begin{array}{l}\text { EFLUENT } \\
\text { PPE X }\end{array}$ & $\begin{array}{l}\text { HOW CONC. } \\
\text { ppa K }\end{array}$ & $\begin{array}{l}\text { EUTED } \\
\text {-g } K\end{array}$ & $\begin{array}{l}\text { SUY } \text { 日UTED } \\
\text { g } k\end{array}$ \\
\hline M-1 & 16.89 & 7.37 & 2.96 & 2.86 \\
\hline A4-2 & 8.71 & 7.37 & 4.86 & 2.86 \\
\hline$A 4-3$ & 9.3 & 7.37 & 1.18 & 4.01 \\
\hline A4-4 & 9.70 & 7.37 & 1.40 & 5.41 \\
\hline A4-5 & 6.90 & 7.37 & 0.92 & 6.33 \\
\hline A4-6 & 9.10 & 7.37 & 1.04 & 7.37 \\
\hline A4-7 & 17.60 & 7.37 & 6.14 & 13.51 \\
\hline$A 4-8$ & 13.80 & 7.37 & 3.80 & 17.38 \\
\hline A4-9 & 12.26 & 7.37 & 2.96 & 20.26 \\
\hline
\end{tabular}

C. 4 
TABLE C.5. Mass Balance Calculations for Magnesium (Mg)

STATIC LEACH TEST

\begin{tabular}{|c|c|c|c|c|}
\hline SAUDEE NO. & $\begin{array}{c}\text { EFLUENT } \\
\text { Ppe b }\end{array}$ & 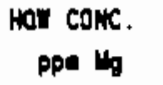 & $\begin{array}{l}\text { BUTED } \\
\text { g ט }\end{array}$ & $\begin{array}{c}\text { TOTAL CHANCE } \\
\text { og bo }\end{array}$ \\
\hline S1-1 & 0.88 & 14.60 & -8.36 & -8.36 \\
\hline$\$ 1-2$ & 1.68 & 14.09 & -9.70 & -9.68 \\
\hline $51-3$ & 1.66 & 14.60 & $-0.7 \theta$ & -9.76 \\
\hline $51-4$ & 0.06 & 14. 89 & -0.70 & -10.48 \\
\hline SALEE NO. & $\begin{array}{c}\text { EFLLET } \\
\text { ppa U }\end{array}$ & $\begin{array}{c}\text { HOT CONC. } \\
\text { ppa bu bu }\end{array}$ & 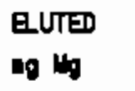 & 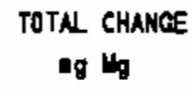 \\
\hline $52-1$ & 1.08 & 14.60 & -8.38 & -8.36 \\
\hline \$2-2 & 6.68 & 14.09 & -9.70 & -9.06 \\
\hline $52-3$ & 0.08 & 14.09 & -8.70 & -9.76 \\
\hline S2-4 & 0.68 & 14.90 & -0.70 & -19.46 \\
\hline
\end{tabular}

NS 18.1 LEACH TEST

\begin{tabular}{|c|c|c|c|c|}
\hline SAOLE NO. & $\begin{array}{c}\text { EFLLET } \\
\text { ppe }\end{array}$ & $\begin{array}{c}\text { HOT CONC. } \\
\text { ppa bu }\end{array}$ & 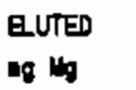 & 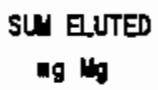 \\
\hline $\mathrm{AB}^{3}-1$ & 11.70 & 14.60 & -1.38 & -1.38 \\
\hline$A 3-2$ & 11.28 & 14.00 & -1.88 & -3.68 \\
\hline A3-3 & 9.17 & 14.64 & -2.90 & -5.98 \\
\hline A3-4 & 8.12 & 14.00 & -3.63 & -9.49 \\
\hline A3-5 & 8.81 & 14.80 & -3.11 & -12.60 \\
\hline A3-8 & 9.87 & 14.09 & -2.48 & -16.68 \\
\hline A3-7 & 0.68 & 14.60 & -8.36 & -23.44 \\
\hline A3-8 & 1. 28 & 140 & -8.24 & -31.69 \\
\hline A3-9 & 0.91 & 14.60 & -7.85 & -39.54 \\
\hline
\end{tabular}

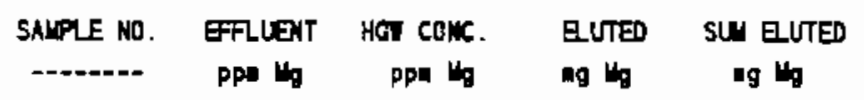

$\begin{array}{lllll}A 4-1 & 11.40 & 14.60 & -1.58 & -1.58 \\ A 4-2 & 11.46 & 14.00 & -1.58 & -3.12 \\ A 4-3 & 9.41 & 14.00 & -2.75 & -5.87 \\ A 4-4 & 7.73 & 14.00 & -3.78 & -9.64 \\ A 4-6 & 9.27 & 14.60 & -2.84 & -12.47 \\ A 4-8 & 9.17 & 14.60 & -2.98 & -15.37 \\ A 4-7 & 0.08 & 14.60 & -8.38 & -23.74 \\ A 4-8 & 0.17 & 14.00 & -8.38 & -32.63 \\ A 4-9 & 0.68 & 14.96 & -7.99 & -40.82\end{array}$

$$
\text { C. } 5
$$


IABLE C.6. Mass Balance Calculations for Molybdenum (Mo) STATIC LEACH TEST

\begin{tabular}{|c|c|c|c|c|}
\hline SAMPLE NO. & $\begin{array}{l}\text { EFLUET } \\
\text { ppa bo }\end{array}$ & $\begin{array}{c}\text { HGT CaNC. } \\
\text { ppa b to }\end{array}$ & $\begin{array}{l}\text { EUTED } \\
\text { ing b }\end{array}$ & $\begin{array}{c}\text { TOTAL CHANCE } \\
\text { ug b }\end{array}$ \\
\hline$\$ 1-1$ & 0.14 & 0.01 & 0.98 & 6.68 \\
\hline$\$ 1-2$ & .31 & 9.01 & 0.11 & 0.19 \\
\hline$\$ 1-3$ & 142 & 0.01 & 0.08 & .20 \\
\hline$\$ 1-4$ & 0.52 & D. 01 & 0.08 & 6.35 \\
\hline
\end{tabular}

\begin{tabular}{|c|c|c|c|c|}
\hline SAYPLE NO. & 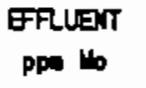 & $\begin{array}{l}\text { HG colic. } \\
\text { ppe to }\end{array}$ & $\begin{array}{l}\text { EUाED } \\
\text { og b }\end{array}$ & $\begin{array}{c}\text { TOTAL CHANEE } \\
\text { •g }\end{array}$ \\
\hline \$2-1 & 1.21 & 1.01 & 0.12 & 12 \\
\hline \$2-2 & 0.27 & 0.01 & 0.05 & 0.17 \\
\hline \$2-3 & 1.30 & 0.01 & 0.88 & 0.25 \\
\hline$\$ 2-4$ & 0.62 & 1.01 & 6.69 & 0.35 \\
\hline
\end{tabular}

AHS 16.1 LEACH TEST

\begin{tabular}{|c|c|c|c|c|}
\hline SAIPLE NO. & $\begin{array}{c}\text { ERLGert } \\
\text { Ppa b }\end{array}$ & $\begin{array}{l}\text { HOS CONC. } \\
\text { ppa to to }\end{array}$ & $\begin{array}{l}\text { E.णाE } \\
\text { סט פם }\end{array}$ & 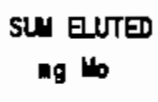 \\
\hline A3-1 & $\bullet .01$ & c.01 & 0.00 & 0.56 \\
\hline AS-2 & 0.01 & I. 11 & 0.00 & 0.90 \\
\hline As-3 & 0.91 & 0.01 & 0.09 & 0.00 \\
\hline 13-4 & 6.1 & 0.01 & 0.80 & 0.00 \\
\hline A3-6 & ๑. 1 & 0.1 & 5.66 & 0.00 \\
\hline A3-8 & c.t.1 & 0.01 & 9.60 & 6.00 \\
\hline A3-7 & 0.18 & 0.01 & 4.89 & 0.69 \\
\hline$A 3-B$ & 0.01 & 0.01 & 0.60 & 1.60 \\
\hline A3-9 & 0.60 & 6.01 & 0.95 & 0.1 \\
\hline
\end{tabular}

SAIPLE NO. GFLUET HGI CONC. BUTED SLI EUTED

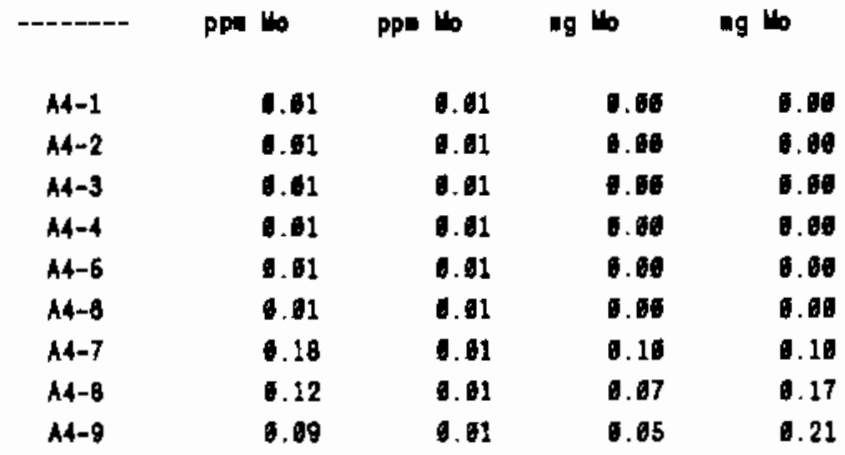

C. 6 
TABLE C.7. Mass Balance Calculations for Sodium (Na)

STATIC LEACH TEST

\begin{tabular}{|c|c|c|c|c|}
\hline SAIPLE NO. & $\begin{array}{l}\text { GfLUET } \\
\text { ppa Ha }\end{array}$ & $\begin{array}{l}\text { Hot cale. } \\
\text { pon ha }\end{array}$ & $\begin{array}{l}\text { EUTED } \\
\text { a } \mathrm{ka}\end{array}$ & $\begin{array}{c}\text { TOTAL CHAMGE } \\
\square \mathrm{Ma}\end{array}$ \\
\hline \$1-1 & 423.01 & 24.80 & 236.92 & 239.92 \\
\hline$S 1-2$ & 884.10 & 24.80 & 294.11 & 539.63 \\
\hline $51-3$ & 1071. & 24.80 & 157.38 & 699.39 \\
\hline $51-4$ & 1282.00 & 24.80 & 168.91 & 857.39 \\
\hline
\end{tabular}

\begin{tabular}{|c|c|c|c|c|}
\hline SALPLE NO. & $\begin{array}{l}\text { EFLUENT } \\
\text { ppa Na }\end{array}$ & $\begin{array}{l}\text { HGT COMC. } \\
\text { PPE tha }\end{array}$ & $\begin{array}{l}\text { EUTED } \\
\text { ng } \mathrm{Na}\end{array}$ & $\begin{array}{c}\text { TOTN CHANGE } \\
\text { Na }\end{array}$ \\
\hline \$2-1 & 540.01 & 24.80 & 313.92 & 313.92 \\
\hline$\$ 2-2$ & B10.00 & 24.89 & 183.36 & $497.2 B$ \\
\hline $52-3$ & 1140.00 & 24.80 & 237.26 & 734.54 \\
\hline $52-4$ & 1285 . & 24.80 & 142.76 & 877.30 \\
\hline
\end{tabular}

NS 16.1 LEACH TEST

\begin{tabular}{|c|c|c|c|c|}
\hline SAIPLE NO. & $\begin{array}{l}\text { GfLUET } \\
\text {. ppn } \mathrm{Ha}\end{array}$ & $\begin{array}{l}\text { Hor cone. } \\
\text { ppa Ha }\end{array}$ & $\begin{array}{l}\text { EUTED } \\
\text { • } \mathrm{Na}\end{array}$ & $\begin{array}{l}\text { SU EUTED } \\
\text { ه } \mathrm{kt}\end{array}$ \\
\hline A3-1 & 143.66 & 24.89 & 70.92 & 76.92 \\
\hline A3-2 & 87.80 & 24.80 & 37.68 & 108.80 \\
\hline A3-3 & 142.01 & 24.80 & 70.32 & 178.92 \\
\hline A3-4 & 140.00 & 24.80 & 60.12 & 240.04 \\
\hline A3-5 & 100.00 & 24.84 & 50. 52 & 298.58 \\
\hline$A^{3}-6$ & 89.10 & 24.80 & 38.58 & 397.14 \\
\hline A3-7 & 420.91 & 24.80 & 240.72 & 577.86 \\
\hline A3-8 & 201.00 & 24.84 & 150.72 & 737.58 \\
\hline $13-9$ & 231.06 & 24.89 & 123.72 & 861.36 \\
\hline
\end{tabular}

SALPLE NO. EFLUENT HGT COM. GUTED SLI ELUTED

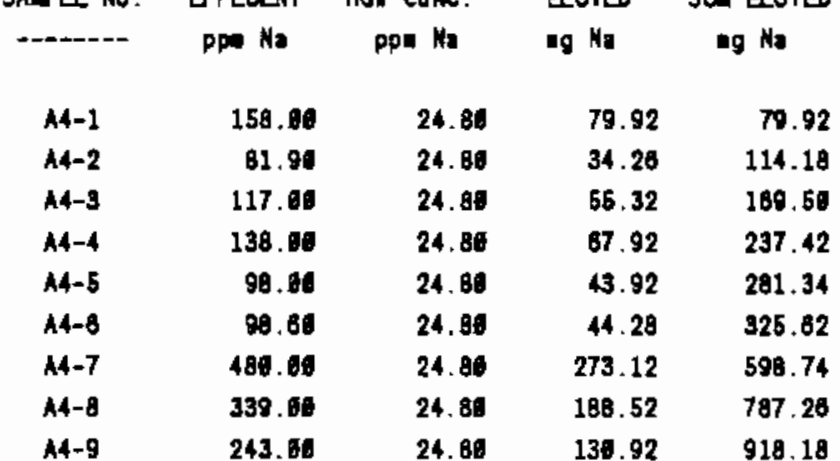

C.7 
IABLE C.8. Mass Balance Calculations for Fluorine (F) STATIC LEACH TEST

\begin{tabular}{|c|c|c|c|c|}
\hline SAVPLE NO. & $\begin{array}{l}\text { EFluent } \\
\text { ppe } F\end{array}$ & $\begin{array}{c}\text { HaT CONC. } \\
\text { Ppu } F\end{array}$ & $\begin{array}{l}\text { EUTED } \\
\text { ig } F\end{array}$ & $\begin{array}{c}\text { TOTAL CHANCE } \\
\text { } F\end{array}$ \\
\hline S1-1 & 0.78 & 0.57 & 0.12 & 1.12 \\
\hline s1-2 & 1.18 & . .57 & 0.25 & 1.38 \\
\hline $51-3$ & 1.22 & 1. 57 & 0.85 & 0.43 \\
\hline $51-4$ & 1.26 & 6. 57 & 0.00 & 0.49 \\
\hline
\end{tabular}

\begin{tabular}{|c|c|c|c|c|}
\hline SAUPLE NO. & $\begin{array}{l}\text { EFLUenT } \\
\text { ppe F }\end{array}$ & $\begin{array}{l}\text { HaT CONC. } \\
\text { PPE F }\end{array}$ & $\begin{array}{l}\text { EUासD } \\
\text { ig } F\end{array}$ & $\begin{array}{c}\text { TOTAL CHANCE } \\
\sim F\end{array}$ \\
\hline 52-1 & C.89 & 0. 57 & 0.10 & 0.19 \\
\hline $52-2$ & 1.17 & t. 57 & c.18 & 9. .37 \\
\hline $52-3$ & 1.23 & .57 & 0.07 & 0.44 \\
\hline $52-4$ & 1.34 & .57 & 0.10 & 0.54 \\
\hline
\end{tabular}

NS 10.1 LEACH TEST

\begin{tabular}{|c|c|c|c|c|}
\hline SAUPLE ND. & $\begin{array}{c}\text { EFUET } \\
\text { pp F }\end{array}$ & $\begin{array}{l}\text { HaI CONC. } \\
\text { gpa } F\end{array}$ & $\begin{array}{l}\text { BUIED } \\
\text { g } \mathbf{F}\end{array}$ & $\begin{array}{c}\text { SUN EUTED } \\
\qquad F\end{array}$ \\
\hline A3-1 & 1.87 & 0.57 & ข. 86 & 1.06 \\
\hline A3-2 & 6.03 & I. 67 & 1.03 & 0.00 \\
\hline A3-3 & 1.88 & 0.57 & 5. 06 & 9.18 \\
\hline $13-4$ & 6.72 & .67 & 0.09 & 0.25 \\
\hline A3-5 & 6.70 & 0.57 & 6. 68 & 0.32 \\
\hline A3-6 & 6.85 & 1.67 & 0.45 & 0.37 \\
\hline A3-7 & 6.93 & 1. 57 & 0.21 & 1. 69 \\
\hline A3-B & 6.74 & 0.67 & 0.10 & 0.69 \\
\hline $13-9$ & 6.80 & 0.67 & 6.12 & 0.70 \\
\hline SAUPLE MQ. & $\begin{array}{c}\text { EFlext } \\
\text { ppa F }\end{array}$ & $\begin{array}{c}\text { HoT caNe. } \\
\text { ppe F }\end{array}$ & $\begin{array}{c}\text { EUTED } \\
\bullet 9 F\end{array}$ & $\begin{array}{l}\text { SUI EUTED } \\
\text { \& } F\end{array}$ \\
\hline A4-1 & 1.80 & 1.57 & 0.66 & 0.00 \\
\hline A4-2 & 1.68 & .57 & 0.05 & 0.12 \\
\hline $14-3$ & 9.64 & 6.57 & 1.94 & 0.16 \\
\hline 14-4 & 0.85 & 6.57 & 0.05 & 0.21 \\
\hline A4-5 & 0.68 & t. 57 & a.68 & o. 27 \\
\hline A4-8 & 0.84 & 0.57 & 0.04 & 0.31 \\
\hline A4-7 & 1.05 & 0.57 & .29 & 0.60 \\
\hline$A 4-8$ & 0.81 & .57 & 14 & 0.74 \\
\hline $14-9$ & .80 & ด. 57 & B.65 & 0.78 \\
\hline
\end{tabular}

C. 8 
TABLE C.9. Mass Balance Calculations for Chloride (C1)

STATIC LENCH TEST

\begin{tabular}{|c|c|c|c|c|}
\hline SALPLE ND. & $\begin{array}{l}\text { EFLUETT } \\
\text { PpA CI }\end{array}$ & $\begin{array}{l}\text { HOT CONC. } \\
\text { ppm CI }\end{array}$ & $\begin{array}{l}\text { BUTED } \\
\text { ag Cl }\end{array}$ & $\begin{array}{c}\text { TOTAL CHANCE } \\
\text { ag CI }\end{array}$ \\
\hline $51-1$ & 28.26 & 22.50 & 3.42 & 3.42 \\
\hline $51-2$ & 44.65 & 22.50 & 9.76 & 13.18 \\
\hline S1-3 & 51.00 & 22.50 & 5.27 & 18.46 \\
\hline $51-4$ & 59.00 & 22.58 & 5.62 & 24.88 \\
\hline
\end{tabular}

\begin{tabular}{|c|c|c|c|c|}
\hline SAIPLE NO. & $\begin{array}{l}\text { EFLUET } \\
\text { ppa CI }\end{array}$ & $\begin{array}{l}\text { Het conc. } \\
\text { ppa C1 }\end{array}$ & $\begin{array}{l}\text { EUTED } \\
\text { n CI }\end{array}$ & $\begin{array}{c}\text { TOTAL CHANGE } \\
\text { ag Cl }\end{array}$ \\
\hline $52-1$ & 29.80 & 22.50 & 4.28 & 4.28 \\
\hline S2-2 & 42.56 & 22.50 & B. 09 & 12.35 \\
\hline $52-3$ & 49.96 & 22.60 & 5.44 & 17.79 \\
\hline $52-4$ & 57.64 & 22.50 & 5.63 & 23.42 \\
\hline
\end{tabular}

ANS 16.1 LEACH TEST

\begin{tabular}{|c|c|c|c|c|}
\hline SAHEE NO. & $\begin{array}{l}\text { ErLUET } \\
\text { ppa CI }\end{array}$ & $\begin{array}{l}\text { Hot cone. } \\
\text { ppu Cl }\end{array}$ & $\begin{array}{l}\text { 日UTED } \\
\text { g C1 }\end{array}$ & $\begin{array}{c}\text { SU BUTED } \\
\text { ag } \mathrm{Cl}\end{array}$ \\
\hline A3-1 & 28.20 & 22.50 & 2.22 & 2.22 \\
\hline A3-2 & 24.86 & 22.50 & 1.38 & 3.60 \\
\hline A3-3 & 26.40 & 22.50 & 2.34 & 5.94 \\
\hline A3-4 & 28.46 & 22.50 & 2.34 & B. 28 \\
\hline A3-5 & 26.86 & 22.50 & 2.48 & 10.74 \\
\hline A3-6 & 26.46 & 22.59 & 2.10 & 12.84 \\
\hline$A 3-7$ & 34.56 & 22.50 & 7.20 & 26.64 \\
\hline$A 3-8$ & 28.91 & 22.50 & 3.84 & 23.88 \\
\hline$A 3-9$ & 27.00 & 22.58 & $2.7 \theta$ & 26.58 \\
\hline
\end{tabular}

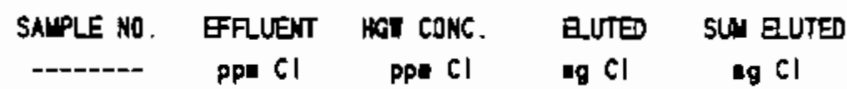

\begin{tabular}{|c|c|c|c|c|}
\hline A4-1 & 26.26 & 22.51 & 2.22 & 2.22 \\
\hline A4-2 & 25.46 & 22.59 & 1.74 & 3.96 \\
\hline A4-3 & 27.01 & 22.50 & 3.06 & 7.62 \\
\hline A4-4 & 28.00 & 22.50 & 2.16 & 9.12 \\
\hline A4-6 & 26.40 & 22.50 & 2.34 & 11.46 \\
\hline A4-6 & 25.86 & 22.50 & 1.98 & 13.44 \\
\hline A4-7 & 37.56 & 22.50 & 9.66 & 22.44 \\
\hline$A 4-8$ & 30.80 & 22.50 & 4.98 & 27,42 \\
\hline A4-9 & 27.80 & 22.50 & 3.18 & 38.66 \\
\hline
\end{tabular}

C.9 
TABLE C.10. Mass Balance Calculations for Nitrite $\left(\mathrm{NO}_{2}\right)$

STATIC LEACH TEST

\begin{tabular}{|c|c|c|c|c|}
\hline SALPLE NO. & $\begin{array}{l}\text { ERLUeit } \\
\text { pp } \mathrm{NO2}\end{array}$ & $\begin{array}{l}\text { HGI CONC. } \\
\text { ppo NO2 }\end{array}$ & $\begin{array}{l}\text { BUाED } \\
\text { N02 }\end{array}$ & $\begin{array}{c}\text { TOTAL CHANGE } \\
\text { ng NO2 }\end{array}$ \\
\hline$S 1-1$ & 182.00 & 0.36 & 97.42 & 97.12 \\
\hline$\$ 1-2$ & 390.10 & 0.36 & 144.80 & 241.81 \\
\hline$\$ 1-3$ & 465.00 & 0.31 & 84.48 & 398.39 \\
\hline \$1-4 & 540.09 & 0.30 & 68.23 & 374.62 \\
\hline SAIPLE NO. & $\begin{array}{l}\text { GFLUEYT } \\
\text { gpm N02 }\end{array}$ & $\begin{array}{l}\text { HG. CONC. } \\
\text { ppe NO2 }\end{array}$ & $\begin{array}{l}\text { EUTED } \\
\text { O ND2 }\end{array}$ & $\begin{array}{c}\text { TOTAL CHANCE } \\
\text { og } \mathrm{K02}\end{array}$ \\
\hline \$2-1 & 215.41 & 0.36 & 128.82 & $12 B .82$ \\
\hline S2-2 & 355.60 & 0.36 & 94.73 & 223.55 \\
\hline$\$ 2-3$ & 449.10 & 0.35 & 74.13 & 297.89 \\
\hline \$2-4 & 540.10 & 0.30 & 77.83 & 374.72 \\
\hline
\end{tabular}

NS 18.1 LEACH TEST

\begin{tabular}{|c|c|c|c|c|}
\hline SAUPLE NO. & $\begin{array}{l}\text { EFLIET } \\
\text { ppe N02 }\end{array}$ & $\begin{array}{l}\text { HOS CONC. } \\
\text { ppa NO2 }\end{array}$ & $\begin{array}{l}\text { 日UTED } \\
\text { ig N02 }\end{array}$ & 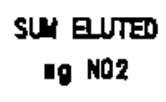 \\
\hline 13-1 & 54.09 & 1.30 & 32.22 & 32.22 \\
\hline A3-2 & 27.39 & 6.30 & 16.20 & 48.42 \\
\hline$A 3-3$ & 51.00 & 6.31 & 34.42 & 78.84 \\
\hline A3-4 & 61.01 & 1.36 & 34.42 & 169.26 \\
\hline$A 3-5$ & 32.90 & 0.30 & 10.58 & 128.82 \\
\hline A3-6 & 25.96 & 0.30 & 15.38 & 144.18 \\
\hline A3-7 & 168.6 & 0.30 & 190.82 & 244.98 \\
\hline A3-8 & 86.06 & 9.30 & 57.42 & 362.22 \\
\hline $13-8$ & 89.60 & 0.39 & 48.30 & 350.5 \\
\hline
\end{tabular}

\begin{tabular}{|c|c|c|c|c|}
\hline SALPLE NO. & $\begin{array}{l}\text { EFLUENT } \\
\text { PPA N02 }\end{array}$ & $\begin{array}{l}\text { HG. CaN. } \\
\text { ppm N02 }\end{array}$ & $\begin{array}{l}\text { 日UUED } \\
\text { Na2 }\end{array}$ & $\begin{array}{l}\text { SW EUTाE } \\
\text { ng N02 }\end{array}$ \\
\hline A4-1 & 85.60 & D. 31 & 38.82 & 38.62 \\
\hline $14-2$ & 24.50 & 1.31 & 14.52 & 53.34 \\
\hline A4-3 & 49. 36 & 0.36 & 24.69 & 77.34 \\
\hline $44-4$ & 40.00 & 0.30 & 28.62 & 195.98 \\
\hline A4-6 & 31.86 & 0.30 & 18.99 & 124.88 \\
\hline A4-8 & 32.50 & 0.30 & 19.32 & 144.18 \\
\hline M-7 & 213.00 & 30 & 127.62 & 271.89 \\
\hline A4-6 & 122.00 & 6.39 & 73.12 & 344.82 \\
\hline A4-9 & 86.76 & 0.30 & 51.84 & 398.68 \\
\hline
\end{tabular}


TABLE C.11. Mass Balance Calculations for Nitrate $\left(\mathrm{NO}_{3}\right)$ STATIC LEACH TEST

\begin{tabular}{|c|c|c|c|c|}
\hline SALPLE NO. & $\begin{array}{l}\text { EFLUET } \\
\text { ppn W03 }\end{array}$ & $\begin{array}{l}\text { HOW CONC. } \\
\text { PpD NOS }\end{array}$ & $\begin{array}{l}\text { EUTा } \\
\text { eg N03 }\end{array}$ & $\begin{array}{c}\text { TOTAL CHANGE } \\
\text { G NOS }\end{array}$ \\
\hline 51-1 & 382.01 & 0.6 & 228.90 & 228.90 \\
\hline $51-2$ & 401.01 & 1.55 & 29.87 & 258.78 \\
\hline S1-3 & 895.4 & 1.56 & 262.97 & 521.75 \\
\hline$\$ 1-4$ & 1210.6 & 9.59 & 283.22 & 894.97 \\
\hline SAIPLE NO. & $\begin{array}{l}\text { EFLUET } \\
\text { PpE NO3 }\end{array}$ & $\begin{array}{l}\text { HOW coll. } \\
\text { ppa NO3 }\end{array}$ & $\begin{array}{l}\text { g.UT } \\
\text { of } \mathrm{N03}\end{array}$ & $\begin{array}{c}\text { TOTAL CHAMGE } \\
\text { @g }\end{array}$ \\
\hline $52-1$ & 585.96 & 5. 50 & 302.70 & 392.70 \\
\hline S2-2 & 370.6 & c. 68 & -55.78 & 246.92 \\
\hline $52-3$ & 1010.69 & 1.69 & 402.47 & 649.40 \\
\hline $52-4$ & 1210.60 & 0.58 & 376.47 & 819.87 \\
\hline
\end{tabular}

ANS 16.1 LEACH TEST

\begin{tabular}{|c|c|c|c|c|}
\hline SAUPLE NO. & $\begin{array}{l}\text { EFLUT } \\
\text { ppa k03 }\end{array}$ & $\begin{array}{l}\text { Hoi caic. } \\
\text { Ppa N03 }\end{array}$ & $\begin{array}{l}\text { 日UTED } \\
\text { g Na3 }\end{array}$ & $\begin{array}{l}\text { SU, BUTED } \\
\text { og } \mathrm{N03}\end{array}$ \\
\hline A3-1 & 121.09 & 0.50 & 72.30 & 72.30 \\
\hline A3-2 & 56.79 & 0.50 & 39.72 & 168.62 \\
\hline 13-3 & 104.60 & 0.50 & 82.10 & 168.12 \\
\hline A3-4 & 104.69 & 0.50 & 82.10 & 230.22 \\
\hline A3- 5 & 65.00 & 0.50 & 38.70 & 288.92 \\
\hline A3-6 & E5. 10 & 6.50 & 32.78 & 361.68 \\
\hline A3-7 & 387.00 & 1.54 & 210.91 & 621.58 \\
\hline$A 3-8$ & 210.09 & 0.50 & 125.70 & 847.28 \\
\hline $3-9$ & 176.00 & 59 & 105.39 & 75258 \\
\hline
\end{tabular}

\begin{tabular}{|c|c|c|c|c|}
\hline SALPLE NO. & $\begin{array}{l}\text { GFLUETT } \\
\text { ppn N03 }\end{array}$ & $\begin{array}{l}\text { HOS CONC. } \\
\text { PPA NO3 }\end{array}$ & $\begin{array}{l}\text { EUTED } \\
\text { mg N03 }\end{array}$ & $\begin{array}{l}\text { SUN EUUTED } \\
\text { ig NO3 }\end{array}$ \\
\hline$A 4-1$ & 160.00 & 9. 50 & 89.70 & 89.76 \\
\hline$A 4-2$ & 54.20 & 0.60 & 32.22 & 121.92 \\
\hline $14-3$ & 98,09 & 0.50 & 53.70 & 175.62 \\
\hline $14-4$ & 195.00 & 1.58 & 62.70 & 238.32 \\
\hline A4-5 & 80.00 & 0.50 & 41.19 & 279.42 \\
\hline $14-8$ & 72.00 & 0.60 & 42.81 & 322.32 \\
\hline $14-7$ & 431.00 & 0.50 & 258.34 & 580.62 \\
\hline A4-8 & 272.00 & 0.60 & 162.90 & 743.52 \\
\hline $14-9$ & 194.00 & 0.58 & 116.10 & 859.62 \\
\hline
\end{tabular}


IABLE C.12. Mass Balance Calculations for Sulfate $\left(\mathrm{SO}_{4}\right)$

STATIC LEACH TEST

\begin{tabular}{|c|c|c|c|c|}
\hline SAMPLE NO. & $\begin{array}{l}\text { EFLUET } \\
\text { ppe s04 }\end{array}$ & $\begin{array}{l}\text { He CONC. } \\
\text { ppa SD4 }\end{array}$ & $\begin{array}{l}\text { BUTED } \\
\text { eg SO4 }\end{array}$ & $\begin{array}{c}\text { TOTAL CHANCE } \\
\text { ng } 504\end{array}$ \\
\hline S1-1 & 118.00 & 70.50 & 29.19 & 29.10 \\
\hline $51-2$ & 235.80 & 76.50 & 72.92 & $\$ 61.12$ \\
\hline $51-3$ & 273.60 & 76.50 & 31.32 & 132.46 \\
\hline $51-4$ & 312.64 & 70.50 & 33.25 & 165.70 \\
\hline SAIPUE NO. & $\begin{array}{l}\text { EFLIETT } \\
\text { ppe SO4 }\end{array}$ & $\begin{array}{l}\text { HOT COIK. } \\
\text { Dpe SO4 }\end{array}$ & $\begin{array}{l}\text { EUTE } \\
\text { mg SO4 }\end{array}$ & $\begin{array}{c}\text { TOTAL CHANOE } \\
\text { eg SO4 }\end{array}$ \\
\hline$\$ 2-1$ & 289.05 & 70.68 & 82.56 & 92.50 \\
\hline $52-2$ & 100.0 & 76.60 & 1.47 & 89.97 \\
\hline $52-3$ & 268.90 & 76.50 & 47.82 & 131.80 \\
\hline $52-4$ & 307.60 & 76.58 & 33.27 & 165.67 \\
\hline
\end{tabular}

ASS 16.1 LEACY TEST

\begin{tabular}{|c|c|c|c|c|}
\hline SAVUE NO. & $\begin{array}{l}\text { EFLUETT } \\
\text { ppa SO4 }\end{array}$ & $\begin{array}{l}\text { HOL cOLC. } \\
\text { ppe SO4 }\end{array}$ & $\begin{array}{l}\text { 日UाED } \\
\text { ig } 504\end{array}$ & $\begin{array}{l}\text { SLA EUTED } \\
\text { ag SOt }\end{array}$ \\
\hline A3-1 & 97.90 & 70.69 & 15.90 & 15.98 \\
\hline A3-2 & 86.20 & 76.50 & 9.42 & 25.32 \\
\hline $13-3$ & 95.08 & 70.50 & $14.7 \mathrm{~g}$ & 40.02 \\
\hline A3-4 & 96.110 & 70.54 & 14.70 & 54.72 \\
\hline AS-5 & 81.05 & 70.50 & 6.84 & 81.56 \\
\hline $13-8$ & 83.00 & 70.60 & 7.50 & 69.86 \\
\hline $13-7$ & 145.00 & 70.5 & 44.70 & 113.78 \\
\hline$A 3-8$ & 119.00 & 70.50 & 29.10 & 142.88 \\
\hline 13-9 & 116.01 & 76.50 & 27.39 & 170.16 \\
\hline
\end{tabular}

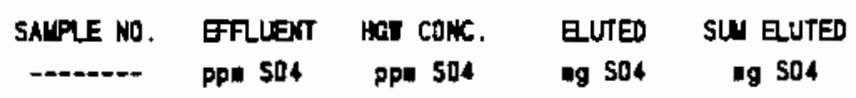

\begin{tabular}{|c|c|c|c|c|}
\hline A4-1 & 103.00 & 70.60 & 19.60 & 19.58 \\
\hline A4-2 & 77.70 & 76.50 & 4.32 & 23.82 \\
\hline A4-3 & 76.46 & 70.50 & 3.54 & 27.38 \\
\hline $14-4$ & 92.00 & 78. ES & 12.96 & 40.28 \\
\hline A4-5 & 82.60 & 70.50 & 6.96 & 47.16 \\
\hline A4-8 & 96.06 & 70.58 & 15.38 & 62.48 \\
\hline $14-7$ & 191.00 & 70.59 & 72.36 & 134.76 \\
\hline $44-8$ & 138.00 & 70.50 & 39.30 & $\$ 74.96$ \\
\hline $14-9$ & 129.60 & 78.56 & 29.78 & 293.78 \\
\hline
\end{tabular}

C. 12 


\section{APPENDIX D}

RAW DATA FOR RADIONUCLIDE COUNTING 
TABLE D.1. Raw Data for Radionuclides

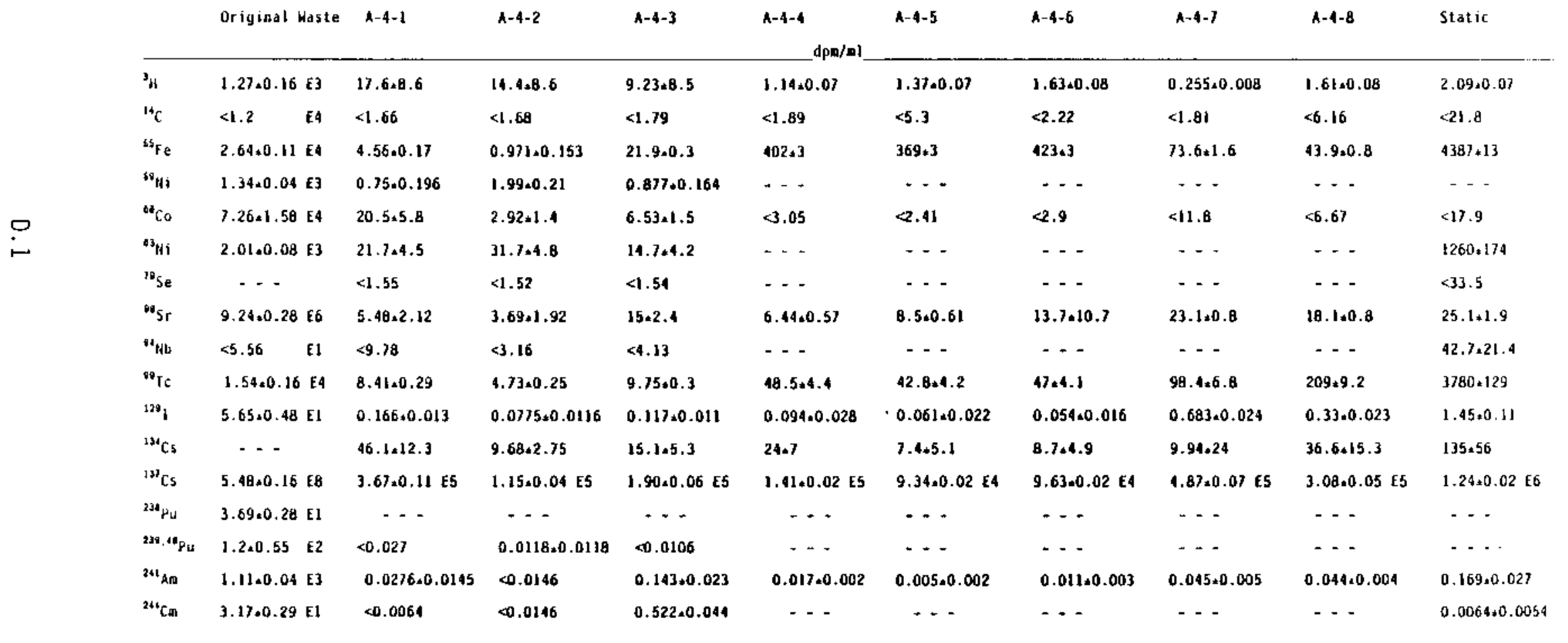


:

.

$+$

$+$ 
APPENDIX E

\section{$\underline{A}_{0}$ (INVENTORY) CALCULATIONS}


TABLE E.1. A Total Inventories for Chemicals and Radioisotopes (includes liquid waste only--no dry blend)

\begin{tabular}{|c|c|c|c|c|}
\hline \multirow[b]{2}{*}{ ELEMENT } & \multicolumn{4}{|c|}{$\mathrm{mg}$} \\
\hline & $S-1$ & $\mathrm{~S}-2$ & $A-3$ & A-4 \\
\hline $\mathrm{Ni}$ & 0.64 & 0.67 & 0.56 & 0.69 \\
\hline B & 0.67 & 0.71 & 0.60 & 0.73 \\
\hline $\mathrm{H}_{3} \mathrm{BO}_{3}$ & 3.83 & 4.06 & 3.43 & 4.18 \\
\hline K & 27.11 & 28.44 & 23.95 & 29.27 \\
\hline Mo & 0.73 & 0.77 & 0.65 & 0.79 \\
\hline $\mathrm{Na}$ & 2211.20 & 2319.54 & 1953.79 & 2387.16 \\
\hline $\mathrm{Cr}$ & 15.61 & 16.37 & 13.79 & 16.85 \\
\hline $\mathrm{F}$ & 3.98 & 4.18 & 3.52 & 4.30 \\
\hline $\mathrm{Cl}$ & 57.47 & 60.29 & 50.78 & 62.05 \\
\hline $\mathrm{NO}_{2}$ & 901.69 & 945.87 & 796.72 & 973.44 \\
\hline $\mathrm{NO}_{3}$ & 2086.48 & 2188.48 & 1843.40 & 2252.27 \\
\hline $\mathrm{SO}_{4}$ & 62.47 & 65.53 & 55.20 & 67.44 \\
\hline
\end{tabular}

\begin{tabular}{|c|c|c|}
\hline ISOTOPE & ANS-4 & STATIC \\
\hline${ }^{88} \mathrm{CO}$ & $8.32 E-01$ & $7.71 \mathrm{E}-01$ \\
\hline${ }^{137} \mathrm{Cs}$ & $6.29 E+03$ & $5.82 E+03$ \\
\hline${ }^{3} \mathrm{H}$ & $1.46 \mathrm{E}-02$ & $1.35 \mathrm{E}-02$ \\
\hline${ }^{59} \mathrm{Ni}$ & $1.54 \mathrm{E}-02$ & $1.42 \mathrm{E}-02$ \\
\hline${ }^{83} \mathrm{Ni}$ & $2.30 \mathrm{E}-01$ & $2.13 E-01$ \\
\hline${ }^{98} \mathrm{Sr}$ & $1.06 \mathrm{E}+02$ & $9.81 E+01$ \\
\hline${ }^{99} \mathrm{Tc}$ & $1.77 \mathrm{E}-01$ & $1.64 \mathrm{E}-01$ \\
\hline${ }^{129} \mathrm{I}$ & $6.49 \mathrm{E}-04$ & $6.01 E-04$ \\
\hline${ }^{241} \mathrm{Am}$ & $1.27 \mathrm{E}-02$ & $1.18 \mathrm{E}-02$ \\
\hline${ }^{244} \mathrm{Cm}$ & $3.64 \mathrm{E}-04$ & $3.37 \mathrm{E}-04$ \\
\hline $238,246 \mathrm{Pu}$ & $1.38 \mathrm{E}-03$ & $1.28 \mathrm{E}-03$ \\
\hline${ }^{238} \mathrm{Pu}$ & $4.22 \mathrm{E}-04$ & $3.91 \mathrm{E}-04$ \\
\hline
\end{tabular}




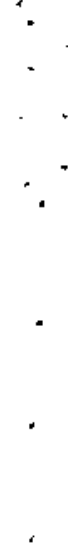




\section{DISTRIBUTION}

No, of

Copies

\section{OFFSITE}

10 DOE/Office of Scientific and Technical Information

J. A. Coleman, NE-24

DOE Office of Remedial

Action and Waste Technology

19901 Germantown Road

Germantown, MD 20545

M. W. Frei

Office of Geologic Repositories

Department of Energy, OCRWM

Forrestal Building

1000 Independence Ave., SW

Washington, DC 20585

3 DOE Office of Defense Haste and Transportation Management 19901 Germantown Road Germantown, MD 20545

ATTN: T. C. Chee, DP-123

G. H. Daly, DP-I23

J. E. Lytle, DP-12

J. C. Haugen

DOE Chicago Operations office

9800 South Cass Avenue

Argonne, IL 60439

F. Bazan

Lawrence Livermore National Laboratory

University of California

P.0. Box 808

Livermore, CA 94550

D. E. Clark

University of Florida

Department of Material Science and Engineering

College of Engineering

Gainesville, FL 326Il

\section{Copies}

3 Westinghouse Savannah River Company

Savannah River Site

Aiken, SC 29808-0001

ATTN: C. A. Langton

R. M. Wallace

E. Wilhite

T. C. Johnson

Nuclear Regulatory Commission MS-623SS

Washington, D.C. 20555

P. B. Macedo

Vitreous State University

Keane Hall

Catholic University of America

P.0. Box 1663

Wastington, DC 20064

M. McFadden

DOE Albuquerque Operations office

P.0. Box 5400

Albuquerque, NM 87115

R. M. Neilson, Jr.

EG\&G

P.0. Box 1625

Idaho Falls, ID 83415

3 Brookhaven National Laboratory Upton, NY 11973

ATTN: M. Fuhrmann

R. F. Pjetrzak

T. M. Sullivan

4 Oak Ridge National Laboratory

P.0. Box X

0ak Ridge, TN 37831

ATTN: T. M. Gilliam

H. W. Godbee

E. McDaniel

T. L. Sams 
No. of

Copies

E. B. Peacock

Wastech, Inc.

P.0. Box 1213

Oak Ridge, TN 37831-1213

J. M. Pope

West Valley Nuclear Services Co.

P.0. Box 1910

West Valley, NY 14171

D. Roy

Pennsyivania State University

University Park, PA 16802

D. M. Smith

University of New Mexico

Chemical and Nuclear

Engineering Department

Albuquerque, NM 87131

\section{FOREIGN}

\section{A. Atkinson \\ Atomic Energy Research \\ Est abl i shment \\ HARWELL \\ Didcot \\ Oxfordshire, OX 11 ORA \\ UNITED KINGDOM}

\section{P. Buckley \\ Atomic Energy of Canada Ltd. \\ Chalk River, Ontario KOJ luo \\ CANADA \\ P. Cote \\ Environment Canada \\ Canada Centre for Inland Waters \\ Burlington, Ontario LTR 4A6 \\ CANADA}

R. Dayal

Ontario Hydro

800 Kipling Ave.

Toronto, Ontario M8Z $5 S 4$

CANADA
No. of

Copies

C. L. Farmer

Atomic Energy Establishment

WINFRITH

Dorchester, Dorset DT2 8DH

UNITED KINGDOM

\section{$\underline{\text { ONSITE }}$}

5 DOE Richland Operations Office

E. M. Bowers

E. A. Bracken

G. J. Bracken

C. Collantes

R. J. Nevarez

17 Westinghouse Hanford Company

J. M. Allison

T. B. Bergman

L. C. Brown

C. Defigh-Price

D. W. Hendrickson (10)

W. G. Richmond

J. E. Van Beek

G. F. Williamson

52 Pacific Northwest Laboratory

K. A. Borgeson

J. L. Conca

L. J. Criscenti

J. W. Falco

G. W. Gee

J. M. Hales

P. C. Hays

T. L. Jones

D. A. Lamar

D. L. Lane

V. L. Legore

C. W. Lindenmeier

R. 0. Lokken (5)

P. F. C. Martín

W. J. Martin

G. W. McNair

J. E. Mende? 
No. of

Copies

D. H. Mitche11 (5)

P. F. Salter

R. J. Serne (15)

D. R. Sherwood

R. L. Skaggs

G. A. Whyatt

R. E. Wildung

Publishing Coordination

Technical Report Files (5) 


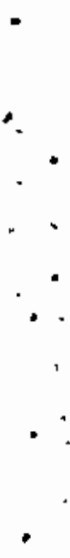

, 